UNIVERSIDADE DE SÃO PAULO

FACULDADE DE ZOOTECNIA E ENGENHARIA DE ALIMENTOS

PROGRAMA DE PÓS-GRADUAÇÃO EM ENGENHARIA E CIÊNCIA DE MATERIAIS

André Diniz Rosa da Silva

OBTENÇÃO DE CERÂMICAS POROSAS DE ALUMINA-ZIRCÔNIA PELO MÉTODO DA RÉPLICA RECOBERTAS COM FOSFATO DE CÁLCIO 



\title{
OBTENÇÃO DE CERÂMICAS POROSAS DE ALUMINA-ZIRCÔNIA PELO MÉTODO DA RÉPLICA RECOBERTAS COM FOSFATO DE CÁLCIO
}

\author{
VERSÃO CORRIGIDA
}

\begin{abstract}
Tese apresentada à Faculdade de Zootecnia e Engenharia de Alimentos da Universidade de São Paulo, Programa de Pós-Graduação em Engenharia e Ciências de Materiais, como parte dos requisitos para a obtenção do título de Doutor em Ciências.
\end{abstract}

Área de concentração: Desenvolvimento, Caracterização e Aplicação de Materiais Voltados à Agroindústria

Orientadora: Profa Dra.Elíria M. J. Agnolon Pallone Co-orientador: Prof $^{\circ}$ Dr. Anderson de Oliveira Lobo 
Ficha catalográfica elaborada pelo Serviço de Biblioteca e Informação, FZEA/USP, com os dados fornecidos pelo(a) autor(a)

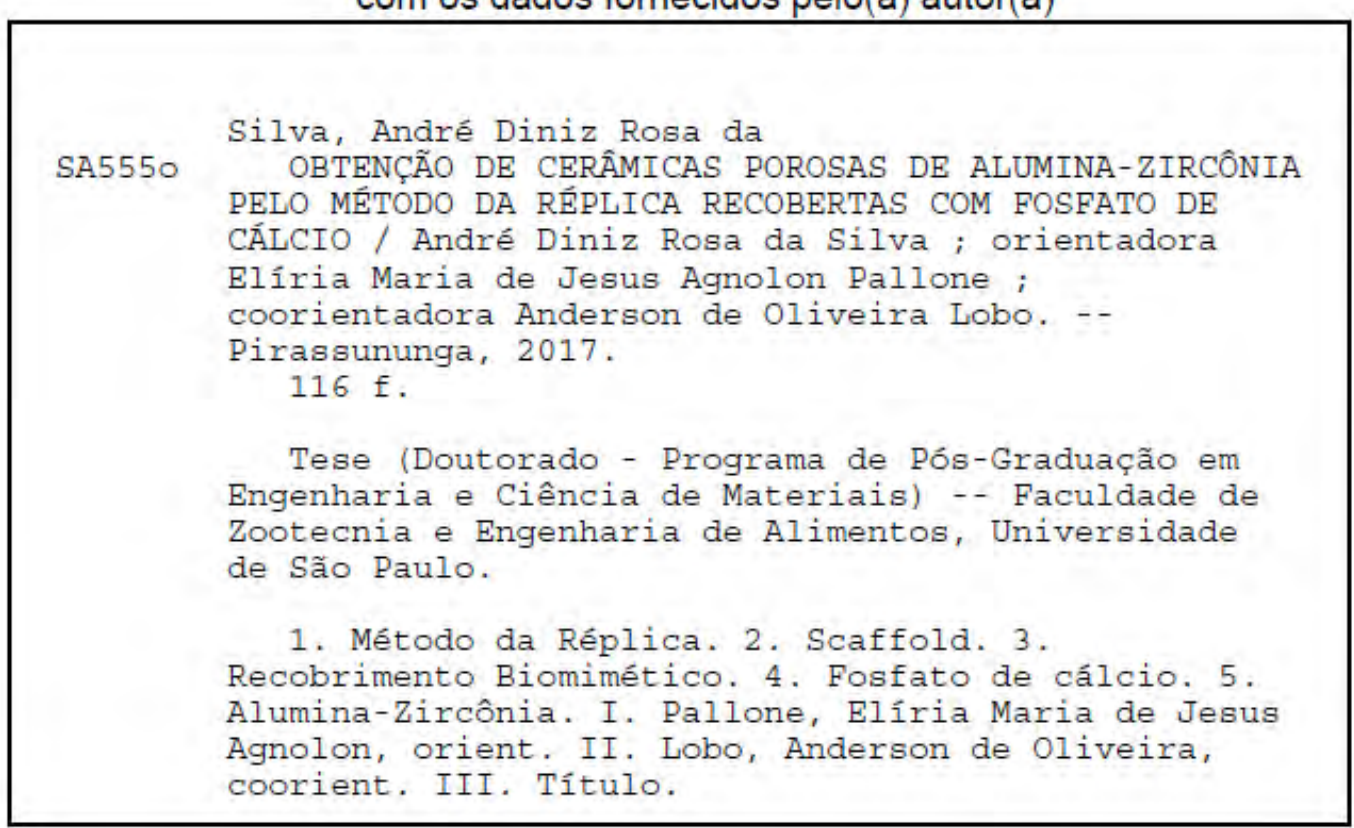

Permitida a cópia total ou parcial deste documento, desde que citada a fonte - o autor 
Banca Examinadora:

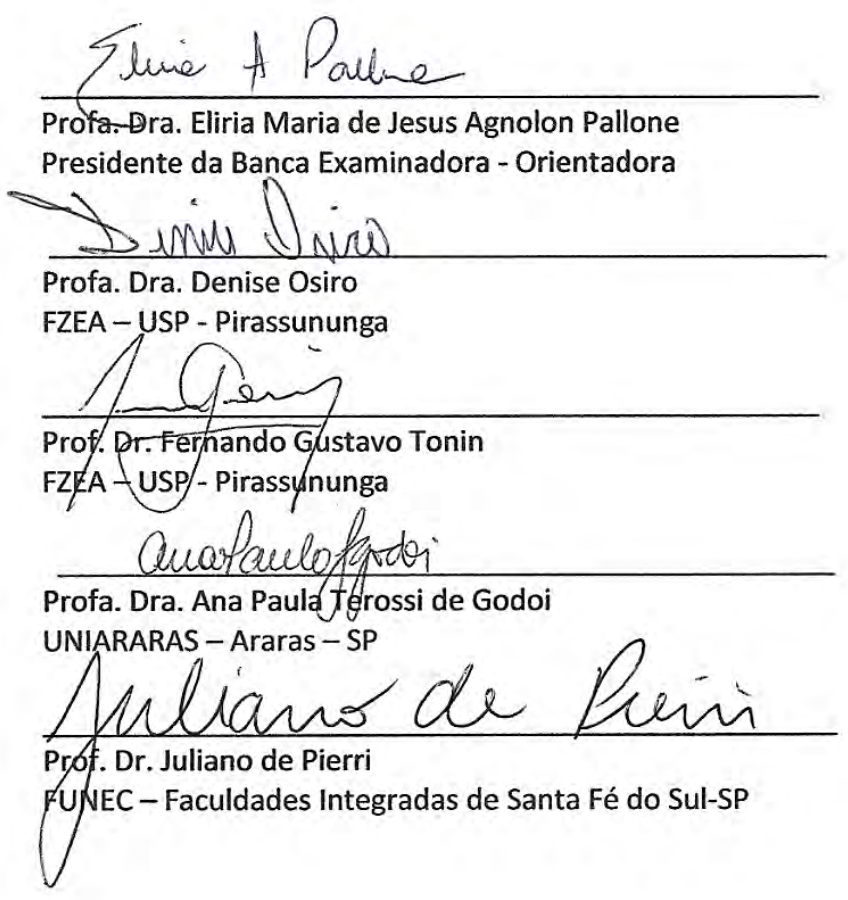


Dedico essa Tese ao grande Químico e eterno amigo Nelson Henriques (in memoriam) que, sempre me incentivou para a evolução e conclusão desse trabalho. 


\section{Agradecimentos}

Agradeço:

Primeiramente à Deus por me dar todas essas oportunidades nessa vida e proporcional a minha capacidade de desenvolvimento moral e intelectual.

Aos meus pais, João e Sônia, e irmãos Joana e João, pela incentivo e compreensão de todas minhas ausências durante esse período.

À minha esposa, Maria Amélia, pelos sentimentos de amor, companheirismo, amizade, compreensão e incentivo em todas etapas do doutorado, pois, sem você não chegaria até o final.

A minha orientadora profa. Dra. Elíria M. J. Agnolon Pallone que, pacientemente e com toda sua disponibilidade propôs o desenvolvimento desse trabalho com dedicação.

Ao meu co-orientador Anderson de Oliveira Lobo que, valorizou e inovou de uma maneira ímpar nosso trabalho.

Aos meus amigos e técnicos do laboratório Constramb e todos que conheci na USP de Pirassununga durante esse período. Obrigado pelo suporte e apoio de todos os dias.

Ao prof. Márcio Morelli, por me ajudar na análise da composição utilizada na produção das cerâmicas porosas.

À profa. Dra. Luana Marota de Vasconcellos e sua equipe pelos testes biológicos realizados em seu grupo de pesquisa.

À profa. Dra. Denise Osiro pelos ensaios de NIR e UCT realizados na EMBRAPA.

À USP pela formação em nível de doutorado.

À CAPES pelo apoio financeiro parcial. 
SILVA, A.D.R.; Obtenção de cerâmicas porosas de alumina-zircônia pelo método da réplica recobertas com fosfato de cálcio, 2017. 119f. TESE (Doutorado em Engenharia e Ciência de Materiais) - Faculdade de Zootecnia e Engenharia de Alimentos, Universidade de São Paulo, Pirassununga, SP, 2017.

\section{Resumo}

As cerâmicas porosas empregadas na substituição óssea, são utilizadas por apresentarem características como biocompatibilidade, ter estrutura tridimensional e apresentar alta porosidade. Nesse sentido, o objetivo desse trabalho foi obter e caracterizar cerâmicas porosas de $\mathrm{Al}_{2} \mathrm{O}_{3}$ e $\mathrm{Al}_{2} \mathrm{O}_{3}$ contendo $5 \%$ em volume de inclusões de $\mathrm{ZrO}_{2}$, produzidas pelo método da réplica. Essas cerâmicas porosas tiveram sua superfície tratada quimicamente com ácido fosfórico e foram recobertos, com fosfato de cálcio usando o método biomimético, em solução de SBF 5X (Simulated Body Fluid) por um período de incubação de 14 dias. Após o recobrimento, algumas cerâmicas porosas foram tratadas quimicamente para incorporação do $\mathrm{Sr}^{2+}$. $\mathrm{Em}$ seguida foram caracterizadas morfologicamente e estruturalmente usando ensaios de compressão axial, porosidade aparente, microscopia eletrônica de varredura (MEV), microtomografia de Raio X ( $\mu-C T)$, difratometria de Raio X (DRX), Espectroscopia de Infravermelho Próximo (NIR), emissão óptica com plasma indutivamente acoplado (ICP-OES), Energia Dispersiva de Raio-X (EDS) e por Ensaios biológicos utilizando cultura de células para análise de viabilidade celular. As cerâmicas porosas de alumina e alumina-zircônia apresentaram, respectivamente, porosidade aparente de 80,93 \% e 78,82 \%, resistência à compressão axial, 2,93 MPa e 6,59 MPa, além de uma ampla faixa de tamanho de poros de, desejáveis para o favorecimento de interesses biológicos destinados à regeneração e formação de tecido ósseo. O recobrimento biomimético usando SBF 5X produziu a formação das fases $\alpha$-TCP, $\beta$-TCP, TTCP e Hidroxiapatita, usando período de incubação de 14 dias. A incorporação de $\mathrm{Sr}^{2+}$ na estrutura dos fosfatos mostrou-se mais eficientes nos corpos porosos de aluminazircônia. Os ensaios in vitro mostraram a biocompatibilidade das cerâmicas porosas estudadas, demonstrando a possibilidade de sua utilização como material para substituição ou preenchimento ósseo.

Palavras-chaves: Método da réplica; Scaffolds; Fosfato de cálcio; Recobrimento biomimético; Alumina-zircônia. 
SILVA, A.D.R.; Obtaining porous alumina-zirconia ceramics by the calcium phosphate-coated replica method, 2017. 119f. TESE (Doctor in Engineering Materials and Science) - Faculty of Animal Science and Food Engineering, University of São Paulo, Pirassununga, SP, 2017.

\begin{abstract}
The porous ceramics used in bone substitution are used because they present characteristics as biocompatibility, have a three - dimensional structure and have high porosity. In this sense, the objective of this work was to obtain and characterize porous ceramics of $\mathrm{Al}_{2} \mathrm{O}_{3}$ and $\mathrm{Al}_{2} \mathrm{O}_{3}$ containing $5 \%$ by volume of $\mathrm{ZrO}_{2}$ inclusions, produced by the replica method. These porous ceramics were chemically treated with phosphoric acid and were coated with calcium phosphate using the biomimetic method in 5X SBF solution (Simulated Body Fluid) for a 14 day incubation period. After coating, some porous ceramics were chemically treated for $\mathrm{Sr}^{2+}$ incorporation. They were then characterized morphologically and structurally using axial compression, apparent porosity, scanning electron microscopy (SEM), microtomography ( $\mu-C T), X$-ray diffractometry (XRD), Near Infrared (NIR) Coupled (ICPOES), X-ray Dispersive Energy (EDS) and Biological Assays using cell culture for cell viability analysis. The porous ceramics of alumina and alumina-zirconia showed, respectively, $80.93 \%$ and $78.82 \%$ apparent porosity, axial compression strength, $2.93 \mathrm{MPa}$ and $6.59 \mathrm{MPa}$, as well as a wide range of pore size, desirable for the promotion of biological interests destined to the regeneration and formation of bone tissue. Biomimetic coated using SBF $5 X$ produced the formation of $\alpha$-TCP, $\beta$-TCP, TTCP and Hydroxyapatite phases using a 14-day incubation period. The incorporation of $\mathrm{Sr}^{2+}$ in the phosphate structure proved to be more efficient in porous alumina-zirconia bodies. The in vitro tests showed the biocompatibility of the porous ceramics studied, demonstrating the possibility of their use as material for bone replacement or filling.
\end{abstract}

Keywords: Replica method; Scaffolds; Calcium phosphate; Biomimetic coating; Aluminazirconia. 
Índice de Figuras

FIGURA 1 - REPRESENTAÇÃO NANO E MACROMÉTRICA DO OSSO COM A FORMAÇÃO DE CRISTAIS DE HA E

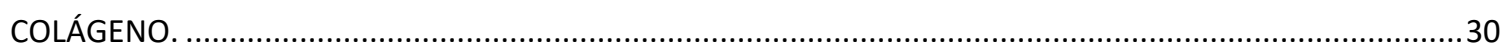

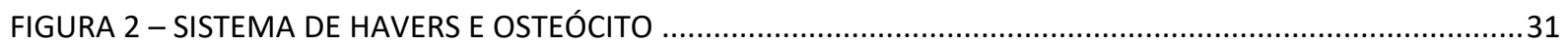

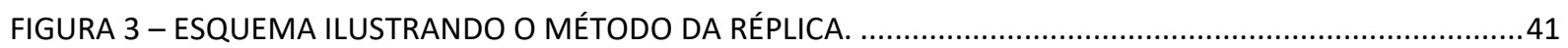

FIGURA 4 - A) IMAGEM DO SCAFFOLD OBTIDO PELO MÉTODO DA RÉPLICA. B) IMAGEM AUMENTADA DESTACANDO AS MICROFISSURAS INTERNAS ENTRE OS FILAMENTOS DOS POROS EM FORMAS DE TRIÂNGULOS VAZIOS

FIGURA 5 - DESENHO ESQUEMÁTICO DA DISSOLUÇÃO PARCIAL/PRECIPITAÇÃO DE APATITAS BIOLÓGICAS IN VIVO E SUBSTITUIÇÕES IÓNICAS NO CRISTAL DE HA (LIU, Q. ET AL., 2013).............................................

FIGURA 6 - FLUXOGRAMA REPRESENTANDO RESUMIDAMENTE AS ETAPAS REALIZADAS NO PROCESSO DE PRODUÇÃO E CARACTERIZAÇÃO DOS CORPOS POROSOS RECOBERTAS COM FOSFATO DE CÁLCIO. ..........51 FIGURA 7 - (A) E (B) - IMAGENS OBTIDAS POR MEV DA ESPONJA UTILIZADA PARA IMPREGNAÇÃO NA BARBOTINA. 55

FIGURA 8 - GRÁFICO REPRESENTANDO AS TAXAS DE AQUECIMENTO X TEMPERATURA ...................................56

FIGURA 9 - REPRESENTAÇÃO ESQUEMÁTICA DAS PASTILHAS DE AÇO FIXADAS NO CORPO ……….....................58 FIGURA 10 - MICROGRAFIAS OBTIDAS POR MEV DA SUPERFÍCIE DE FRATURA DO CORPO POROSO DE ALUMINA MOSTRANDO: (A) E (B) MORFOLOGIA DOS POROS, (C) INTERCONECTIVIDADE, 67 FIGURA 11 - MICROGRAFIAS OBTIDAS POR MEV DA SUPERFÍCIE POLIDA DO CORPO POROSO DE ALUMINA MOSTRANDO: (A) E (B) MORFOLOGIA DOS POROS, (C) INTERCONECTIVIDADE DOS POROS........................68 FIGURA 12 - (A) MICROGRAFIAS OBTIDAS POR MEV DA SUPERFÍCIE DE FRATURA NOS CORPOS POROSOS DE ALUMINA, (B) MICROGRAFIA COM AUMENTO DESTACANDO O AUMENTO COM SUA INTERCONECTIVIDADE E OS VAZIOS TRIANGULARES

FIGURA 13 - MICROGRAFIAS OBTIDAS POR MEV DA SUPERFÍCIE DE FRATURA DO CORPO POROSO DE ALUMINAZIRCÔNIA MOSTRANDO: (A) E (B) MORFOLOGIA DOS POROS, (C) INTERCONECTIVIDADE DOS POROS. ...70 FIGURA 14 - MICROGRAFIAS OBTIDAS POR MEV DA SUPERFÍCIE POLIDA DO CORPO POROSO DE ALUMINAZIRCÔNIA MOSTRANDO: (A) E (B) MORFOLOGIA DOS POROS, (C) INTERCONECTIVIDADE DOS POROS. ....71 FIGURA 15 - (A) MICROGRAFIAS OBTIDAS POR MEV DA SUPERFÍCIE DE FRATURA DO CORPOS POROSOS DE ALUMINA-ZIRCÔNIA. (B) MICROGRAFIA COM AUMENTO DESTACANDO A INTERCONECTIVIDADE E OS VAZIOS TRIANGULARES

FIGURA 16 - MICROGRAFIAS OBTIDAS POR MEV DESTACANDO O TAMANHO E DISTRIBUIÇÃO DOS GRÃOS DE ALUMINA-ZIRCÔNIA

FIGURA 17 - (A) IMAGEM MICROTOMOGRÁFICA TRIDIMENSIONAL DO CORPO POROSO DE ALUMINA, OBTIDA ATRAVÉS DE MCT. (B) E (C) PERFIL MORFOLÓGICO BIDIMENSIONAIS.

FIGURA 18 - (A) IMAGEM MICROTOMOGRÁFICA TRIDIMENSIONAL DO CORPO POROSO DE ALUMINAZIRCÔNIA, OBTIDA ATRAVÉS DE MCT. (B) E (C) PERFIL MORFOLÓGICO BIDIMENSIONAIS 
FIGURA 19 - GRÁFICO REPRESENTANDO A DISTRIBUIÇÃO DE TAMANHO DE POROS, OBTIDO ATRAVÉS DA $\mu C T$,

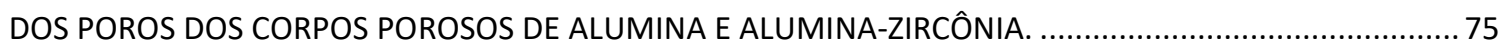

FIGURA 20 - GRÁFICO REPRESENTANDO A MEDIDA DE PH REALIZADA A CADA 48H ….......................................77 FIGURA 21 - ESPECTROS DE ABSORBÂNCIA DE NIR, NA REGIÃO ENTRE 4200 A $5400 \mathrm{CM}^{-1}$, DAS SUPERFÍCIES DOS CORPOS POROSOS DE ALUMINA (A) E COM SUBSTITUIÇÃO IÔNICA (B). .78 FIGURA 22 - ESPECTROS DE ABSORBÂNCIA DE NIR, NA REGIÃO ENTRE 4200 A $5500 \mathrm{CM}^{-1}$, DAS SUPERFÍCIES DOS CORPOS POROSOS DE ALUMINA-ZIRCÔNIA, APÓS TRATAMENTO QUÍMICO (A) E COM SUBSTITUIÇÃO IÔNICA (B).

FIGURA 23 - PERCENTAGEM DE FOSFATOS FORMADOS IDENTIFICADOS ATRAVÉS DOS ESPECTROS DE ABSORÇÃO DE NIR. .83

FIGURA 24 - DIFRATOGRAMAS DE RAIOS-X, DECONVOLUÍDOS, DAS SUPERFÍCIES DOS CORPOS POROSOS DE $\mathrm{AL}_{2} \mathrm{O}_{3}$ (A) E $\mathrm{AL}_{2} \mathrm{O}_{3}-\mathrm{ZRO}_{2}$ (AZ) RECOBERTOS COM FOSFATOS DE CÁLCIO APÓS 14 DE INCUBAÇÃO EM SBF $(5 X)$.

FIGURA 25 - DIFRATOGRAMA DE RAIOS-X, DECONVOLUÍDOS, DA SUPERFÍCIE DOS CORPOS POROSOS DE A(S) RECOBERTOS COM FOSFATOS DE CÁLCIO APÓS 14 DE INCUBAÇÃO EM SBF (5X) E SUBSTITUÍDAS IONICAMENTE PELO SR ${ }^{2+}$ EM DOIS INTERVALOS ENCONTRADOS.

FIGURA 26 - DIFRATOGRAMA DE RAIOS-X, DECONVOLUÍDOS, DA SUPERFÍCIE DOS CORPOS POROSOS DE AZ COM TRATAMENTO SUPERFICIAL, RECOBERTOS COM FOSFATOS DE CÁLCIO APÓS 14 DE INCUBAÇÃO EM SBF (5X) E SUBSTITUÍDAS IONICAMENTE PELO SR ${ }^{2+}$ EM DOIS INTERVALOS ENCONTRADOS. .86

FIGURA 27 - GRÁFICO REPRESENTANDO A PERCENTAGEM DE FASES FORMADAS DE FOSFATO DE CÁLCIO OBTIDAS ATRAVÉS DA TÉCNICA DE DRX.

FIGURA 28 - MICROGRAFIAS OBTIDAS POR MEV DA SUPERFÍCIE DOS CORPOS POROSOS DE ALUMINA RECOBERTAS COM TEMPO DE INCUBAÇÃO DE 7 DIAS. IMAGEM A) DESTACANDO A DISTRIBUIÇÃO DO RECOBRIMENTO B) A DISTRIBUIÇÃO DOS CRISTAIS NO POROS E IMAGEM C) A FORMAÇÃO HOMOGÊNEA DOS CRISTAIS.

FIGURA 29 - MICROGRAFIAS OBTIDAS POR MEV DA SUPERFÍCIE OS CORPOS POROSOS DE ALUMINA RECOBERTAS COM TEMPO DE INCUBAÇÃO DE 14 DIAS. IMAGEM A) DESTACANDO A DISTRIBUIÇÃO DO RECOBRIMENTO B) A DISTRIBUIÇÃO DOS CRISTAIS NO POROS E IMAGEM C) A FORMAÇÃO HOMOGÊNEA DOS CRISTAIS

FIGURA 30 - MICROGRAFIAS OBTIDAS POR MEV DA SUPERFÍCIE OS CORPOS POROSOS DE ALUMINA-ZIRCÔNIA RECOBERTAS COM TEMPO DE INCUBAÇÃO DE 7 DIAS. IMAGEM A) DESTACANDO A DISTRIBUIÇÃO DO RECOBRIMENTO B) A DISTRIBUIÇÃO DOS CRISTAIS NO POROS E IMAGEM C) A FORMAÇÃO HOMOGÊNEA DOS CRISTAIS.

FIGURA 31 - MICROGRAFIAS OBTIDAS POR MEV DA SUPERFÍCIE DOS CORPOS POROSOS DE ALUMINA-ZIRCÔNIA RECOBERTAS COM TEMPO DE INCUBAÇÃO DE 14 DIAS. IMAGEM A) DESTACANDO A DISTRIBUIÇÃO DO RECOBRIMENTO B) A DISTRIBUIÇÃO DOS CRISTAIS E IMAGEM C) A FORMAÇÃO HOMOGÊNEA DOS CRISTAIS. 
FIGURA 32 - MICROGRAFIAS OBTIDAS POR MEV DA SUPERFÍCIE DE FRATURA DOS CORPOS POROSOS APÓSO PERÍODO DE INCUBAÇÃO EM SBF POR 14 DIAS EM A) CORPO POROSO DE ALUMINA E EM B) CORPO POROSO DE ALUMINA-ZIRCÔNIA.

FIGURA 33 - GRÁFICO REPRESENTATIVO DAS PORCENTAGENS MÉDIAS DE ABSORBÂNCIA, OBTIDAS DE VIABILIDADE CELULAR, APÓS CONTATO DAS CÉLULAS COM OS CORPOS POROSOS DE ALUMINA E ALUMINA-ZIRCÔNIA .95

FIGURA 34 - GRÁFICO REPRESENTATIVO DA QUANTIFICAÇÃO DOS NÓDULOS DE MINERALIZAÇÃO DOS CORPOS POROSOS DE ALUMINA E ALUMINA-ZIRCÔNIA.. 96 
Índice de Tabelas

TABELA 1 - REPRESENTAÇÃO DOS PRINCIPAIS COMPOSTOS DE FOSFATO DE CÁLCIO E SUA ..............................32

TABELA 2 - CARACTERÍSTICAS MECÂNICAS DA BIOCERÂMICA DE AL22O $\mathrm{O}_{3}$, COM PUREZA DE..................................35

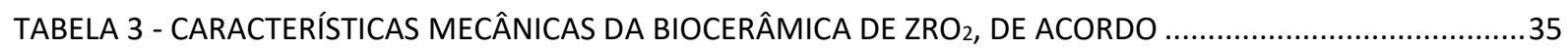

TABELA 4 - COMPOSIÇÃO IÔNICA DO PLASMA SANGUÍNEO E DA SOLUÇÃO DE SBF (MMOL.DM³) .......................44

TABELA 5 - PROPRIEDADES FÍSICAS DOS ELEMENTOS DO GRUPO 2 DA TABELA PERIÓDICA, BIOLOGICAMENTE

IMPORTANTES E SUA DISTRIBUIÇÃO NO CORPO DE UM HOMEM PADRÃO DE 70 KG.................................46

TABELA 6 - REAGENTES UTILIZADOS NA PRODUÇÃO DOS CORPOS DE PROVA POROSOS......................................52

TABELA 7 - COMPOSTOS E SUAS RESPECTIVAS PORCENTAGEM UTILIZADA. ...............................................54

TABELA 8 - REPRESENTAÇÃO DOS COMPONENTES E QUANTIDADES UTILIZADAS PARA A PRODUÇÃO DO SBF

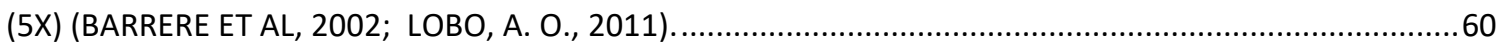

TABELA 9 - TABELA REPRESENTANDO OS PARÂMETROS UTILIZADOS PARA O ENSAIO DE ICP-OES......................61

TABELA 10 - RESULTADOS DOS ENSAIOS DE RETRAÇÃO LINEAR, POROSIDADE APARENTE E RESISTÊNCIA À

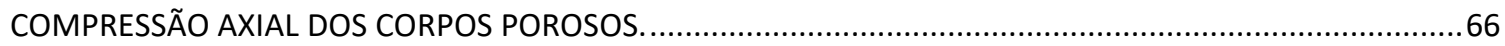

TABELA 11 - FREQUÊNCIA RELATIVA DE POROS DOS CORPOS POROSOS DE AL E AL-ZR REPRESENTADA PELA

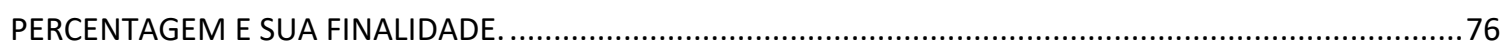

TABELA 12 - POROSIDADE APARENTE (\%) DOS CORPOS POROSOS DE ALUMINA E ALUMINA-ZIRCÔNIA

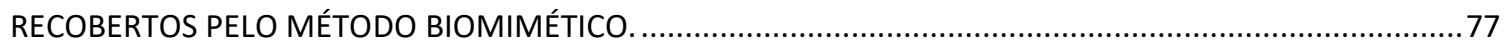

TABELA 13 - ÁREA PERCENTUAL SOB AS CURVAS DE DECONVOLUÇÃO REFERENTES ÀS BANDAS DE COMBINAÇÃO DOS ESPECTROS DE NIR DAS SUPERFÍCIES DOS CORPOS POROSOS DE A E AZ ......................80

TABELA 14 - ÁREA PERCENTUAL SOB AS CURVAS DE DECONVOLUÇÃO REFERENTES ÀS BANDAS DE COMBINAÇÃO DOS ESPECTROS DE NIR DAS SUPERFÍCIES DOS CORPOS POROSOS DE AL2O E ZROO2-AL2 $\mathrm{O}_{3}$ TRATADOS BIOMIMETICAMENTE E OS GRUPOS DE PO $4^{-3}$ FORMADOS NA SUPERFÍCIE DOS RECOBRIMENTOS.

TABELA 15 - RELAÇÃO DAS FASES ENCONTRADAS PARA CADA CORPO POROSO, SUAS REFERÊNCIAS

CRISTALOGRÁFICAS E A PORCENTAGEM ENCONTRADAS ATRAVÉS DA TÉCNICA DE DIFRATOMETRIA DE RAIO-X.

TABELA 16 - RAZÃO CA/P E (CA+SR)/P DOS CORPOS POROSOS RECOBERTOS, REALIZADA POR ICP-OES ...........90 TABELA 17 - RELAÇÃO CA/P DOS CORPOS POROSOS DE ALUMINA E ALUMINA-ZIRCÔNIA USANDO A TÉCNICA DE EDS, PARA TODOS OS PERÍODOS DE INCUBAÇÃO DE 7, 14 E 21 DIAS. ....................................................94

TABELA 18 - RELAÇÃO DOS CORPOS POROSOS DE ALUMINA E ALUMINA-ZIRCÔNIA, MEDIDOS ATRAVÉS DA TÉCNICA DE EDS, PARA TODOS OS PERÍODOS DE INCUBAÇÃO.

TABELA 19 - REAGENTES UTILIZADOS, COMO TESTE, NA PRODUÇÃO DOS CORPOS DE PROVA POROSOS DA FASE

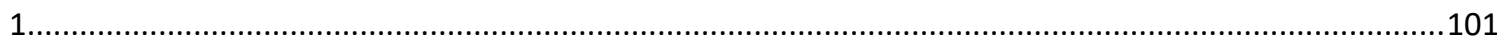

TABELA 20- REAGENTES UTILIZADOS, COMO TESTE, NA PRODUÇÃO DOS CORPOS DE PROVA POROSOS DA FASE 2. 
Lista de Símbolos

HA - Hidroxiapatita - $\mathrm{Ca}_{10}\left(\mathrm{PO}_{4}\right)_{6}(\mathrm{OH})_{2}$

$\boldsymbol{\alpha}, \boldsymbol{\beta}, \boldsymbol{x}$ - fases do fosfato tricálcio (TCP)

$\alpha-\mathrm{Al}_{2} \mathrm{O}_{3}$ - óxido de alumina na fase $\alpha$

$\mathrm{ZrO}_{2}$ - óxido de zircônia

SBF - Simulated Body Fluid (fluido corpóreo simulado)

SBF 5X - SBF cinco vezes mais concentrado

ZnO - óxido de zinco

MgO - óxido de magnésio

$\mathrm{Sr}\left(\mathrm{NO}_{3}\right)_{2}-$ Nitrato de Estrôncio

$\mathrm{H}_{3} \mathrm{PO}_{4}$ - ácido fosfórico

$\mu \mathrm{m}$ - micrômetro $-10^{-6}$

$\mathrm{nm}$ - nano metro $-10^{-9}$

$\mathrm{Ca} / \mathrm{P}$ - razão cálcio fósforo

MPa - Mega Pascal

HV - Hard Vickers

\% wt - porcentagem peso

$\%$ mol - porcentagem moles

$\%$ vol - porcentagem em Volume

ppi - poros por polegada linear

CMC - carboximetil celulose sódica

$\mathrm{mol} / \mathrm{L}$ - moles por litros

$\mathrm{Ca}^{2+}$ - íons de cálcio

$\mathrm{Sr}^{2+}-$ íons de estrôncio

A - Corpos porosos cerâmicos de $\mathrm{Al}_{2} \mathrm{O}_{3}$

$\mathbf{A Z}$ - Corpos porosos cerâmicos de $\mathrm{Al}_{2} \mathrm{O}_{3}$ contendo 5 \%vol de inclusões de $\mathrm{ZnO}$

A-T - Corpos porosos cerâmicos de $\mathrm{Al}_{2} \mathrm{O}_{3}$ e tratados quimicamente com $\mathrm{H}_{3} \mathrm{PO}_{4}$

AZ-T - Corpos porosos cerâmicos de $\mathrm{Al}_{2} \mathrm{O}_{3}$ contendo 5 \%vol de inclusões de $\mathrm{ZnO}$

$A(S)$ - Corpos porosos cerâmicos de $\mathrm{Al}_{2} \mathrm{O}_{3}$, tratados quimicamente com $\mathrm{H}_{3} \mathrm{PO}_{4}$ e recobertas pelo método biomimético e tratadas em solução com Nitrato de Estrôncio $\left(\operatorname{Sr}\left(\mathrm{NO}_{3}\right)_{2}\right)$ 
AZ(S) - Corpos porosos cerâmicos de $\mathrm{Al}_{2} \mathrm{O}_{3}$ contendo 5 \%vol de inclusões de $\mathrm{ZnO}$, tratados quimicamente com $\mathrm{H}_{3} \mathrm{PO}_{4}$, recobertas pelo método biomimético e tratadas em solução com Nitrato de Estrôncio $\left(\mathrm{Sr}\left(\mathrm{NO}_{3}\right)_{2}\right)$.

A-T-Rec - Corpos porosos cerâmicos de $\mathrm{Al}_{2} \mathrm{O}_{3}$, tratados quimicamente com $\mathrm{H}_{3} \mathrm{PO}_{4}$ e recobertas pelo método biomimético

AZ-T-Rec - Corpos porosos cerâmicos de $\mathrm{Al}_{2} \mathrm{O}_{3}$ contendo 5 \%vol de inclusões de $\mathrm{ZnO}$, tratados quimicamente com $\mathrm{H}_{3} \mathrm{PO}_{4}$ e recobertas pelo método biomimético

$\mu \mathrm{CT}$ - Microtomografia Computadorizada de Raios X 


\section{Sumário}

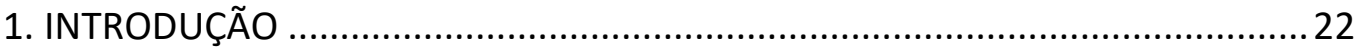

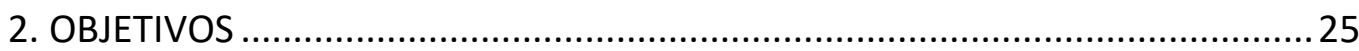

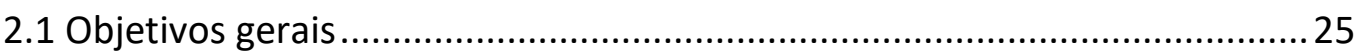

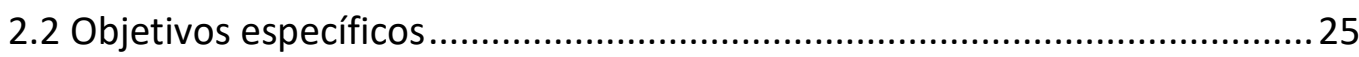

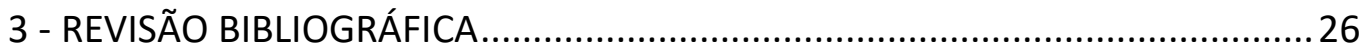

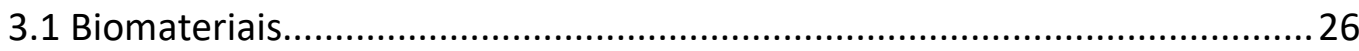

3.2 Classificação dos biomateriais quanto à resposta biológica ..........................27

3.2 Biomateriais usados na substituição óssea................................................2 28

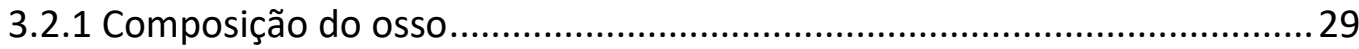

3.2.2 Biocerâmicas de Fosfatos de cálcio e suas fases....................................... 31

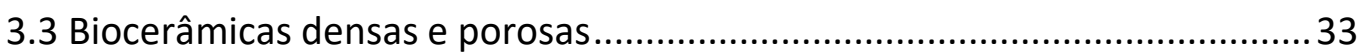

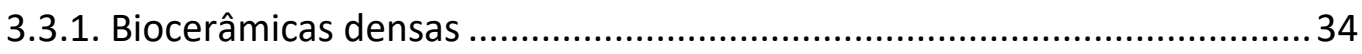

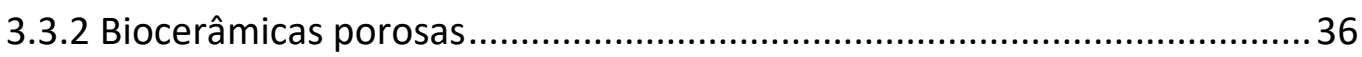

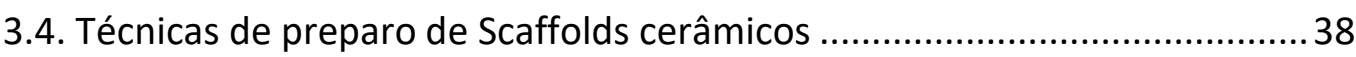

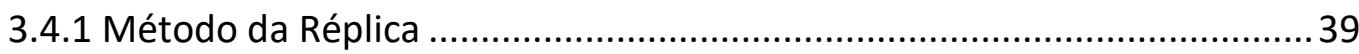

3.5. Tratamento químico superficial em biocerâmicas..................................... 42

3.6 Métodos de recobrimento usando materiais bioativos ............................ 44

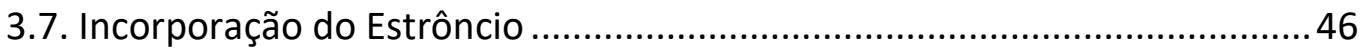

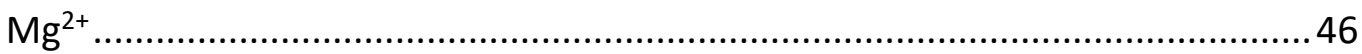

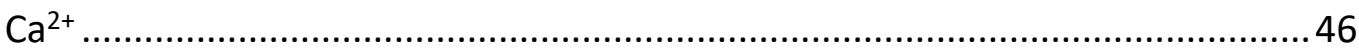

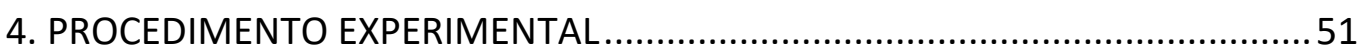

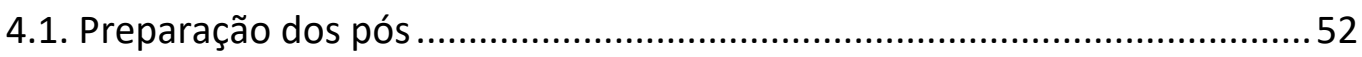

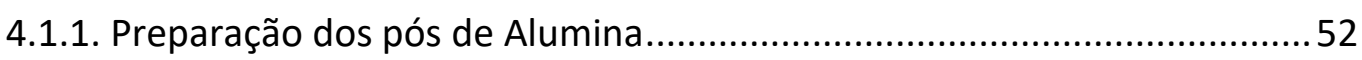

4.1.2. Preparação dos pós de Alumina/Zircônia ................................................53 
4.2. Preparação da barbotina para produção os corpos porosos 53

4.2.1. Preparação dos corpos porosos 55

4.3. Calcinação e sinterização dos corpos porosos de alumina e alumina/zircônia 55

4.4. Caracterização dos corpos porosos ......................................................... 56

4.4.1. Densidade aparente e Porosidade aparente .......................................... 56

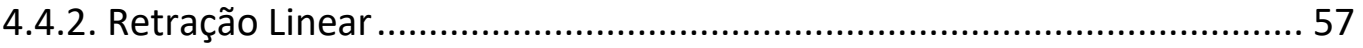

4.4.3. Microscopia Eletrônica de Varredura ................................................... 57

4.4.4. Microtomografia Computadorizada de Raios X ................................... 58

4.4.5. Ensaios de compressão axial ............................................................. 58

4.5. Tratamento químico superficial dos corpos porosos .............................. 59

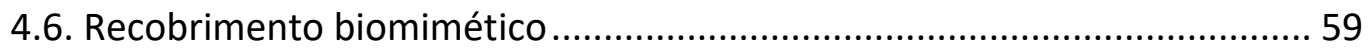

4.7. Incorporação de Estrôncio na camada de fosfatos de cálcio ...................... 60

4.8. Caracterização dos corpos de prova recobertos com fosfatos de cálcio .... 61

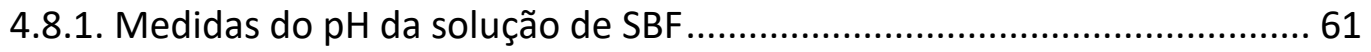

4.8.2. Espectroscopia de emissão óptica com plasma indutivamente acoplado61

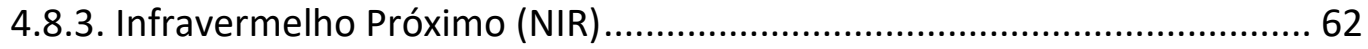

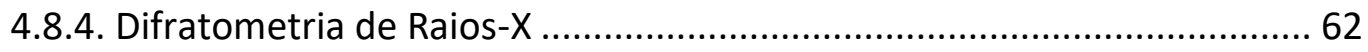

4.8.5. Microscopia eletrônica de varredura ..................................................... 63

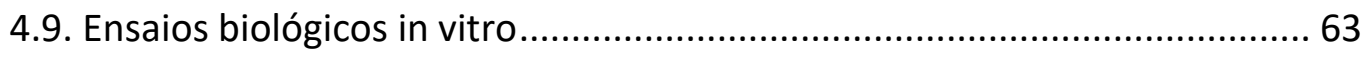

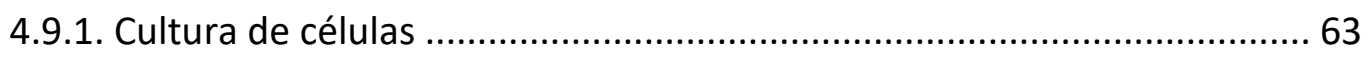

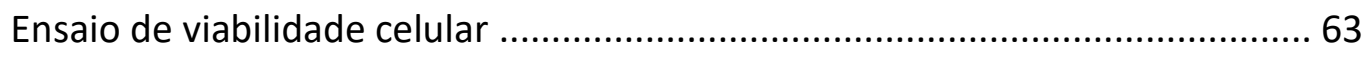

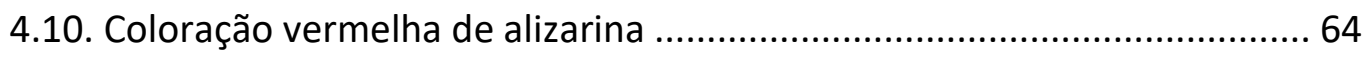

4.11. Formação e quantificação dos nódulos de mineralização ......................... 65

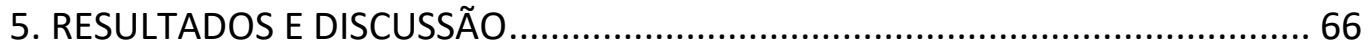

5.1. Caracterização física, microestrutural e mecânica dos corpos porosos ..... 66 
5.2. Corpos porosos recobertas com Fosfatos de Cálcio

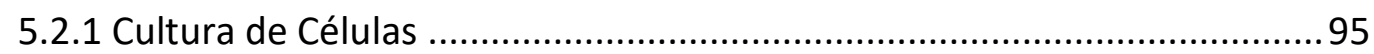

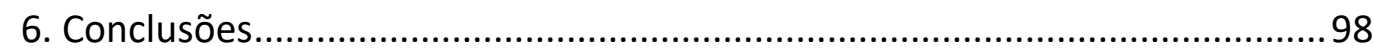

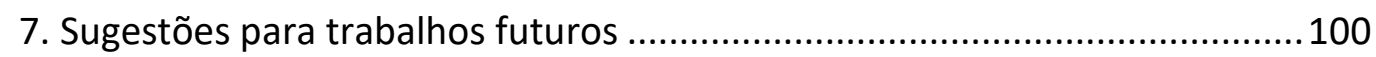

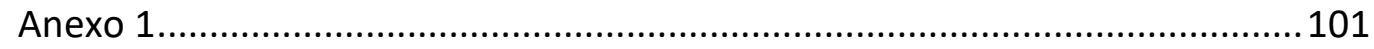

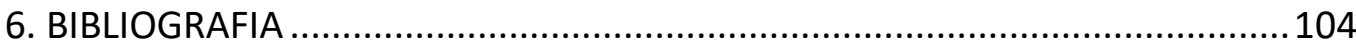




\section{INTRODUÇÃO}

Os biomateriais são utilizados como implantes de forma a substituir ou reparar, parte ou todo, órgão e tecido. Sua utilização tem-se mostrado de extrema importância na melhoria da qualidade de vida das pessoas

Dentre as diversas aplicações dos biomateriais, tem-se a substituição de órgãos e tecidos, sendo os mais decorrentes, aqueles que afetam a estrutura óssea, como a osteoporose, substituição óssea decorrente dos acidentes, entre outros. Nessas intervenções cirúrgicas são substituídos ossos na sua totalidade ou somente parte deles. Nesse contexto, as biocerâmicas são muito estudadas, pois apresentam características próximas aos ossos (HENCH; WILSON, 1993).

As biocerâmicas porosas utilizadas na substituição óssea como estrutura de suporte para formação e reparação, denominadas scaffolds (suportes), são estruturas tridimensionais, porosas que atuam como matrizes temporárias, proporcionando um ambiente e arquitetura específicos para o desenvolvimento e regeneração do tecido ósseo. São utilizados como implantes promovendo adesão e o crescimento celular agindo ainda como um transportador ou modelo para as células ósseas (CROTEAU et al., 1999; FENG et al., 2014; O'BRIEN, 2011). Para que sejam aplicados como implantes, devem apresentar características como biocompatibilidade, porosidade e morfologia de poros adequadas à sua aplicação e elevada área superficial para permitir o crescimento de tecidos. Todas essas características são relevantes para que haja vascularização (SUBIA,2010; FENG et al., 2014; SABREE; GOUGH; DERBY, 2015).

Para produção de scaffolds cerâmicos são utilizados materiais bioinertes que apresentam alta resistência mecânica, pois os materiais bioativos diferentemente, não apresentam tais características (SABREE et al., 2015; SALINAS; VALLET-REGÍ, 2013). Os materiais cerâmicos mais utilizados para essa finalidade são de alumina $\left(\mathrm{Al}_{2} \mathrm{O}_{3}\right)$ e aluminazircônia $\left(\mathrm{Al}_{2} \mathrm{O}_{3}-\mathrm{ZrO}_{2}\right)$, que são bioinertes.

Uma forma de se conseguir um scaffold cerâmico é pelo método da réplica ou método da esponja polimérica. Nesse método há um controle do tamanho e morfologia dos poros através da esponja e da quantidade de aditivos utilizados, onde é possível obter materiais 
altamente porosos, com poros arredondados e interconectados, o que favorece sua aplicação como implante (SABREE et al., 2015).

Os scaffolds cerâmicos bioinertes não apresentam ligação química e nem interação biológica entre o tecido e o implante. Uma alternativa muito utilizada para que ocorra interação biológica na interface implante-tecido é fazer com que ele tenha característica bioativa. Isso pode ser alcançado quando o material é recoberto com um material bioativo, como por exemplo, a hidroxiapatita (HA), material que faz as ligações entre o osso hospedeiro e o implante, permitindo uma eficaz regeneração da parte substituída (SUBIA,2010; SOON et al., 2016).

Nesse contexto novos materiais vêm sendo estudados visando melhorar ainda mais as características mecânicas dos scaffolds bioinertes. Dentre esses materiais, estão o nanocompósitos de matriz de alumina com inclusões nanométricas de zircônia que sob condições fisiológicas, são praticamente inertes, mantendo-se essencialmente inalterados. Esses nanocompóstios são utilizados para otimizar as características mecânica do material produzido. Assim, a adição de fosfatos de cálcio, na forma de recobrimento, faz com que esses biomateriais se tornem bioativos e amplamente reconhecidos com potencial na substituição e restauração de tecidos ósseos (GUIMARAES et al., 2009).

Existem diversos métodos utilizados para o recobrimento de materiais bioinertes, porém um método muito utilizado é o biomimético, sendo muito promissor sob condições ambiente e por recobrir materiais de formas complexas como os materiais porosos. Ele consiste do material em uma solução designada SBF Simulated Body Fluid (fluido corpóreo simulado), a qual tem composição química e pH semelhantes ao plasma sanguíneo ( $\mathrm{ABE}$; KOKUBO; YAMAMURO, 1990).

Além do recobrimento biomimético, pode-se aumentar a bioatividade dos materiais através da adição de componentes químicos no seu recobrimento. Alguns óxidos tem sido mostrado na literatura que podem ser usados com essa finalidade, como o $\mathrm{ZnO}, \mathrm{MgO}$ além de alguns nitratos, como o $\mathrm{Sr}\left(\mathrm{NO}_{3}\right)_{2}$, o qual, vem mostrando-se promissores no aumento da bioatividade e nas características do material a ser implantado (FENG et al., 2014; LI, YUNFENG et al., 2010).

Através dessa discussão, a motivação do decorrente trabalho visa produzir cerâmicas porosas de alumina e alumina-zircônia, tratadas quimicamente com ácido fosfórico $\left(\mathrm{H}_{3} \mathrm{PO}_{4}\right)$, 
visando aumentar a formação da quantidade de fostafos de cálcio formados, além de melhorar a adesão desse recobrimento. Além disso, também pretende estudar a adição de íons de estrôncio após o recobrimento biomimético, visando sua utilização na substituição ou preenchimento ósseo. 


\section{OBJETIVOS}

\subsection{Objetivos gerais}

O objetivo principal deste trabalho é a obtenção e caracterização de biocerâmicas porosas (scaffolds) de alumina e alumina contendo $5 \%$ em volume de inclusões de zircônia, produzidas pelo método da réplica e recobertas com fosfatos de cálcio, visando a sua utilização como implante ósseo.

\subsection{Objetivos específicos}

- Obtenção de corpos porosos de alumina e alumina contendo $5 \%$ vol de inclusões nanométricas de $\mathrm{ZrO}_{2}$ parcialmente estabilizada ( $3 \% \mathrm{~mol}$ ytria), obtidos pelo método da réplica, usando esponja polimérica e sua caracterização física, mecânica e microestrutural;

- Tratamento químico superficial com $\mathrm{H}_{3} \mathrm{PO}_{4}$ dos corpos porosos obtidos;

- Recobrimento superficial dos corpos porosos com fosfatos de cálcio usando solução de SBF 5X (Synthetic Body Fluid- solução semelhantes aos fluidos corpóreos), pelo método biomimético, e adição de íons de estrôncio após o recobrimento;

- Caracterização dos corpos porosos recobertos biomimeticamente;

- Ensaios in vitro para avaliar a biocompatibilidade dos materiais produzidos com a finalidade de implante ósseo. 


\section{3 - REVISÃO BIBLIOGRÁFICA}

\subsection{Biomateriais}

Biomaterial pode ser definido como um material de origem biológica ou sintética, que não seja droga e que apresente propriedades físicas, químicas e biológicas compatíveis com o tecido ósseo, estimulando uma resposta adequada ao meio implantado. São utilizados como implantes, aparelhos ou sistemas de forma a substituir ou reparar, parte ou todo de órgãos e tecidos (KURTZ et al., 2014; MISHIMA et al., 2012; SEPÚLVEDA et al., 1999).

Williams (2009), em seu estudo, abrange considerações baseadas em novas tecnologias, ao afirmar que os biomateriais são definidos como:

"Toda substância projetada para assumir uma forma que, sozinha ou como parte de um sistema complexo, é usada para direcionar, pelo monitoramento de interações com componentes biológicos o curso de qualquer procedimento terapêutico ou de diagnóstico, em medicina humana ou veterinária" (WILLIAMS, 2009).

Esta definição institui em seu sentido mais amplo, que na categoria de biomateriais são enquadrados todos os materiais empregados na Medicina, Odontologia, Medicina Veterinária e Farmacologia (WILLIAMS, 2009).

Os primeiros procedimentos cirúrgicos para implantação de biomateriais, desde à Antiguidade (1000 A.C), quando as grandes civilizações como os assírios, egípcios, gregos, romanos, chineses, maias e astecas, demonstraram interesse na reconstituição estética e funcional de partes do corpo perdidas ou mutiladas, não apresentaram grande sucesso, visto que provocavam respostas infecciosas no organismo do pós-cirúrgico (RATNER et al., 2004).

Em meados de 1860, foi desenvolvida a técnica de cirurgia asséptica e então instaurada a grande evolução no desenvolvimento e na utilização dos biomateriais (PARK; BRONZINO, 2002).

Ao longo dos anos, as aplicações biomédicas envolvendo biomateriais foram projetadas para dispositivos implantáveis de longo prazo, tais como os utilizados na reconstrução ortopédica, odontológica e na substituição de válvulas cardíacas ou vasos sanguíneos (WILLIAMS, 2014). 
Nesse contexto, os biomateriais devem ser isentos de produzir qualquer resposta biológica adversa local ou sistêmica para não causar a perda do implante como reparo ou substituição óssea, ou seja: o material deve apresentar alto potencial clínico sendo não tóxico, não carcinogênico, não antigênico e não mutagênico (MONDAL et al., 2013; STEVENS, 2008). Os materiais utilizados para esse fim podem ser: metálicos, cerâmicos, poliméricos e compósitos.

\subsection{Classificação dos biomateriais quanto à resposta biológica}

Existe uma busca por materiais que tenham resposta ao meio inserido e se comportem de maneira semelhante ou bem próxima dos tecidos vivos. De acordo com esse comportamento os biomateriais são classificados como: bioinertes, biotoleráveis, bioativos e reabsorvíveis (CARVALHO et al., 2010; HENCH; WILSON, 1993; SUBIA, 2010):

i. Materiais bioinertes são aqueles tolerados pelo organismo e não provocavam reações inflamatórias ou infecciosas no local da implantação. Porém, não induzem resposta local do sistema imunológico, tendendo a serem envolvidos por uma camada de tecido fibroso que tendem a isolá-lo dos tecidos adjacentes. Como exemplo de materiais bioinertes, tem-se a alumina $\left(\alpha-\mathrm{Al}_{2} \mathrm{O}_{3}\right)$, zircônia $\left(\mathrm{ZrO}_{2}\right)$ e dióxido de titânio $\left(\mathrm{TiO}_{2}\right)$.

ii. Materiais biotoleráveis são caracterizados pela presença de tecido conjuntivo fibroso entre o implante e o tecido ósseo. Esse tecido fibroso diminui a tolerabilidade dos tecidos ao material. Como exemplo de materiais biotoleráveis tem-se praticamente todos os polímeros sintéticos e a grande maioria dos metais (como o titânio e aço inoxidável).

iii. Materiais bioativos são aqueles que induzem uma resposta específica na interface implante-tecido, permitindo ligação química entre o material e o tecido vivo (osteointegração). A similaridade química do material e a parte mineral óssea permite a ligação entre eles e a osteocondução. Como exemplo de materiais bioativos tem-se a hidroxiapatita, os vidros bioativos e as vitrocerâmicas.

iv. Materiais reabsorvíveis são materiais que após certo período de tempo em contato com os tecidos são degradados, sendo, posteriormente, solubilizados ou fagocitados pelo organismo. Esses materiais não necessitam serem removidos quando implantado. São exemplos desses tipos de materiais os fosfatos tricálcicos ( $\alpha$ e $\beta$ ), ácidos poliláticos e poliglicólicos. 


\subsection{Biomateriais usados na substituição óssea}

A utilização de um biomaterial respeita uma série de requisitos como: biocompatibilidade; biodegradabilidade (fenômeno em que o material é degradado ou solubilizado em fluidos tissulares desaparecendo do sítio de implantação), a biofuncionalidade (capacidade do material implantado desempenhar características mecânicas necessárias pelo tempo programado) e a biocompatibilidade (propriedade de um sistema biológico, não estimular ou estimular minimamente reações adversas possíveis, e tampouco inibir a diferenciação tecidual, característica do local da implantação) (CHEN; LIU, 2016; ORÉFICE; MANSUR, 2006; SANTOS, K. S., 2011) .

Os biomateriais utilizados em enxertos ósseos são classificados conforme sua origem (natural ou sintética) e pela sua composição química, tipos de ligações interatômicas e natureza dos átomos (Silva, 2014).

A regeneração óssea requer quatro componentes essenciais para a sua formação: um sinal morfogenético (estimula o crescimento a diferenciação óssea); células hospedeiras sensíveis que respondam a este sinal; um portador adequado deste sinal que possa envia-los a sítios específicos e um leito hospedeiro vascularizado. Obedecendo a esses requisitos, o biomaterial é desenvolvido para suas necessidades e exigências que surgem (CROTEAU et al., 1999).

Para que ocorra a regeneração óssea através de um enxerto, características como a osteogênese, osteocondução e a osteoindução são funções desejáveis em um implante.

Osteogêneses são materiais capazes de formar osso diretamente a partir de osteoblastos e pelas células que se originam na medula. Um exemplo é o enxerto autógeno (material proveniente de áreas doadoras do próprio indivíduo ao qual será destinado o implante). A osteocondução oferece suporte para o crescimento de capilares, tecido perivascular e células osteoprogenitoras, vindas do leito receptor do hospedeiro na estrutura tridimensional de um implante ou enxerto para formar o osso.

O material osteoindutor é aquele capaz de induzir a transformação de células mesenquimais produzindo células pluripotentes, a partir de um ambiente de não união óssea e de se diferenciar em condrócitos e osteoblastos, com consequente nova formação óssea, sob a influência de um ou mais agentes indutores como as proteínas ósseas morfogenéticas (BMP) entre seus componentes (CARVALHO et al., 2010; COSTA, H S et al., 2008). 


\subsubsection{Composição do osso}

Os ossos são tecidos altamente vascularizados que são remodelados continuamente de acordo com a vida do indivíduo, cumprindo seu papel na locomoção e garantindo sustentação ao esqueleto (CROVACE, 2010). Sua composição principal é formada por fosfatos de cálcio, íons de cálcio e fósforo, representada pela hidroxiapatita $(\mathrm{HA}), \mathrm{Ca}_{10}\left(\mathrm{PO}_{4}\right)_{6}(\mathrm{OH})_{2}$, sendo ela, a principal fase constituinte (cerca de 95\%) (HABRAKEN et al., 2016).

A etapa inicial da produção do osso é a secreção de moléculas de colágeno e de substância fundamental, que é composta por líquido extracelular mais proteoglicanos e ácido hialurônico. Essa secreção é realizada por células chamadas osteoblastos. Os monômeros de colágeno polimerizam-se rapidamente para formar fibras de colágeno onde o tecido resultante transforma-se em osteóide, um material semelhante à cartilagem, mas diferente desta, onde os sais de cálcio se precipitam (COSTA et al., 2008). O colágeno combinado com a HA são responsáveis pelas propriedades mecânicas do osso como a viscoelasticidade (LOBO, A. O., 2011).

Quando o osteóide é formado, alguns dos osteoblastos são aprisionados dentro destes, sendo então chamados de osteócito. Dias após a formação do osteóide, os sais de cálcio começam a se precipitar sobre as superfícies das fibras colágenas, formando diminutos ninhos que se multiplicam rapidamente e crescem, sendo os sais de cálcio precipitados sobre a superfície de colágeno, até o produto final: os cristais de HA (COSTA, H. S. et al., 2008).

Os osteoblastos são células oriundas de células osteoprogenitoras (células-tronco mesenquimais pluripotenciais), sendo uma das principais células responsáveis pela formação ou remodelamento ósseo. Ao decorrer da progressiva síntese da matriz óssea e sua calcificação, os osteoblastos tendem a se isolar e transformam-se em osteócitos, dando prosseguimento a formação do osso maduro (ITÄLÄ et al., 2001).

A Figura 1, representa a formação do osso, o qual tem como principal formador, cristais de HA e moléculas de colágeno de tamanho nanométrico, junto aos osteócitos (PINTO et al., 2013; STEVENS, 2008). 
Figura 1 - Representação nano e macrométrica do osso com a formação de cristais de HA e colágeno.

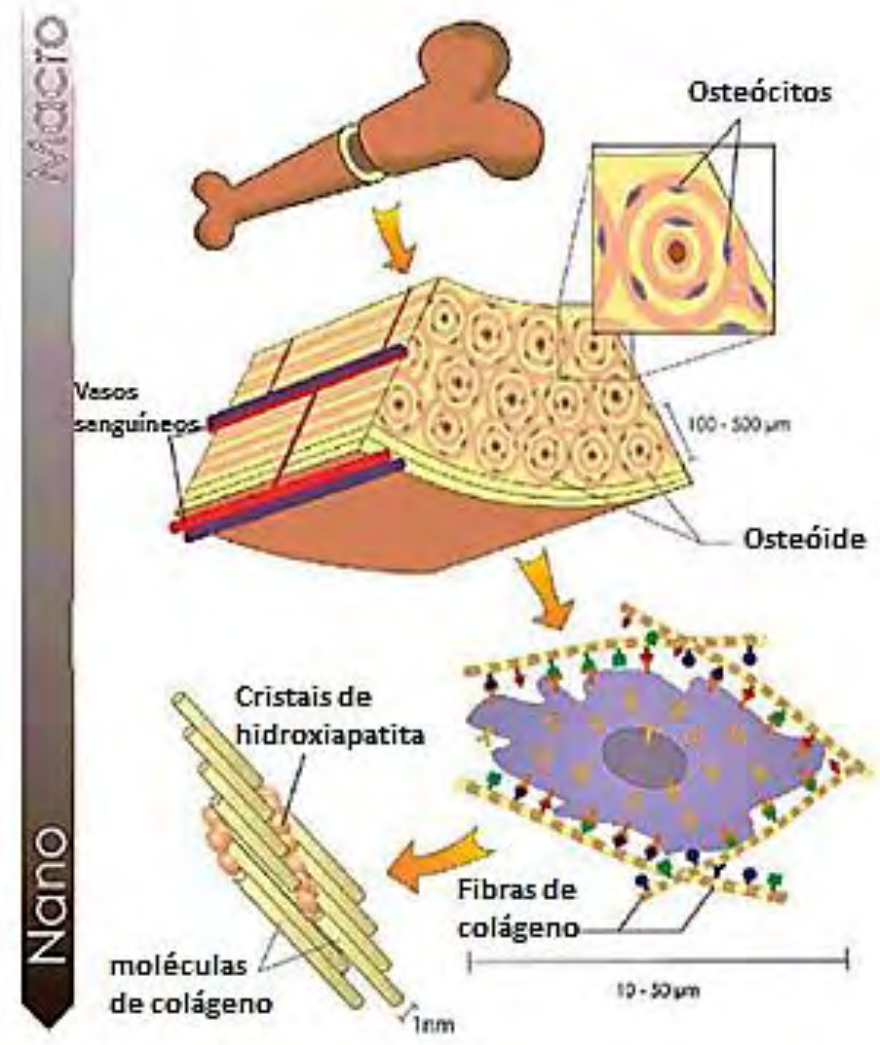

Fonte: (STEVENS, 2008)

O osso é um tecido conectivo formado de colágeno (orgânicos), minerais e água, arranjados em uma distribuição espacial específica. A matriz orgânica do osso é constituída por 90 a 95\% de fibras colágenas. O restante, chamado de substância fundamental, é um meio gelatinoso homogêneo composto por líquido extracelular mais proteoglicanos e ácido hialurônico. Os sais cristalinos depositados na matriz orgânica do osso são constituídos principalmente por fosfatos de cálcio (COSTA et al., 2008; PINTO et al., 2013).

O tecido ósseo primário é a organização das fibras colágenas em lamelas, cuja espessura varia de 3 a $7 \mu \mathrm{m}$ e que se orientam concentricamente ao redor de canais com vasos, formando os sistemas de Havers (osteons). Os canais de Havers comunicam-se entre si, com a cavidade medular e com a superfície externa do osso por meio de canais transversais ou oblíquos, denominados canais de Volkmann, que atravessam as lamelas ósseas. Todos esses canais se formam quando a matriz óssea se forma ao redor de canais preexistentes, como pode-se observar na Figura 2 (JUNQUEIRA; CARNEIRO, 2004). O tecido ósseo possui uma 
alta resistência mecânica, e uma de suas principais funções estão relacionadas à proteção e à sustentação. Funciona como alavanca e apoio para os músculos, aumentando a força do movimento ocasionado pela contração do tecido muscular (FONSECA, 2007).

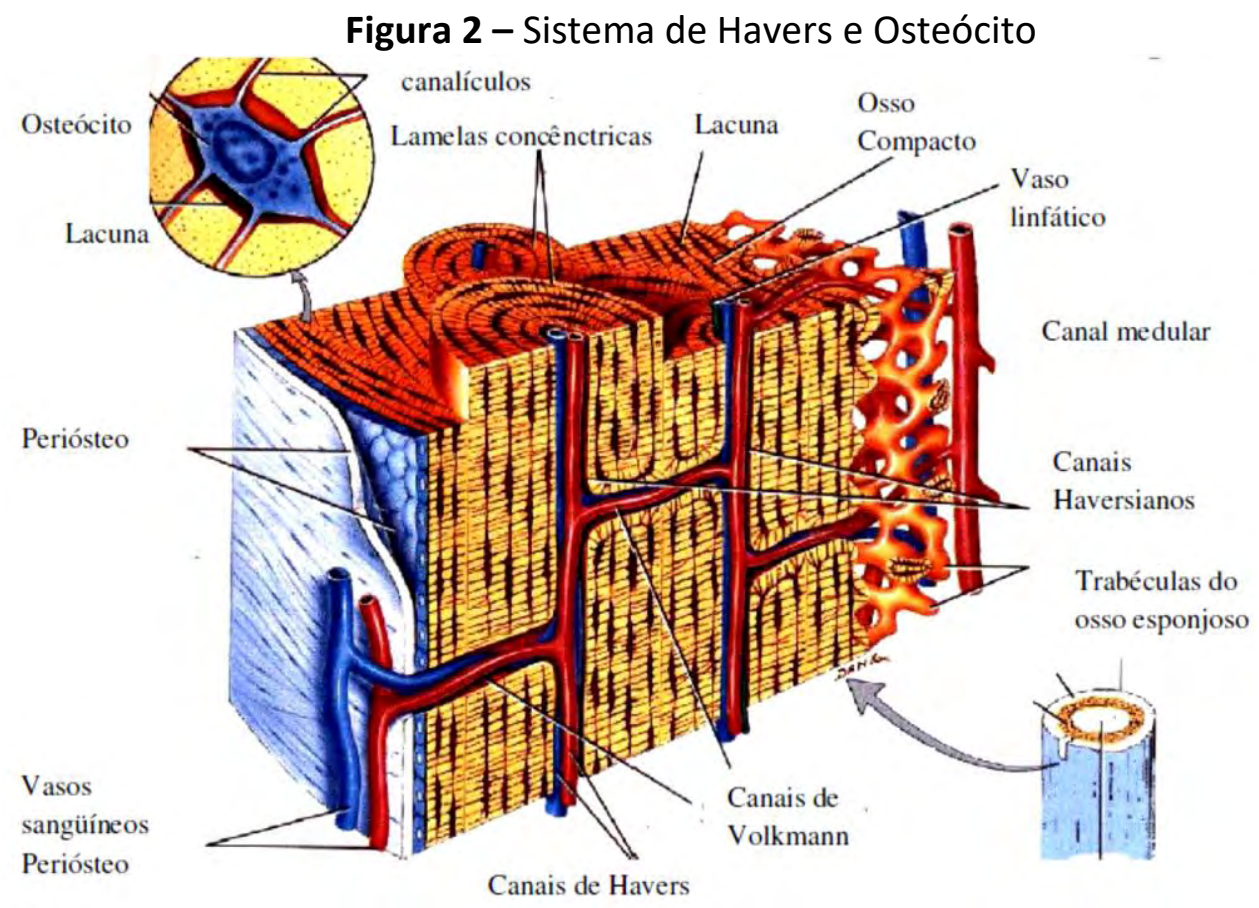

Fonte: (JUNQUEIRA; CARNEIRO, 2004)

\subsubsection{Biocerâmicas de Fosfatos de cálcio e suas fases}

Os fosfatos de cálcio formam basicamente os minerais dos ossos e dentes. As biocerâmicas à base de fosfatos de cálcio permitem participar efetivamente no equilíbrio iônico com o fluído biológico, possibilitando a remodelação óssea no sítio do implante (HABRAKEN et al., 2016).

Como no osso, materiais artificiais bioinertes, podem se ligar aos fosfatos de cálcio, e um requisito essencial para que aconteça essa ligação é a formação de uma camada de fosfato de cálcio na superfície do material in vivo. A diferença entre fosfato de cálcio através dos depositados e o biológica é a quantidade de carbonato que é maior na segunda (BAYRAKTAR; TAŞ, 2000). A HA (uma das fases de fosfato de cálcio) sintética utilizada como implante, possui propriedades de biocompatibilidade e osteointegração, não sendo nocivo ao corpo implantado (LOBO, A. O., 2011).

Os fosfatos de cálcio hidratados é um tipo de HA, sendo os mais estáveis e os menos solúveis de todos constituintes do grupo mineral das apatitas. É encontrado naturalmente nos 
ossos representando de 30 a 70\% de sua massa e dentes. Sua razão cálcio/fósforo (Ca/P) é igual a 1,67 (KAWACHI et al., 2000; ROSA et al., 2000; ZHU et al., 2001).

A razão $\mathrm{Ca} / \mathrm{P}$ determina que, quanto maior a razão, menor será a solubilidade devido a precipitação em meio alcalino, enquanto valores baixos para essa razão, são precipitados em meios ácidos (AOKI, 1991). Esse fato pode ser verificado através do pH dos compostos que, diminui quanto mais solúveis forem (GUASTALDI; APARECIDA, 2010; PAVINATO, 2012).

A Tabela 1 apresenta a classificação dos principais compostos de fosfato de cálcio sintéticos, pela razão $\mathrm{Ca} / \mathrm{P}$ podendo variar de 0,5 a 2,0, sendo esses valores dependentes do método e parâmetro de fabricação (LOBO, A. O., 2011).

Tabela 1 - Representação dos principais compostos de fosfato de cálcio e sua razão $\mathrm{Ca} / \mathrm{P}$.

\begin{tabular}{l|c|c|c}
\hline \multicolumn{1}{c|}{ Composto } & Sigla & Fórmula química & $\mathrm{Ca} / \mathrm{P}$ \\
\hline Hidroxiapatita & $\mathrm{HA}$ & $\mathrm{Ca}_{10}\left(\mathrm{PO}_{4}\right)_{6}(\mathrm{OH})_{2}$ & 1,67 \\
Fosfato tricálcico $(\alpha, \beta, x)$ & $\mathrm{TCP}$ & $\mathrm{Ca}_{3}\left(\mathrm{PO}_{4}\right)_{2}$ & 1,5 \\
Oxiapatita & $\mathrm{OCP}$ & $\mathrm{Ca}_{8} \mathrm{H}_{2}\left(\mathrm{PO}_{4}\right)_{6} 5 \mathrm{H}_{2} \mathrm{O}$ & 1,67 \\
Apatita carbonatada & CA & $\mathrm{Ca}_{10}\left(\mathrm{PO}_{4}\right)_{6} \mathrm{CO}_{3}$ & 1,67 \\
Fosfato tetracálcico & TTCP & $\mathrm{Ca}_{4} \mathrm{P}_{2} \mathrm{O}_{9}$ & 2 \\
Pirofosfato de cálcio & CPP & $\mathrm{Ca}_{2} \mathrm{P}_{2} \mathrm{O}_{7}$ & 1 \\
Metafosfato de cálcio & CMP & $\mathrm{Ca}\left(\mathrm{PO}_{3}\right)_{2}$ & 0,5 \\
\hline
\end{tabular}

Fonte: (HENCH, BEN-NISSAN, 2014; 1998; KALITA; BHARDWAJ; BHATT, 2007).

O grande interesse pelas fases dos fosfatos de cálcio é devido a sua semelhança entre os padrões de difração de raios-X da fase óssea inorgânica e a fase de uma HA carbonatada, encontrada nos ossos (MOURA, 2012).

Algumas fases dos fosfatos de cálcio como a HA e os fosfatos tricálcicos (TCP) são de grande interesse por promoverem calcificações (GUASTALDI; APARECIDA, 2010).

A HA sintética apresenta um grande potencial em implantes ósseos devidos às suas propriedades, como biocompatibilidade, bioatividade e osteointegração. Essa que é a integração (unificação) do tecido ósseo com o material implantado é favorecida pela troca de íons entre o meio fisiológico induz o crescimento ósseo (LAONAPAKUL, 2015; COSTA et al., 
2009; MENDONÇA, 2008). Comparada a outras cerâmicas a base de fosfatos de cálcio, a HA apresenta estabilidade elevada em solução aquosa e formação de cristais maiores.

As hidroxiapatitas são classificadas em dois tipos: as sintetizadas em altas temperaturas, que apresentam boa cristalinidade com cristais grandes e as sintetizadas em baixas temperaturas, que apresentam baixa cristalinidade e cristais pequenos.

Como desvantagem, os fosfatos de cálcio apresentam baixa resistência mecânica, portanto, muito frágeis, não sendo utilizados em regiões do corpo que demandem grande esforço mecânico. Devido a essa desvantagem, são usualmente utilizados em forma de recobrimento de materiais bioinertes. São também utilizados no preenchimento de defeitos e reconstrução óssea, revestimentos de próteses metálicas e transporte de fármacos (DOS SANTOS et al., 2017; GUASTALDI; APARECIDA, 2010).

Os pré-requisitos para a formação das fases de fosfatos de cálcio em forma de camada, são a presença de um grupo químico funcional na superfície, que seja efetivo para nucleação de apatita e um aumento local no grau de supersaturação de apatita no fluido corporal (AFZAL, 2014).

Os fosfatos de cálcio apresentam boas propriedades de estabilidade química superficial, biocompatibilidade e adesão celular, porém, é limitado quando relacionados a suas propriedades mecânicas que são baixas (HE et al., 2008).

\subsection{Biocerâmicas densas e porosas}

Biocerâmicas são materiais de composições cerâmicas com compatibilidade biológica que têm sido descritas como capazes de induzir diferenciação de células medulares nos tecidos circundantes e formação de osso. Exercem mecanicamente de forma eficiente a funcionalidade do tecido que é substituído, podendo ser densa ou porosa.

Algumas propriedades mecânicas, de certas biocerâmicas, são essenciais como: a alta rigidez, baixo coeficiente de atrito e boa resistência ao desgaste (GUIMARAES et al., 2009; THAMARAISELVI; RAJESWARI, 2004).

Uma biocerâmica ideal para um enxerto carece de promover um ambiente para o desenvolvimento dos tecidos. Deve ainda ser esterilizável, sem perda das suas propriedades e não desencadear efeito deletério ao tecido do hospedeiro (BURG; PORTER; KELLAM, 2000; KIDO et al., 2014). 
A utilização de cerâmicas bioinertes vem sendo utilizadas como suporte para o novo tecido ósseo formado, por apresentarem melhores propriedades mecânicas comparadas às cerâmicas de fosfatos de cálcio, e são recobertas com um material bioativo, para ligarem-se quimicamente a estrutura depositada (CROVACE, 2010). Para as biocerâmicas porosas a resistência mecânica à compressão varia de 0,5 a $10 \mathrm{MPa}$, dependendo principalmente da composição porcentagem de porosidade (KWON et al., 2002).

Respostas interfaciais provocadas pelas interações biológicas entre o implante e o tecido receptor e suas características mecânicas são buscadas na biocerâmicas densas e porosas.

As biocerâmicas densas são materiais que provocam pouca ou nenhuma resposta ao corpo implantado e serão descritas com mais detalhes.

\subsubsection{Biocerâmicas densas}

As biocerâmicas bioinertes são materiais que não desenvolvem ligações químicas com o osso, e são na maioria densas. Estão sempre aliadas a boas propriedades mecânica e estética, além disso, exibem pouca ou nenhuma biodegradação quando implantado. Como exemplo, têm-se a alumina e zircônia para substituição e reconstrução das estruturas dentárias, devido às propriedades benéficas, como biocompatibilidade, estabilidade química, propriedades mecânicas, baixa condutividade térmica, alta resistência à abrasão e excelente estética (GUIMARÃES et al., 2009; MCLEAN, 2001; SILVA, 2011).

A alumina apresenta caraterísticas funcionais que favorecem um implante; tem alto potencial para simular a aparência dos dentes naturais, reproduzindo a textura e translucidez bem como possui características mecânicas específicas o que lhe confere a possibilidade de ser aplicada em diversos tipos de próteses (ALVES; STAINER; BERGMANN, 2004; MCLEAN, 2001). Outras características importantes para uma prótese dentária de alumina, é sua alta resistência ao choque térmico.

Além disso, a alumina tem características que favorecem a função de implante como: a biocompatibilidade, a alta resistência ao desgaste, a elevada resistência à corrosão, durabilidade por períodos prolongados, a moderada resistência mecânica, a alta densidade, elevada pureza, elevada dureza, possibilidade de polimento, entre outras (KURTZ et al., 2014). 
Devido as características apresentadas da biocerâmica de alumina, ela é uma forte candidato para substituir o metal nos implantes (GUIMARÃES et al., 2009; MCLEAN, 2001; PIERRI, 2008).

Existem algumas limitações do uso de materiais bioinertes, como a alumina e zircônia, devido ao desenvolvimento de uma membrana fibrosa não aderente, formada entre o material do implante e o tecido hospedeiro, podendo então ocorrer à perda do implante (COSTA et al., 2008).

Algumas características requeridas pelos padrões ASTM, específicos da alumina densa para utilização médica, são resumidas na Tabela 2.

Tabela 2 - Características mecânicas da biocerâmica de $\mathrm{Al}_{2} \mathrm{O}_{3}$, com pureza de 99,5\% wt, de acordo com o padrão.

\begin{tabular}{c|c}
\hline \multicolumn{2}{c}{ Propriedades mecânicas } \\
\hline Densidade (g/cm ${ }^{3}$ ) & 3,98 \\
Resistência à flexão média (MPa) & 400 \\
(mínimo exigido) & \\
Dureza Vickers (HV) & $>2000$ \\
\hline Tenacidade à fratura (MPa/m) & $4-6$ \\
\hline
\end{tabular}

Fonte: (ASTM, 2014b)

A Tabela 3 apresenta algumas características da zircônia, na forma tetragonal policristalina estabilizada por ítria para uso como biomaterial. É normatizada segundo a ISO 13356 (2008).

Tabela 3 - Características mecânicas da biocerâmica de $\mathrm{ZrO}_{2}$, de acordo com o padrão.

\begin{tabular}{c|c}
\hline \multicolumn{2}{c}{ Propriedades mecânicas } \\
\hline Densidade (g/cm ${ }^{3}$ ) & 6,00 \\
$\begin{array}{c}\text { Resistência à flexão média (MPa) } \\
\text { (mínimo exigido) }\end{array}$ & 900 \\
Dureza Vickers (HV) & $>1250$ \\
Tenacidade à fratura (MPa/m) & $4-6$ \\
\hline
\end{tabular}

Fonte: ISO 13356 (2008)

Existe uma necessidade de aumentar as propriedades mecânicas das cerâmicas, dentre elas a resistência à fratura. Isso tem despertado interesse na comunidade científica em 
estudar mecanismos de reforços, dentre eles, estão a adição de inclusões nanométricas de uma segunda fase a uma matriz cerâmica, podendo esses materiais, serem denominados de nanoestruturados (BALDACIM; CAIRO; SILVA, 2001; MANOSSO et al., 2010).

A zircônia, quando utilizada em pequena proporção na forma nanométrica junto à alumina, não apresenta transformação de fase, ou seja, à sua transformação de fase, em fluidos corpóreos. Esse nanocompósitos tem características essenciais para um implante como: elevadas propriedades mecânicas, alta estabilidade química, biocompatibilidade e adequada aparência estética (YONGFENG, et al., 2014; CHINELATTO et al., 2014; SARTORI, 2015).

\subsubsection{Biocerâmicas porosas}

As biocerâmicas porosas, também conhecidas como scaffolds, são materiais com estrutura tridimensional e microporosa. Essas biocerâmicas são capazes de induzir a adesão, o crescimento e diferenciação de células medulares, tal como a formação e crescimento de osso, revascularização osteointegração e remodelação gradual (OLIVIER; FAUCHEUX; HARDOUIN, 2004). São utilizadas para reparar, regenerar e restaurar as funções do tecido ósseo danificado (SHAO et al., 2015). Para isso, as biocerâmicas porosas devem ter poros com tamanho e morfologia de poros (interconectividade e poros arredondados) que afetam diretamente a regeneração óssea em consequência, afetam a adesão celular e o crescimento interno do tecido ósseo. No entanto, poros interligados são mais propensos a formar osso devido a colonização, neovascularização (formação de novos capilares) e o crescimento de células ósseas (migração e adesão dos osteoblastos e osteoclastos) (DENRY; KUHN, 2016; SABREE et al., 2015).

Para a produção de biocerâmicas porosas com formatos complexos, com poros de diferentes diâmetros, interconectados e densidades variadas, deve-se utilizar um processamento adequado e a otimização de propriedades físico-químicas. Quanto mais eficiente o material for nesse aspecto, mais rápido será o crescimento ósseo e sua ligação com o osso recentemente formado (SEPULVEDA; BINNER, 1999).

Em um implante, a influência e aplicação do tamanho e distribuição de poros são de extrema importância para que se possa ter o crescimento ósseo. Trabalhos como de Suchanek e colaboradores (SUCHANEK; YOSHIMURA, 1998), com cerâmicas porosas, mostraram que o 
tamanho mínimo dos poros, necessário para permitir o crescimento interno do osso circundante, juntamente com o fornecimento de sangue, necessidade de migração e transporte, é cerca de $100 \mu \mathrm{m}$. Cranin e colaboradores (CRANIN, A. NORMAN, 1985) evidenciaram que as biocerâmicas porosas devem ter poros de mesmo tamanho (100 $\mu \mathrm{m})$ para fornecer suprimento sanguíneo ao tecido conectivo em crescimento.

Autores como Costa et al. (2008) e Shao et al.(2015) afirmaram que os poros maiores que $100 \mu \mathrm{m}$ podem ocorrer o crescimento ósseo tornando-se facilmente vascularizado.

Em alguns trabalhos (KLAWITTER; HULBERT, 1971a; OH et al., 2007), mostram que para a ocorrência da osteointegração, os poros devem ser maiores que $50 \mu \mathrm{m}$. Poros com dimensões entre 40-100 $\mu \mathrm{m}$ são necessários para crescimento da matriz osteóide e entre 100$350 \mu \mathrm{m}$ para a regeneração óssea. Poros menores de $5 \mu \mathrm{m}$ permitem a neovascularização e entre 5-15 $\mu \mathrm{m}$ o crescimento de fibroblastos.

Os microporos são definidos quando possuem lacunas entre cristais, com dimensões micrométricas (DRLESSEN; KLEIN; GROOT, 1982). De acordo com o trabalho de Cranin, para que um biomaterial seja considerado macroporoso, é necessário que ele apresente poros da ordem 50 a $250 \mu$ m (CRANIN, A. NORMAN, 1985).

Subia e colaboradores, em um de seus trabalhos, resumiram algumas características importantes que um scaffold cerâmico deve ter para que exerça sua função (SUBIA, 2010):

$\checkmark$ Biocompatibilidade, característica importante do material, que é a resposta do tecido no material e efeito do material no tecido hospedeiro;

$\checkmark$ Biofuncionalidade, que é a capacidade que um material implantado possui em atender as características mecânicas necessárias para cumprir a função desejada pelo tempo necessário;

$\checkmark$ Biodegrabilidade, onde o material é degradado ou solubilizado em fluidos tissulares, desaparecendo do local implantado;

$\checkmark$ Velocidade de degradação;

$\checkmark$ Sua superfície não deve atacar quimicamente as células permitindo a proliferação e migração;

$\checkmark$ Poros interconectados com tamanhos adequados (150 - 500 $\mu \mathrm{m}$ ) para ocorrer à infiltração celular e permitir o crescimento continuado do osso no interior do poro;

$\checkmark$ Auxiliar na formação de novos tecidos; 
$\checkmark$ Propriedades mecânicas adequadas para a estrutura a qual foi implantada;

$\checkmark$ Devem imitar a estrutura e função biológica da matriz celular.

Essas características interligadas para melhoria do material, devem ter poros com geometria aproximadamente esférica, paredes densas e microestrutura homogênea. Isso faz com que melhore as propriedades mecânicas destes materiais, pois, os poros com formato esférico, são defeitos críticos presentes e apresentam uma geometria que minimiza a concentração de tensões mecânicas (CAMILO et al., 2009).

\subsection{Técnicas de preparo de Scaffolds cerâmicos}

São várias as técnicas para a fabricação de cerâmicas porosas utilizadas como scaffolds, dentre essas podem ser citadas:

\section{$\checkmark$ Gelcasting}

Essa técnica utiliza pó cerâmico e monômeros orgânicos junto a uma solução aquosa, que polimerizados produzem reticulado de matriz orgânica através de agitação. Ela tornou-se interessante, pois o produto final apresenta alta resistência mecânica, alta porosidade e possibilidade de controle de tamanho e interconectividade de poros com formatos esféricos (SOUSA, 2009; VOLKMER, 2006);

$\checkmark$ Método do material de sacrifício (Sacrificial template)

A formação do material com esse método é através da conformação de corpos a partir de uma mistura contendo uma matriz cerâmica precursora e uma segunda fase sacrificial dispersa homogeneamente. No processo de calcinação, a fase sacrificial (orgânica) é eliminada e os espaços ocupados se transformam em poros com tamanho e forma similares às partículas que os originaram. Como formadores de poros são utilizados uma grande variedade de materiais como amido, polietileno, PMMA (Polimetilmetacrilato), parafina, etc (STUDART et al., 2006);

\section{$\checkmark$ Direct foaming}

É preparada uma barbotina cerâmica onde se introduz ar nessa suspensão a fim de se obter bolhas. Após tratamento térmico, os poros, formados pelas bolhas de ar, são consolidados obtendo alta resistência mecânica. A porosidade total da cerâmica é proporcional à quantidade de ar introduzida na barbotina, porém, o tamanho de poro é 
determinado pela estabilidade da espuma que é controlada de acordo com a quantidade de aditivos (COLOMBO, 2002; STUDART et al., 2006);

\section{$\checkmark$ Impressão 3D}

Método de fabricação, considerado rápido, sendo chamado de LDM (método de fabricação por deposição à baixa temperatura) baseado na técnica layer-by-layer manufacturing (camada por camada). Nesse método, é utilizada uma máquina que deposita materiais formando o scaffolds podendo conter, as células vivas, nutrientes, drogas terapêuticas e materiais cerâmicos. Há um controle de materiais depositados, para que ocorra a formação de órgãos e tecidos sobre o scaffold em 3D (XIONG et al., 2002; YAN et al., 2005).

Também utilizando o método de impressão 3D tem-se o método chamado de sistema de sinterização à laser (SLS). Utiliza um laser de alta potência (como exemplo o de $\mathrm{CO}_{2}$ ) que algumas vezes pode ser até mesmo levado ao ponto de fusão, ocorrendo a formação do corpo da peça camada por camada. Esse laser é guiado por um modelo originalmente projetado, conhecido por CAD (computer aided design - desenho assistido por computador) (FENG et al., 2014);

$\checkmark$ Réplica

Conhecido também como método da esponja polimérica ou método da esponja, baseia-se na impregnação de uma estrutura polimérica celular em uma suspensão cerâmica ou solução precursora a fim de produzir uma cerâmica macroporosa exibindo a mesma morfologia da esponja polimérica original (SCHWARTZWALDER; SOMERS, 1963; STUDART et al., 2006).

Cada método tem sua característica e finalidade, como alta quantidade, tamanho e morfologia de poros, resistência mecânica apropriada para cada aplicação e podem ser aplicados a materiais cerâmicos de diferentes composições químicas (SOUSA, 2009; SOUZA, 2008).

Dentre os métodos apresentados será apresentado com maior detalhe, o método da réplica em razão de ser o método usado na obtenção dos scaffolds neste trabalho.

\subsubsection{Método da Réplica}

O método da réplica é considerado o primeiro método utilizado para obtenção de scaffolds. É também conhecido como método da esponja polimérica devido à utilização de uma esponja como estrutura para a sua fabricação. Esse método é usado para produzir 
cerâmicas porosas que possuem diversas aplicações como por exemplo, filtros resistentes ao calor, catalisador, biocerâmicas porosas, entre outras (SCHWARTZWALDER; SOMERS, 1963).

Por meio deste método, pode-se ter um excelente controle sobre a estrutura, tamanho e formato dos poros. Assim, ele consiste na impregnação de uma esponja polimérica ou natural altamente porosa, em uma barbotina cerâmica, de modo a revestir as paredes da esponja uniformemente. Após a realização da impregnação, retira-se o excesso da suspensão cerâmica (barbotina) e segue-se com um tratamento térmico, onde ocorrerá decomposição do material orgânico e sinterização da fina camada de material cerâmico (STUDART et al., 2006).

Convém ressaltar que é chamado de réplica, pois o corpo cerâmico obtido tem a mesma estrutura da esponja original, com o tamanho e o formato dos poros (SCHWARTZWALDER; SOMERS, 1963; STUDART et al., 2006).

Algumas vantagens desse método como, ser simples de reproduzi-lo, apresentar uma ampla faixa de porosidade, estrutura de célula aberta, alta permeabilidade semelhante a do osso e de baixo custo, quando comparados a outros métodos de processamento, é largamente utilizado na indústria (INNOCENTINI et al., 1998; SCHWARTZWALDER; SOMERS, 1963; STUDART et al., 2006).

Um parâmetro de controle importante para obter corpos cerâmicos com esta técnica é a reologia da barbotina, pois a uniformidade da deposição da camada depende de parâmetros como a viscosidade. O estudo da reologia na suspensão cerâmica é feito por diversos autores com a intensão de diminuir defeitos das cerâmicas porosas, como as trincas e, melhorar a morfologia dos poros, obtendo poros mais arredondados com alisamento dos cantos.

Vários autores perceberam que os principais fatores que influenciam a maior parte da formulação no método da réplica são: o teor de sólidos, a quantidade e o tipo de ligante (GÓMEZ, S. Y. et al., 2012; ZHU et al., 2001). A Figura 3 ilustra a produção de um scaffold obtido pelo método da réplica. 
Figura 3 - Esquema ilustrando o método da Réplica.

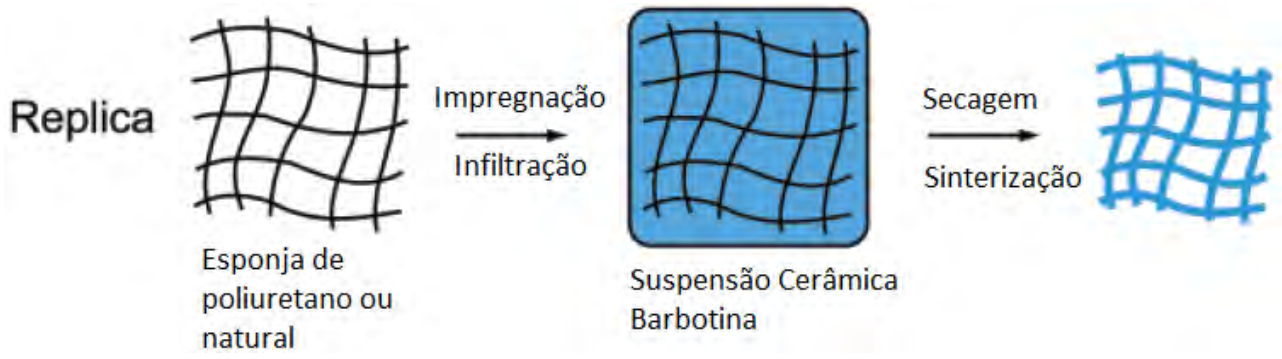

Fonte: (adaptado de (STUDART et al., 2006))

Os scaffolds obtidos por este método podem obter uma porosidade aberta total entre $40 \%$ a $95 \%$ e são caracterizadas por uma estrutura reticulada de poros altamente interligados com tamanhos entre $200 \mu \mathrm{m}$ a $3 \mathrm{~mm}$ (MONTANARO,1998; STUDART et al., 2006).

Uma grande desvantagem desse método são os defeitos encontrados nos filamentos da estrutura reticulada, como os vazios no interior dos filamentos, onde inicialmente era somente a esponja. Outros defeitos são as trincas e também pequenas fissuras provenientes do processo de decomposição do polímero durante a calcinação e sinterização (ZHU et al., 2001).

Fatores como o tamanho da célula da espuma cerâmica altera o comportamento mecânico, que é decorrente do método da réplica (ACCHAR, W. et al., 2009; RAMALHO, 2012). A Figura 4 representa defeitos típicos no processo de fabricação de cerâmica porosa por esse método, devido à volatização do orgânico usado como substrato. Os vazios internos são a principal causa dos baixos níveis de resistência mecânica (ACCHAR, W. et al., 2009; INNOCENTINI et al., 1998; RAMALHO, 2012).

Figura 4 - a) Imagem do scaffold obtido pelo método da réplica. b) Imagem aumentada destacando as microfissuras internas entre os filamentos dos poros em formas de triângulos vazios.

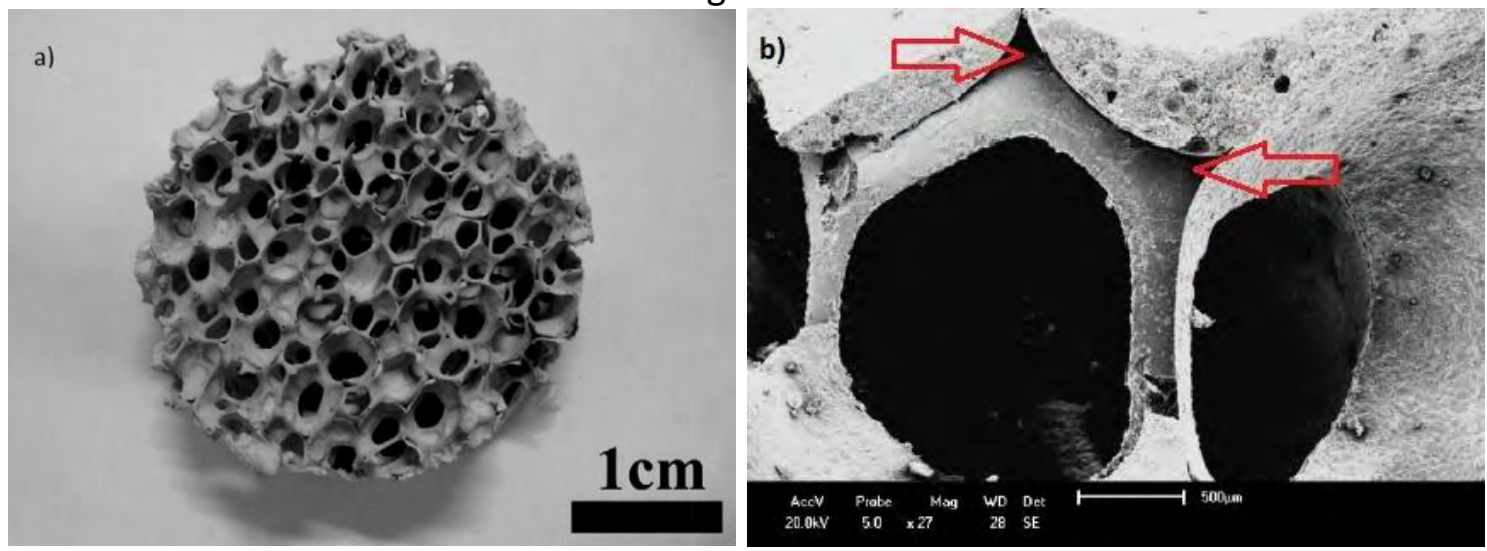

Fonte: (ACCHAR, W. et al., 2009). 
Salvini e Pandolfelli (2002) afirmaram que existem formas de controlar as características das cerâmicas porosas utilizando a réplica, são eles: através da esponja polimérica, sendo o tamanho de poro e porosidade e (número de poros por polegada linear (ppi)). Outra forma importante de controle é pela variação da quantidade de material impregnado. Para esse controle, retira-se o excesso através de calandras, que são constituídas de dois roletes dispostos paralelamente entre si, com abertura entre 20 e $40 \%$ da espessura da esponja (SALVINI; INNOCENTINI; PANDOLFELLI, 2002).

Para o método da réplica são encontradas diversas composições na produção da barbotina. Uma vez que se alteram os elementos da composição, podem-se alterar as características finais das cerâmicas porosas como no trabalho de Zhu e colaboradores (2002). Neste caso, utilizaram na composição para barbotina de $\mathrm{SiC}$ e $\mathrm{Al}_{2} \mathrm{O}_{3}$, como agente estabilizador e espessante, o carboximetil celulose sódica (CMC). O mesmo altera a reologia da solução, como o aumento da viscosidade por meio do aumento da sua porcentagem e, consequentemente, também o acréscimo da densidade, que ocasiona poros mais fechados da cerâmica, alterando as características mecânicas do material (ZHU; JIANG; TAN, 2002). A alteração na reologia da barbotina, em especial a sua viscosidade, é de extrema importância para esse método, devido ao seu preenchimento uniforme e sua interconexão entre os poros.

Ramalho (2012) em seu trabalho utilizou como dispersante $1 \%$ peso de Silicato de Sódio, e 55 \% peso de alumina. A cerâmica porosa produzida apresentou porosidade aparente próxima a 78\% e poros com tamanhos menores que $100 \mu \mathrm{m}$. Mesmo com a obtenção de poros menores, a resistência mecânica submetida à compressão foi baixa, próximo a 1,28 MPa a resistência à compressão, com diminuição na permeabilidade, que se justifica pelas deformidades presentes nos filamentos.

Para os materiais bioinertes, como a $\mathrm{Al}_{2} \mathrm{O}_{3}$ e $\mathrm{ZrO}_{2}$ com um pré tratamento químico superficial, antes do recobrimento, com $\mathrm{H}_{3} \mathrm{PO}_{4}$, com o objetivo de formar na superfície do material grupos hidroxila facilita a deposição dos fosfatos de cálcio (AGUIAR et al., 2008).

\subsection{Tratamento químico superficial em biocerâmicas}

Através de um simples tratamento químico, na superfície do material, pode-se otimizar a formação de grupos funcionais e um aumento na adesão no recobrimento com fosfato de cálcio, sugerindo o aumento do potencial como implante ósseo (JONÁŠOVÁ et al., 2004). 
Neste intuito, há a possibilidade de funcionalização dos scaffolds utilizando tratamento químico na superfície (FAGA, M. G. et al., 2012; RAMBO et al., 2006)

As superfícies das biocerâmicas, tratados quimicamente, antes do recobrimento biomimético, induzem à formação de cargas negativas favorecendo a nucleação da apatita durante a imersão em fluido de SBF (Simulated Body Fluid). Este tipo de tratamento foi estudado por diversos autores (AGUIAR et al., 2008; UCHIDA; KIM; MIYAJI; et al., 2002) usando soluções de ácido fosfórico $\left(\mathrm{H}_{3} \mathrm{PO}_{4}\right)$ e hidróxido de sódio $(\mathrm{NaOH})$, com o intuito de aumentar a área específica de contato e a energia superficial do substrato, ou seja, aumentar a aderência na superfície dos materiais bioinertes, facilitando o crescimento de fases de fosfato de cálcio (SOON et al., 2016).

He e colaboradores (2008) em seu trabalho, também utilizaram o $\mathrm{NaOH}$ no tratamento superficial da cerâmica para melhorar a bioatividade na superfície das cerâmicas bioinertes. Neste trabalho os corpos porosos foram tratadas durante diversos intervalos de tempo $(0,5$, 10, 24 e 48 h) em uma solução de $5 \mathrm{M}$ de $\mathrm{NaOH}$ a $80^{\circ} \mathrm{C}$. Como resultado obtiveram maior adesão e proliferação das células quando a imersão em solução de $\mathrm{NaOH}$ ocorreu nos intervalos de tempo de 5 e $10 \mathrm{~h}$.

No trabalho de Cavalu e colaboradores (2014), foram feitas modificações através de um tratamento na superfície de biocerâmicas de alumina/zircônia com fluoreto de estanho $\left(\mathrm{SnF}_{2}\right)$ e tetrafluoreto de sódio $\left(\mathrm{NaBF}_{4}\right)$, para aplicação em implantes ortopédicos e dentários, os quais mostraram sua eficácia a longo prazo (CAVALU et al., 2014). Isso se deve ao fluoreto que é responsável por controlar o processo de biomineralização dando origem a uma redução no volume do cristal, consequentemente uma estrutura de fosfato de cálcio mais estável (AOBA, 1997; CAVALU et al., 2014; PERDIGAO et al., 2012).

Faga et al. (2012) mostraram que tratamentos químicos superficiais utilizando ácido fosfórico $\left(\mathrm{H}_{3} \mathrm{PO}_{4}\right)$ e hidróxido de sódio $(\mathrm{NaOH})$ a diferentes concentrações, temperaturas e tempo, em compósitos de alumina-zircônia também foram feitos, indicando que, os compósitos tratados superficialmente com ácido fosfórico levaram a formação de grupamentos de fosfato de cálcio após o período de 28 dias de submersão em solução de SBF 1,5 X (FAGA, et al.,2012).

Os trabalhos de Santos (2017) e Sartori (2015), mostraram que, o tratamento químico superficial com solução $\mathrm{H}_{3} \mathrm{PO}_{4}$ com concentração de $5 \mathrm{~mol} / \mathrm{L}$ em cerâmicas de $\mathrm{Al}_{2} \mathrm{O}_{3}$ e 
$\mathrm{Al}_{2} \mathrm{O}_{3} / \mathrm{ZrO}_{2}$ apresentaram, formação uniforme de uma camada de fosfatos de cálcio na sua superfície.

As características físicas e químicas da superfície do material a ser recoberto podem ser determinadas pelas propriedades de um recobrimento. Dessa forma, é de grande importância o estudo sobre a adesão, dependendo do tipo de aplicação a qual um biomaterial se destina (TAVARES, 2002).

\subsection{Métodos de recobrimento usando materiais bioativos}

Os métodos de recobrimento surgiram como uma possibilidade de se combinar a resistência mecânica encontrada nos materiais bioinertes ou biotoléraveis com a bioatividade de outro material depositante (LEGEROS, 1993; VIEIRA, 2013).

Dentre as várias técnicas utilizadas de recobrimentos, aquelas usualmente conhecidas, são: deposição por plasma, ion sputtering, chemical vapor deposition (CVD), imersões em soluções particuladas, eletroforese e sol-gel, que produzem recobrimentos de alta qualidade e filmes com alta densidade. No entanto, estas técnicas possuem algumas desvantagens como o alto custo e baixa resistência à adesão, devido à falta de uma ligação química entre o substrato e o recobrimento de fosfatos de cálcio (LUZ; MANO, 2010).

O método biomimético foi introduzido por Abe e colaboradores (ABE et al., 1990), o qual permite recobrir praticamente boa parte de substratos com uma camada uniforme de fosfatos de cálcio, similar à biológica. O método consiste na imersão do substrato a ser recoberto, em uma solução de SBF que apresenta composição química (concentrações de íons e $\mathrm{pH} 7,4)$, semelhantes ao plasma sanguíneo e temperatura similar à do corpo humano. Essa concentração iônica e pH devem ser similares aos fluidos corpóreos, para geração dos núcleos que proporcionarão o crescimento apropriado de uma camada de fosfato de cálcio.

Na Tabela 4, está representado a composição iônica do plasma sanguíneo e da solução SBF (ABE et al., 1990).

Tabela 4 - Composição iônica do plasma sanguíneo e da solução de SBF (mMol.dm ${ }^{3}$ )

\begin{tabular}{|c|c|c|c|c|c|c|c|c|}
\hline $\mathrm{mMol} \mathrm{dm}^{3}$ & $\mathrm{Na}^{+}$ & $\mathrm{K}^{+}$ & $\mathrm{Mg}^{2+}$ & $\mathrm{Ca}^{2+}$ & $\mathrm{Cl}^{-}$ & $\mathrm{HPO}_{4}{ }^{2-}$ & $\mathrm{SO}_{4}{ }^{2-}$ & $\mathrm{HCO}_{3}{ }^{-}$ \\
\hline Plasma sanguíneo & 142,0 & 5,0 & 1,5 & 2,5 & 103,0 & 1,0 & 0,5 & 27,0 \\
\hline SBF & 142,0 & 5,0 & 1,5 & 2,5 & 147,8 & 1,0 & 0,5 & 4,2 \\
\hline
\end{tabular}

Fonte: ABE, KOKUBO, YAMAMURO, 1990. 
Kokubo e colaboradores em diversos trabalhos (1990; 2004), no desenvolvimento desse método para obtenção de fases de fosfato de cálcio, utilizaram uma placa de vidro bioativo, fornecedora de íons, denominada vidro $\mathrm{G}$ (composição 4,6 $\mathrm{Mg}-44,7 \mathrm{CaO}-34 \mathrm{SiO}_{2}$ $\left.-16,2 \mathrm{P}_{2} \mathrm{O}_{5}-0,5 \mathrm{CaF}_{2} \% \mathrm{wt}\right)$, colocado em conjunto com substrato, sendo que os íons silicato dissolveram-se e foram absorvidos, ocorrendo a nucleação da HA.

Pode-se dizer que um material é capaz de formar fases de fosfato de cálcio em sua superfície na solução de SBF oferecendo vínculo ao osso pela camada formada, desde que o material não contenha substâncias que provoquem reações ao corpo (ABE et al., 1990).

Kim e colaboradores (2004) mostraram que com o aumento do tempo de imersão em solução de $S B F$ a razão de Ca/P aumenta, com o tempo, chegando a 1,83. Após 21 dias, essa razão converge para 1,65. Desde o pH inicial, foi detectado HA, que induziu a formação de apatita óssea em sua superfície através da formação de ACP (Fosfato de cálcio amorfo rico em cálcio). Essa razão é importante, pois demonstra o potencial de bioatividade do SBF e obtém uma fase cerâmica sintética similar o osso natural (KIM et al., 2004).

Barrere e colaboradores (2002), perceberam que ao elevar a concentração da solução de SBF em 5 vezes para recobrir materiais de Ti-6Al- $4 \mathrm{~V}$, a camada de fosfatos de cálcio apresentou maior espessura quando comparada ao recobrimento obtido com solução de SBF padrão, demostrando assim que o tempo de recobrimento pode ser diminuído com o uso de soluções de SBF mais concentradas.

Diversos trabalhos (SIQUEIRA; et al., 2015; ZANIN, HUDSON et al., 2015) mostraram que a utilização da solução de SBF 5x mais concentrada pelo período de incubação de 14 dias, induz a formação de fases de fosfato de cálcio.

Os implantes de HA porosos, biocompatíveis, são comunmente utilizados a forma de preenchimento de pequenos defeitos ósseos (JONES et al., 2007; SHAO et al., 2015).

Uma possibilidade de melhorar a interação osso-implante, é a adição de íons de elementos químicos na estrutura do fosfato de cálcio. Esses íons, quando substituídos, como o $\mathrm{Sr}^{2+}$ apresentam melhor perfomance biológica que seus cristais, podendo produzir desestabilização em sua estrutura o que acarreta sua degradação desacelerada executando funções específicas (IAFISCO et al., 2014). 


\subsection{Incorporação do Estrôncio}

Em cerâmicas à base de fosfato de cálcio existe a possibilidade da substituição de íons na sua rede cristalina. Essa substituição catiônica e aniônica é permitida devido sua alta estabilidade e flexibilidade da estrutura destes compostos causando importantes modificações nas propriedades destes compostos (BOANINI et al., 2010; ELLIOTT, 2013).

Uma vez inseridos esses íons, na rede cristalina dos fosfatos de cálcio, principalmente, nos sítios de íons cálcio, causam importantes modificações nas propriedades destes compostos (ELLIOTT, 2013).

Elementos como $\mathrm{Sr}^{2+}, \mathrm{Mg}^{2+}$ e $\mathrm{Zn}^{2+}$ substituídos na rede promovem a melhoria na estabilidade estrutural e propriedades biológicas dos fosfatos de cálcio, influenciando no metabolismo mineral e no processo de remodelação do tecido ósseo e está relacionada a uma melhoria na proliferação e diferenciação de pré-osteoblastos (GOVINDARAJ et al., 2015). Também é verificado um aumento na síntese de colágeno intra-ósseo e aumento no processo de reabsorção óssea, o que acarreta um restabelecimento mais rápido do tecido ósseo (GOVINDARAJ et al., 2015).

Os elementos do grupo 2 da tabela periódico, o qual o $\mathrm{Sr}^{2+}$ pertence juntamente com $\mathrm{Ca}^{2+}$ e $\mathrm{Mg}^{2+}$, formam cátions divalentes e têm graus variáveis de ligação de proteínas em fluidos biológicos como soro ou plasma. A ligação protéica de $\mathrm{Sr}^{2+}$ no soro ou plasma está na mesma ordem de magnitude que a de $\mathrm{Ca}$. Na Tabela 5 são apresentadas algumas diferenças importantes entre $\mathrm{Mg}^{2+}, \mathrm{Ca}^{2+}$ e $\mathrm{Sr}^{2+}$ encontrados no corpo humano, podendo-se destacar a presença do $\mathrm{Sr}^{2+}$ (COMAR et al.1960; NIELSEN, 2004).

Tabela 5 - Propriedades físicas dos elementos do grupo 2 da tabela periódica, biologicamente importantes e sua distribuição no corpo de um homem padrão de $70 \mathrm{~kg}$.

\begin{tabular}{lllll}
\hline Elemento & $\begin{array}{c}\text { Número } \\
\text { atômico }\end{array}$ & $\begin{array}{c}\text { Peso } \\
\text { atômico }\end{array}$ & $\begin{array}{c}\text { Massa } \\
(\mathbf{g})\end{array}$ & $\begin{array}{c}\text { \% de massa } \\
\text { no corpo }\end{array}$ \\
\hline $\mathbf{M g}^{2+}$ & 12 & 24,32 & 19 & 0,027 \\
$\mathbf{C a}^{2+}$ & 20 & 40,08 & 1000 & 1,4 \\
$\mathrm{Sr}^{2+}$ & 38 & 87,63 & 0,32 & 0,00044 \\
\hline
\end{tabular}

Fonte: (NIELSEN, 2004)

Eles têm sido usados como excelentes ferramentas para estudos cinéticos, substituindo cálcio, pois, tem comportamento parecidos no corpo humano, ambos com fortes propriedades ligadas aos ossos. No entanto, existem diferenças biológicas entre os dois 
elementos, explicável em parte pelo tamanho maior da molécula de estrôncio (NIELSEN, 2004).

A substituição do $\mathrm{Ca}^{2+}$ pelo $\mathrm{Sr}^{2+}$ deve-se a posição deles na tabela periódica, ou seja, elementos do grupo 2 o qual formam íons (cátion) divalentes em fluidos biológicos como o plasma sanguíneo, sendo a proteína de ligação do estrôncio, no plasma sanguíneo, da mesma ordem de grandeza do cálcio, porém, as diferenças biológicas entre os dois elementos existem, explicáveis em parte, pelo raio atômico como da molécula de estrôncio (COMAR et al.1960; NIELSEN, 2004). Um outro fato que mostra a diposição em ocorrer a substituição iônica na rede HA é a alta flexibilidade de sua estrutura ocorrendo especificamente nos sítios ocupados normalmente por $\mathrm{Ca}^{2+}$, substituídos por cátions bivalentes (como exemplo, $\mathrm{Sr}^{2+}$, $\mathrm{Ba}^{2+}, \mathrm{Mg}^{2+}$, etc) e monovalentes. Na Figura 5, ilustra cátions substitutos e substituídos na rede cristalina da HA (ANTONIAC, 2016).

Figura 5 - Desenho esquemático da dissolução parcial/precipitação de apatitas biológicas in vivo e substituições iónicas no cristal de HA (LIU, Q. et al., 2013).

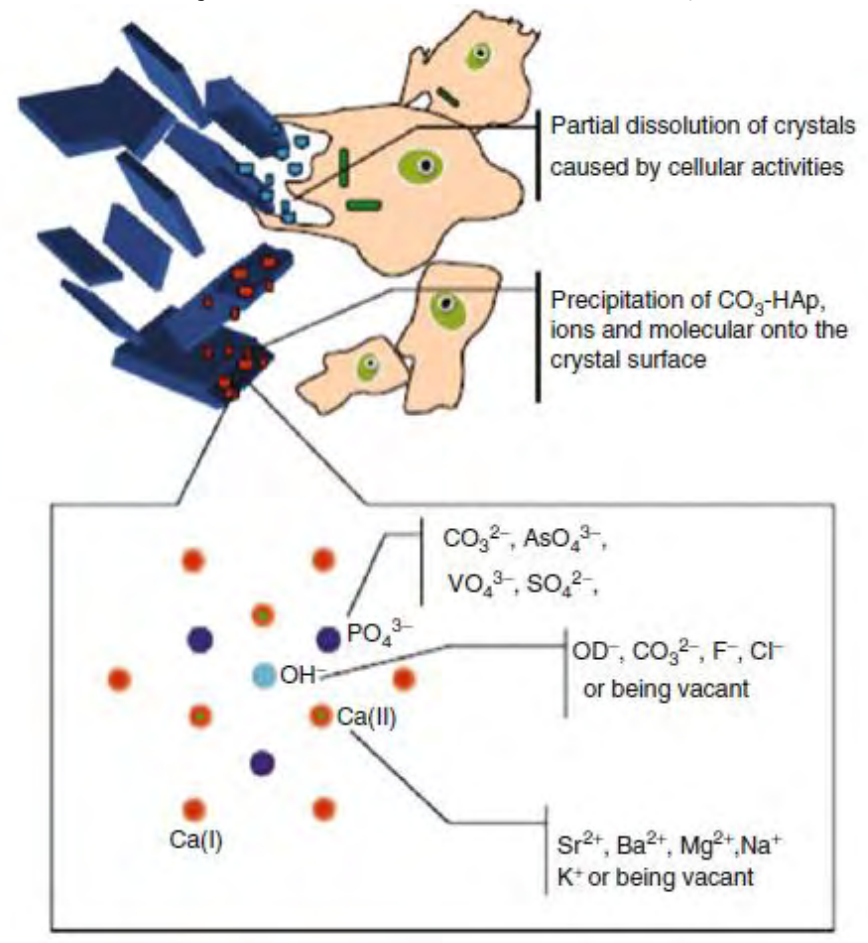

As vacâncias dos íons $\mathrm{Ca}^{2+}$ são substituídas, causando uma alteração da rede, em termos de contração ou expansão dos parâmetros da rede, com base no diâmetro do íon. Mesmo que se preveja que cátions maiores modifiquem o volume celular, levando a uma expansão acompanhada de valores maiores de parâmetro de eixo, isto nem sempre ocorre, 
como no caso da substituição de cátions monovalentes por cátions bivalentes (ANTONIAC, 2016).

Estudos mostraram que as estruturas porosas levam à incorporação de fosfato de cálcio e aumentam a adsorção de proteínas, quando ocorre a substituição do estrôncio, melhorando a resposta celular (LIM et al., 2009).

Um outro fato da substituição do $\mathrm{Ca}^{2+}$ pelo $\mathrm{Sr}^{2+}$ é mostrado pela disposição em ocorrer a substituição iônica na rede HA é a alta flexibilidade de sua estrutura ocorrendo especificamente nos sítios ocupados normalmente por $\mathrm{Ca}^{2+}$, substituídos por cátions bivalentes (como exemplo, $\mathrm{Sr}^{2+}, \mathrm{Ba}^{2+}, \mathrm{Mg}^{2+}$, etc) e monovalentes (ANTONIAC, 2016).

De fato, no caso de substituições com íons bivalentes $\left(\mathrm{Mg}^{2+}, \mathrm{Zn}^{2+}, \mathrm{Sr}^{2+}\right)$, não ocorre desequilíbrio de carga dentro da malha de fosfato de cálcio, enquanto que no caso de substituições com íons monovalentes $\left(\mathrm{Na}^{+}\right.$e $\left.\mathrm{K}^{+}\right)$, ocorre um desequilíbrio de cargas, pois, é necessário respeitar a neutralidade. É evidente que, a neutralidade é mantida, ou a formação de sítios suplementares na ocorrência de substituições simultâneas de cátions e ânions (ANTONIAC, 2016).

Essa substituição iônica pelo estrôncio nas biocerâmicas que contenham fosfato de cálcio, melhora as características como osteointegração e bioatividade, podendo acontecer naturalmente nos ossos e nos dentes impactando diretamente no crescimento ósseo, osteocondutividade e aumento da força de ligação ao osso e quando utilizado no tratamento de osteoporose como efeito, promove aumento da formação óssea e reduz sua reabsorção, estimulando a atividade dos osteoblastos e osteoclastos (GOVINDARAJ et al., 2015; IAFISCO et al., 2014; MARIE et al., 2001; REGINSTER et al., 2009). Esses favorecimentos biológicos indicam que a substituição pelo $\mathrm{Sr}^{2+}$ pode atuar como um elemento de substituição de duplo efeito, associado à redução da reabsorção óssea e ao aumento da formação óssea (GOVINDARAJ et al., 2015; LI, YUNFENG et al., 2010; QUERIDO et al., 2014).

O estrôncio, usado na substituição iônica, tem aumento nas características como: biocompatibilidade, osteocondutividade e aumento da força de ligação ao osso e quando utilizado no tratamento de osteoporose como efeito, promove aumento da formação óssea e reduz sua reabsorção, estimulando a atividade dos osteoblastos e osteoclastos (GOVINDARAJ et al., 2015; IAFISCO et al., 2014; MARIE et al., 2001; REGINSTER et al., 2009). 
Com a adição de elemento como $\mathrm{Sr}^{2+}$ junto ao recobrimento, ocorre a substituição do $\mathrm{Ca}^{2+}$ pelo $\mathrm{Sr}^{2+}$ acarretando um aumento na bioatividade dos materiais. Isso pode ser verificado através da diminuição na razão $C a / P$, que não é afetada, pois, existe semelhança física e química entre os elementos $\mathrm{Ca}^{2+}$ e $\mathrm{Sr}^{2+}$.

Como no trabalho de IAFISCO e colaboradores (2014) a incorporação de estrôncio no fosfato de cálcio é capaz de entrar na estrutura demonstrando seu potencial para aplicação como material para tratamento da osteoporose, que comumente ocorre nas mulheres com deficiência de estrogênio após a menopausa e eficaz para o alívio das dores ósseas e para o tratamento de câncer ósseo (DAHL et al., 2001; MAEDA; LAZARETTI-CASTRO, 2014).

Quando ocorre o aumento da concentração de íons de $\mathrm{Sr}^{2+}$ em solução ocorre uma diminuição do tamanho, cristalinidades das partículas, a carga superficial, a solubilidade e outras propriedades fundamentais, levando a importantes mudanças em seu desempenho biológico, estabilidade térmica, solubilidade, resposta osteoclástica e osteoblástica (Hanifi et al, ANTONIAC, 2016; 2010).

$\mathrm{O} \mathrm{Sr}^{2+}$ na estrutura de fosfato de cálcio, promove dissolução lenta do estrôncio, isso mostra um comportamento propício para o desempenho farmacológico. A liberação dos íons causa um aumento da concentração de cálcio e fósforo, facilitando o processo de mineralização que, acarreta a formação e crescimento ósseo (GOVINDARAJ et al., 2015; NIELSEN, 2004). Esse aumento é devido a superfície dos osteóides e dos osteoblastos sugerindo o aumento da superfície formadora de ossos (GRYNPAS et al., 1996). A mineralização distingue entre os componentes mineral e orgânico da matriz sólido, e é a fração em massa do mineral (MARTIN, 1991). Por outro lado, a mineralização também pode ser afetada pela calcificação defeituosa de osteóide ou de cartilagem de crescimento em crianças (raquitismo) (MARTIN, 1991).

Em um período curto de tempo, quando o $\mathrm{Sr}^{2+}$ está ligado ao osso, transfere-se à superfície da fase mineralizada realizando trocas iônicas com os cristais de fosfato de cálcio por adsorção à superfície ou no interior da rede cristalina substituindo de íons Ca (LI, YUNFENG et al., 2010; REGINSTER et al., 2005)

Através dos trabalhos estudados, será mostrado que os scaffolds de alumina e alumina-zircônia tratados superficialmente com $\mathrm{H}_{3} \mathrm{PO}_{4}$ e recobertos pelo método biomimético $5 x$ (cinco vezes mais concentrado) e com tratamento utilizando íons de $\mathrm{Sr}^{2+}$ apresenta boas 
propriedades de biocompatibilidade, potencial elemento no aumento da solubilidade (reabsorção) óssea e ligação na camada de fosfato de cálcio. 


\section{PROCEDIMENTO EXPERIMENTAL}

Neste capítulo são descritos os materiais e métodos que foram utilizados para produção deste trabalho. A Figura 6 apresenta, resumidamente, um fluxograma das etapas realizadas no processo de produção e caracterização dos corpos porosos.

Figura 6 - Fluxograma representando resumidamente as etapas realizadas no processo de produção e caracterização dos corpos porosos recobertas com fosfato de cálcio.

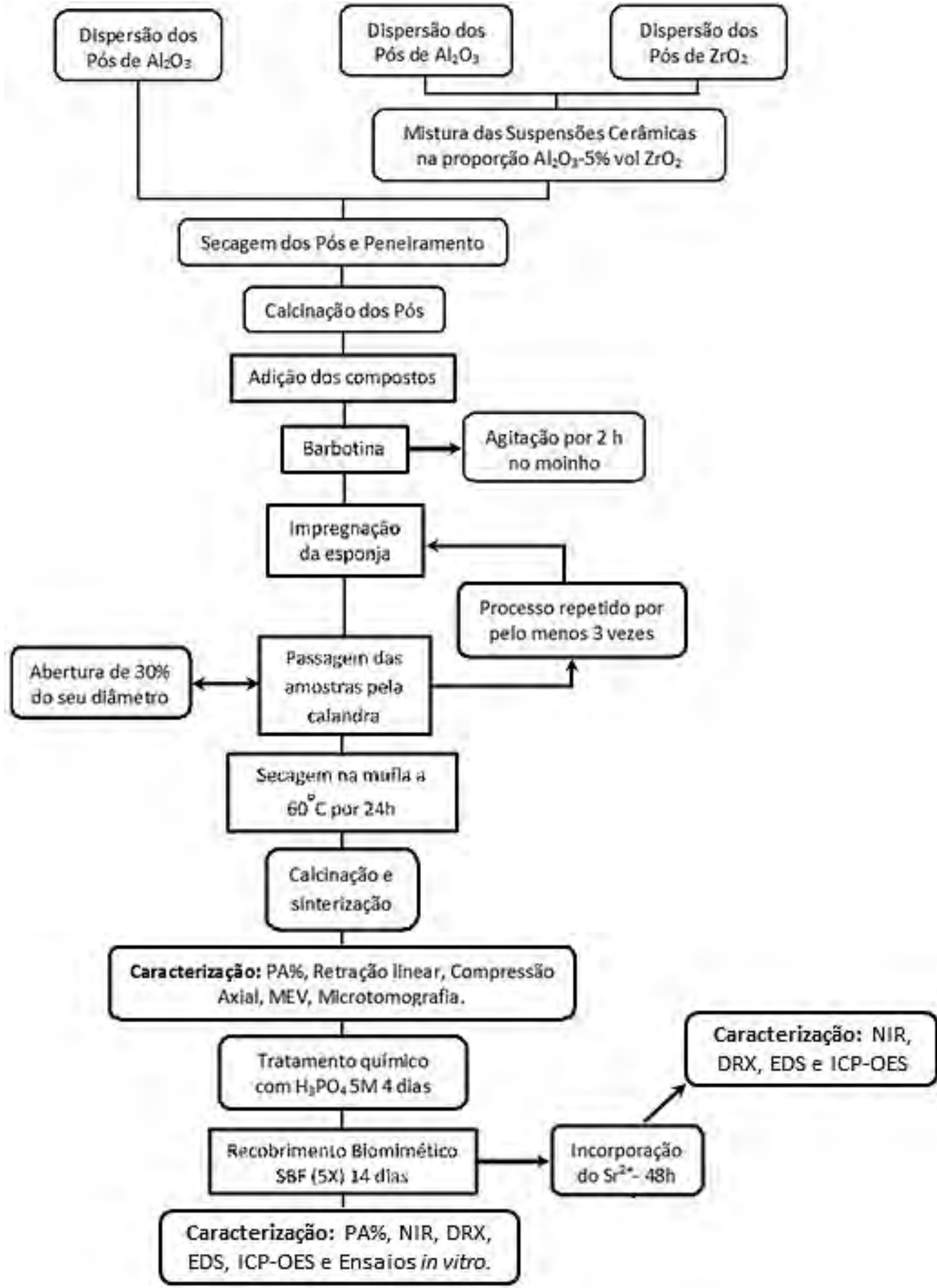


Para produção dos corpos de prova porosos de alumina e alumina-zircônia, utilizou-se alumina AKP-53 produzida pela Sumitomo Chemical, Japão, com tamanho médio de partículas em torno de 0,25 $\mu \mathrm{m}$, área superficial específica de 13,6 $\mathrm{m}^{2} / \mathrm{g}$ e pureza de $99,995 \%$, dados fornecidos pelo fabricante. O pó de zircônia na forma nanométrica parcialmente estabilizada (3\% mol ytria), produzida pela Nanostructured \& Amorphous Materials Inc. (MA-USA), com tamanho médio de partículas em torno de $30-65 \mathrm{~nm}$, área superficial 19,8 $\mathrm{m}^{2} / \mathrm{g}$ e pureza de $99,9 \%$.

Como aditivos, para a preparação dos pós e das barbotinas de alumina e alumina com 5\% em volume de zircônia, foram utilizados os reagentes apresentados na Tabela 6 .

Tabela 6 - Reagentes utilizados na produção dos corpos de prova porosos.

\begin{tabular}{l|l}
\hline \multicolumn{1}{c|}{ Reagentes } & \multicolumn{1}{c}{ Fabricante } \\
\hline Álcool Polivinílico (PVA) & Vetec quimica fina \\
\hline Ácido Oléico & Vetec quimica fina \\
\hline Poliacrilatos de amônia & Disperlan LA (Lambra) \\
\hline Polietileno glicol & Vetec quimica fina \\
Carboximetilcelulose (CMC sódica) & Sigma-Aldrich \\
\hline Glicerina Bi-destilada & Synth \\
\hline Ácido 4-aminobenzóico- PABA & Vetec - Química Fina \\
Cloreto de Magnésio Hexahidratado & Labsynth - Produtos para laboratório \\
na forma de solução - $\mathbf{M g C l}_{\mathbf{2}} \mathbf{6} \mathbf{H}_{\mathbf{2}} \mathbf{O}$ & LTDA \\
Álcool etílico ABS.ACS, $\mathbf{9 9 , 5 \%}$ de & ECIBRA- Reagentes Analíticos (Indústria \\
pureza & e Comércio de Produtos Químicos LTDA) \\
\hline
\end{tabular}

\subsection{Preparação dos pós}

A preparação dos corpos porosos de alumina e alumina contendo $5 \%$ de inclusões nanométricas de zircônia, foram realizadas baseado em estudos anteriores desenvolvido pelo grupo (CHINELATTO et al., 2014; GUIMARAES et al., 2009; SARTORI, 2015).

\subsubsection{Preparação dos pós de Alumina}

Uma suspensão de $\mathrm{Al}_{2} \mathrm{O}_{3}$ foi preparada em um moinho de bolas convencional usando a relação bola/material 5:1, em um frasco de polipropileno com 0,2\% em peso de PABA (ácido 4-aminobenzóico) e 0,5 \% em peso de ácido oleico em meio alcoólico, por 1 hora. 
Com o intuito de melhorar a sinterabilidade e minimizar o crescimento de grãos, foi adicionado durante, para os pós de alumina e alumina zircônia, a moagem 100 ppm de óxido de magnésio na forma de cloreto de magnésio hexahidratado $\left(\mathrm{MgCl}_{2} \cdot 6 \mathrm{H}_{2} \mathrm{O}\right)$.

Após a moagem dos pós, a secagem foi realizada utilizando fluxo de ar quente. Em seguida, o pó foi passado em peneira de malha 80 mesh e calcinados a $600{ }^{\circ} \mathrm{C} / 2 \mathrm{~h}$, usando taxa de aquecimento de $1^{\circ} \mathrm{C} / \mathrm{min}$, para eliminação dos materiais orgânicos adicionados.

\subsubsection{Preparação dos pós de Alumina/Zircônia}

Para a preparação dos pós de alumina contendo $5 \%$ vol de inclusões de zircônia , foi utilizado o mesmo procedimento desenvolvido em estudos realizados anteriormente pelo grupo de trabalho (CHINELATTO et al., 2014; GUIMARAES et al., 2009; TROMBINI et al., 2007). Três etapas caracterizaram esse procedimento de mistura.

a) Preparação da suspensão de alumina: a alumina foi preparada em um moinho de bolas usando a relação bola:material de 5:1, em um frasco de polipropileno com $0,2 \%$ em peso de PABA em meio alcoólico por 1 hora.

b) Preparação da suspensão de zircônia: a zircônia nanométrica foi desaglomerada em um moinho de bolas usando a relação bola:material de 4:1, em um frasco de polipropileno com $0,5 \%$ em peso de PABA em meio alcoólico por 12 horas.

c) Mistura das suspensões de alumina e zircônia: foi adicionada $5 \%$ em volume da suspensão de zircônia à suspensão de alumina. O frasco com a mistura das suspensões foi levado ao moinho de bolas por 22 horas sob agitação contínua. Na sequência foi adicionado 0,5 \% em peso de ácido oleico e 100 ppm de óxido de magnésio na forma de cloreto de magnésio hexahidratado $\left(\mathrm{MgCl}_{2} \cdot 6 \mathrm{H}_{2} \mathrm{O}\right)$, seguindo a mistura por mais 2 horas.

Após mistura, foi realizada a secagem dos pós utilizando fluxo de ar quente, em seguida passados em peneira de malha 80 mesh e calcinados a $600^{\circ} \mathrm{C} / 2 \mathrm{~h}$, usando taxa de aquecimento de $1^{\circ} \mathrm{C} / \mathrm{min}$, para eliminação dos materiais orgânicos.

\subsection{Preparação da barbotina para produção os corpos porosos}

Durante todo o processo, desde a escolha dos compostos utilizados para a preparação da barbotina até o tratamento térmico dos corpos porosos, foram feitos diversos testes visando uma melhor impregnação da esponja polimérica, para se obter paredes dos corpos 
porosos uniformes sem trincas, com poros interconectados e maior preenchimento de todos os poros na esponja. Foram feitos alguns estudos de trabalhos já desenvolvidos com o intuito de encontrar uma melhor composição (ACCHAR, W. et al., 2009).

Com o objetivo de avaliar os diversos fatores que podem ter alguma influência nas propriedades da suspensão de alumina, foi realizado um planejamento de estudo no qual foram variadas as porcentagens de sólidos na suspensão, a concentração do ligante e também do dispersante.

No Anexo 1, estão descritas as composições testadas visando encontrar a melhor condição usada no desenvolvimento deste trabalho.

Na Tabela 7 são descritos os compostos e percentagens utilizadas para a produção dos corpos porosos cerâmicos de alumina e alumina-zircônia.

\begin{tabular}{|c|c|c|}
\hline \multicolumn{2}{|c|}{$\begin{array}{l}\text { Compostos } \\
\text { utilizados }\end{array}$} & $\begin{array}{l}\text { Percentagem utilizada } \\
\text { de cada composto (\%wt) }\end{array}$ \\
\hline Alumina & $\begin{array}{l}\text { Alumina- } \\
\text { Zircônia }\end{array}$ & 55,00 \\
\hline \multicolumn{2}{|c|}{ Disperlan } & 1,43 \\
\hline \multicolumn{2}{|l|}{ Glicerina } & 3,03 \\
\hline \multicolumn{2}{|c|}{ Polietileno glicol } & 0,70 \\
\hline \multicolumn{2}{|c|}{ Ácido oleico } & 0,30 \\
\hline \multicolumn{2}{|c|}{ Solução CMC } & 0,83 \\
\hline \multicolumn{2}{|c|}{ Solução PVA } & 14,00 \\
\hline \multicolumn{2}{|c|}{ Água deionizada } & 24,72 \\
\hline
\end{tabular}

A suspensão da barbotina de alumina e alumina-zircônia foi preparada em um frasco de polipropileno contendo esferas de zircônia de 5,5 mm de diâmetro, em moinho de bolas, utilizando água destilada e o agente defloculante (DISPERLAN), por um período de 24 horas utilizando relação bola:material de 4:1. Após esse período, foram adicionados à solução os compostos: glicerina (função de plastificante), polietileno glicol (função de ligante), ácido oleico (lubrificante), solução de CMC (função de agente espessante e agente adesivo) e solução de PVA (função de ligante), e o frasco retornou no moinho de bolas por mais duas horas. 


\subsubsection{Preparação dos corpos porosos}

Para a preparação dos corpos de prova, foi utilizada uma esponja comercial, como destacada na Figura 7 (a) e (b) imagens obtidas por microscopia eletrônica de varredura (MEV) da esponja utilizada. Para a produção desses corpos porosos, foram cortadas esponjas na forma cilíndrica com dimensão de $2 \mathrm{~cm}$ de altura por $1 \mathrm{~cm}$ de diâmetro e 0,3 cm de altura, para impregnação, para posterior caracterização física e recobrimento biomimético. Para isso as esponjas foram imersas na barbotina e, em seguida, inseridas em uma calandra com abertura de $30 \%$ do tamanho de cada corpo poroso. Esse procedimento foi repetido por pelo menos 3 vezes. Após a impregnação, os corpos de prova foram colocados em estufa a $60^{\circ} \mathrm{C} / 24$ h.

Figura 7 - (a) e (b) - Imagens obtidas por MEV da esponja utilizada para impregnação na barbotina.

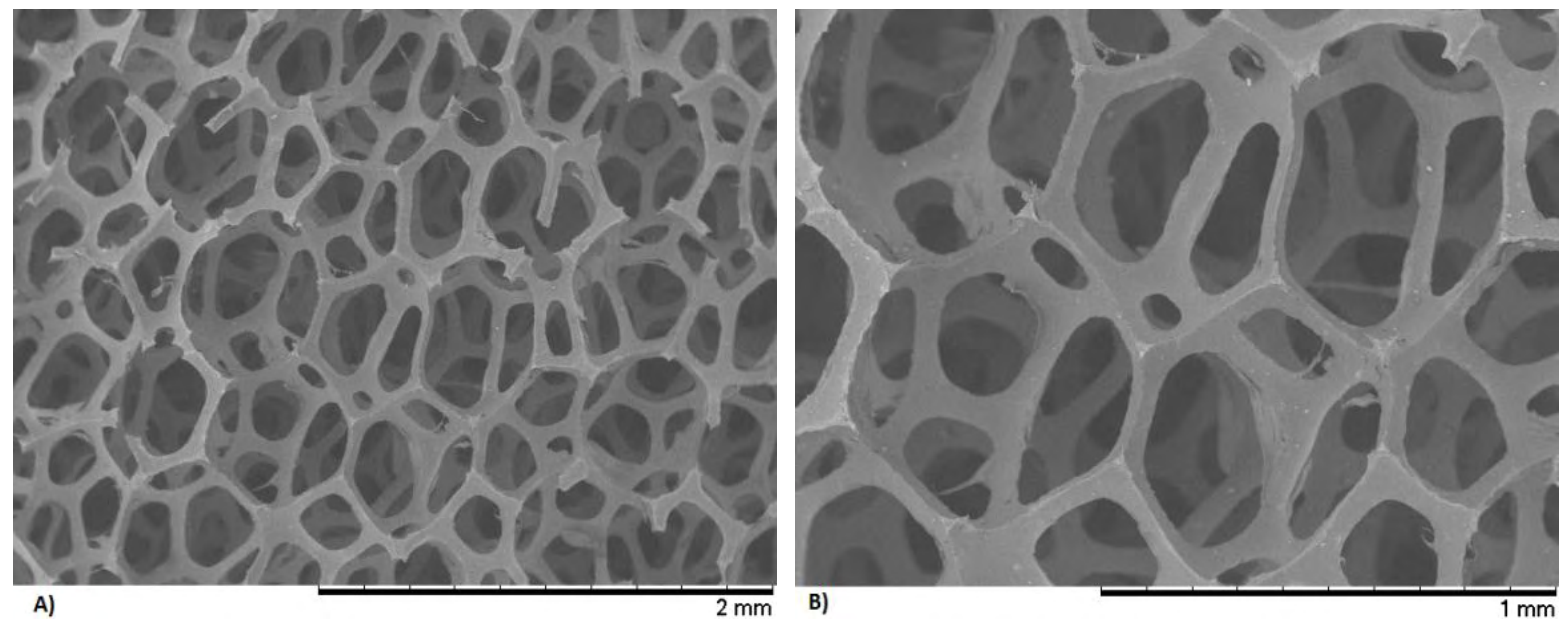

\subsection{Calcinação e sinterização dos corpos porosos de alumina e alumina/zircônia}

A etapa de tratamento térmico pode ser considerada como uma das mais importantes do método da réplica devido a decomposição da esponja e consolidação da estrutura cerâmica.

Para a calcinados dos corpos impregnados e secos em estufa utilizou-se uma mufla de marca Marcon - MA 385, usando taxa de aquecimento de $0,5^{\circ} \mathrm{C} / \mathrm{min}$, até a temperatura de $600{ }^{\circ} \mathrm{C}$ e patamar de $1 \mathrm{~h}$. Essa etapa visa à decomposição da esponja polimérica e outros aditivos orgânicos provenientes do seu processamento.

A sinterização foi realizada em forno da marca MAITEC -1700, usando taxa de aquecimento de $10^{\circ} \mathrm{C} / \mathrm{min}$, até $1500^{\circ} \mathrm{C}$ e patamar de $2 \mathrm{~h}$. A Figura 8 apresenta as curvas de tempo X temperatura usadas na calcinação e sinterização. 
Figura 8 - Gráfico representando as taxas de aquecimento $X$ temperatura utilizadas no processo de calcinação e sinterização.

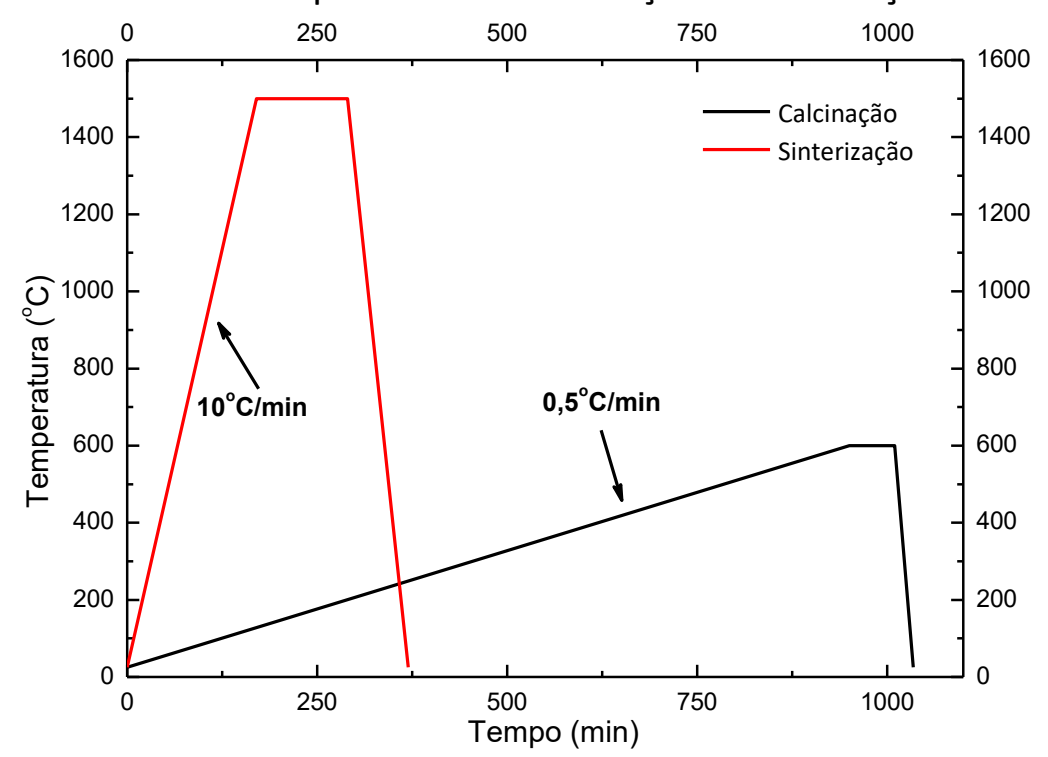

\subsection{Caracterização dos corpos porosos}

Os corpos de prova foram caracterizados por medidas de retração linear, densidade e porosidade aparente, microscopia eletrônica de varredura, microtomografia e compressão axial. Para simplificar a identificação utilizou-se A para alumina e AZ para alumina-zircônia

\subsubsection{Densidade aparente e Porosidade aparente}

Os parâmetros de densidade aparente e porosidade aparente foram determinados pelo método de imersão baseado no Princípio de Arquimedes (ASTM, 1999), utilizando uma balança da marca analítica Tecnal modelo B-tec 210 A, com aparato para medida dos corpos imersos.

Como líquido para imersão dos corpos porosos, foi utilizado água destilada à temperatura ambiente.

As Equações 1 e 2 descrevem, respectivamente, os cálculos que foram usados nas medidas de densidade aparente e porosidade aparente.

$\mathrm{DA}=\left(\frac{M_{\text {seca }}}{M_{\text {úmida }}-M_{\text {imersa }}}\right) \cdot \rho_{a}$

Equação 1

Onde:

DA: Densidade Aparente;

$M_{\text {seca: }}$ : Massa da amostra seca; 
Múmida: Massa da amostra úmida após ter permanecida imersa em água durante 24 horas;

Mimersa: Massa da amostra imersa em água;

$\rho_{a}$ : densidade da água $\left(\mathrm{g} / \mathrm{cm}^{3}\right)$;

$\mathrm{PA}=\left(\frac{M_{\text {úmida }}-M_{\text {seca }}}{M_{\text {úmida }}-M_{\text {imersa }}}\right) \cdot 100$

Equação 2

Onde: PA: Porosidade aparente.

O objetivo destas caracterizações físicas e microestruturais foi verificado o tamanho, formato e interconectividade dos poros.

\subsubsection{Retração Linear}

A retração linear foi medida utilizando a Equação 3 (ASTM, 2014a).

$\mathbf{R L}=\left[\frac{\mathbf{L}_{\mathbf{i}}-\mathbf{L}_{\mathbf{f}}}{\mathbf{L}_{\mathrm{f}}}\right] .100$

Equação 3

Onde:

$\mathrm{RL}$ : Retração linear (\%)

$L_{i}$ : Comprimento do corpo de prova antes da sinterização

$L_{f}$ : Comprimento do corpo de prova após a sinterização

\subsubsection{Microscopia Eletrônica de Varredura}

A caracterização microestrutural após a sinterização foi realizada utilizando um microscópio eletrônico de varredura (MEV), modelo TM-3000, Hitachi Japão. O objetivo da análise foi caracterizar a interconectividade e uniformidade nas paredes da cerâmica, que são consequências do processo de impregnação. As análises foram realizadas na superfície de fratura e na superfície polida dos corpos de prova. Para a caracterização da superfície polida dos corpos porosos utilizou-se um MEV FEG - XL 30 - Philips. Para o preparo da superfície polida, os corpos de prova foram embutidos em resina de poliéster em câmara de vácuo e polidos em politriz automática minimet da Buehler, utilizando pasta de diamante nas granulometrias de $9 \mu \mathrm{m}, 6 \mu \mathrm{m}, 3 \mu \mathrm{m}$ e $1 \mu \mathrm{m}$.

Para a observação no MEV, os corpos de prova polidos e atacados termicamente foram recobertos com uma fina camada de ouro, depositada por meio de uma evaporadora Balzers, 
modelo SCD-004, e observados em um microscópio de alta resolução Philips, modelo XL-30 FEG.

\subsubsection{Microtomografia Computadorizada de Raios $X$}

Através de um método não destrutivo, a microtomografia computadorizada de raios $\mathrm{X}$ $(\mu \mathrm{CT})$ gera imagens tridimensionais para caracterização de estruturas. A visualização tridimensional auxilia no entendimento da morfologia dos corpos analisados podendo ter uma visão espacial de como as conexões internas estão dispostas e interligadas (LIMA, I. et al., 2007). Além de informações da porosidade, pode-se avaliar a distribuição interna do tamanho de poros.

As análises de tamanho e distribuição do tamanho de poros foram realizadas a partir das imagens de $\mu \mathrm{CT}$, em um Microtomógrafo de Raios-X Sky Scan 1172. As imagens e os dados experimentais obtidos foram tratados e analisados pelo software CT-Analyser.

\subsubsection{Ensaios de compressão axial}

Os corpos porosos, preparados na forma cilíndrica, foram ensaiados por compressão axial usando pastilhas de aço fixadas a sua superfície através de adesivo epóxi, visando promover apoio das superfícies planas.

A Figura 9 apresenta o esquema utilizado na realização dos ensaios de compressão axial, adaptado de alguns trabalhos (CAMILO et al., 2009; COSTA et al., 2008; KWON et al., 2002).

Figura 9 - Representação esquemática das pastilhas de aço fixadas no corpo de prova cilíndrico para os ensaios de compressão.

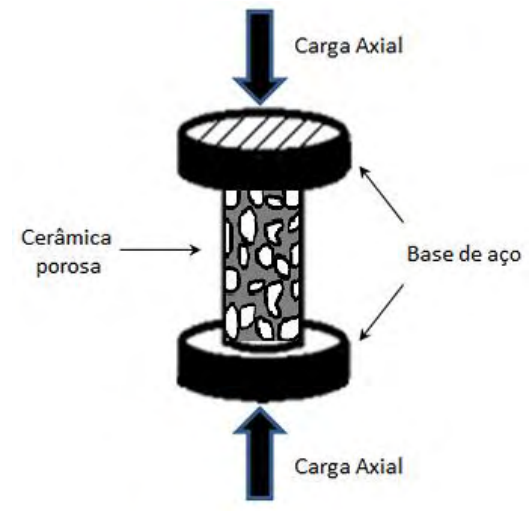

Os ensaios foram realizados em uma máquina universal de ensaios servo-hidráulica, modelo 370.02, fabricante MTS Landmark. Foram utilizados taxa de compressão de 1,5 
$\mathrm{mm} / \mathrm{min}$, célula de carga de capacidade máxima de $1 \mathrm{kN}$ com carga inicial de $5 \mathrm{~N}$ e acessório para ensaio de compressão axial, com rótula para garantir a distribuição uniforme de carga nas superfícies dos corpos de prova não simétricos.

Foram ensaiados cinco corpos de prova de cada composição.

\subsection{Tratamento químico superficial dos corpos porosos}

Após as caracterizações dos corpos porosos de alumina e alumina-zircônia, os mesmos receberam tratamento químico superficial com solução de ácido fosfórico $\left(\mathrm{H}_{3} \mathrm{PO}_{4}\right)$, visando melhorar a aderência, uniformidade e bioatividade da camada de fosfato de cálcio a ser depositada. Utilizou-se os mesmos procedimentos realizados pelo grupo de pesquisa, o qual esse trabalho foi desenvolvido (SANTOS et al.,2015; SARTORI, 2015).

Para a realização do tratamento químico superficial, os corpos porosos foram imersas em solução de $\mathrm{H}_{3} \mathrm{PO}_{4} 5 \mathrm{M}$, a temperatura de $90{ }^{\circ} \mathrm{C}$ durante 4 dias, em banho termostático, acoplado a um sistema de refluxo, o que descartou a necessidade de reposição da solução (AGUIAR et al., 2008; FAGA, M. et al., 2012; HE et al., 2008).

A determinação do volume adequado de solução para o tratamento químico foi determinado pela relação apresentada na Equação 4 (ISO FDIS 23.317, 2005).

$$
V_{s}=\frac{s_{a}}{10}
$$

\section{Equação 4}

Onde:

$V_{s}$ : volume da solução $\left(\mathrm{m}^{3}\right)$;

$S_{a}:$ área superficial da amostra $\left(\mathrm{m}^{2}\right)$;

Após o tempo de tratamento, os corpos porosos foram lavados com água deionizada e secas em estufa à temperatura de $60^{\circ} \mathrm{C}$ por 24 horas.

\subsection{Recobrimento biomimético}

Após tratamento químico superficial os corpos porosos foram recobertos com fosfatos de cálcio utilizando o método biomimético.

Para isso a solução de SBF $5 x$ foi preparada na forma da solução clássica já produzida por diversos autores (ABE et al., 1990; KOKUBO, TADASHI et al., 1990), porém com concentrações de íons 5 vezes maior (BARRERE et al., 2002). Alternativas, tais como o aumento da concentração do meio de $S B F$, apresentam-se como candidato a deposição de 
camadas de fosfatos de cálcio em curtos períodos de tempo e de forma homogênea (GROSS; MÜLLER-MAI; VOIGT, 1990).

A Tabela 8 mostra os componentes e quantidades utilizadas para preparação da solução de $S B F 5 x$.

Tabela 8 - Representação dos componentes e quantidades utilizadas para a produção do SBF (5x) (BARRERE et al, 2002; LOBO, A. O., 2011).

\begin{tabular}{c|c|c|c|c|c}
\hline Componente & $\mathbf{N a C l}$ & $\mathbf{M g C l}_{\mathbf{2} .6 \mathrm{H}_{2} \mathbf{O}}$ & $\mathrm{CaCl}_{\mathbf{2}} \mathbf{. 2} \mathrm{H}_{\mathbf{2}} \mathrm{O}$ & $\mathbf{N a}_{2} \mathrm{HPO}_{\mathbf{4}} . \mathbf{2} \mathrm{H}_{\mathbf{2}} \mathbf{O}$ & $\mathbf{N a H C O}_{\mathbf{3}}$ \\
\hline Quantidade (g/L) & 40 & 1,52 & 1,84 & 0,89 & 1,76 \\
\hline
\end{tabular}

Para a preparação do SBF $5 \mathrm{x}$, os componentes foram dissolvidos em meio aquoso à temperatura ambiente e o pH de 6,1 foi ajustado pela adição de $\mathrm{HCl} 1 \mathrm{M}$. Após o preparo, a solução foi acondicionada em frasco de polietileno e mantida sob refrigeração, até o momento de sua utilização. Ressalta-se ainda, que a solução de SBF apresenta um prazo máximo de validade igual a 30 dias (LOBO, A. O., 2011).

Para o recobrimento, os corpos de prova foram imersos em uma solução $S B F$ de acordo com a norma (ISO-FDIS23317, 2005), usando frasco de polietileno com volume próximo a $50 \mathrm{~mL}$ e acondicionados em incubadora (shaker) modelo MA-420, Marconi, com agitação controlada de $80 \mathrm{rpm}$ e refrigerada à temperatura de $36,5^{\circ} \mathrm{C}$. A troca da solução foi feita a cada 48 horas, não havendo lavagem dos corpos de prova e recipiente, permanecendo na incubadora pelo período de 14 dias. Alguns corpos de prova foram retirados com o período de 7 dias de incubação para que fosse feito algumas caracterizações desse material. Após o período de incubação, os corpos de prova foram removidos dos frascos, lavados com água deionizada e mantidos em dessecador até o momento da caracterização.

\subsection{Incorporação de Estrôncio na camada de fosfatos de cálcio}

Para a incorporação do estrôncio na superfície dos corpos de prova porosos, recobertos com fosfatos de cálcio, foi utilizada a metodologia adotado no trabalho de Pierri e colaboradores (PIERRI, JJ et al., 2007). Para isso preparou-se uma solução contendo água destilada e 100 ppm de $\mathrm{Sr}\left(\mathrm{NO}_{3}\right)_{2}$ de grau analítico em agitador magnético. Em seguida, os corpos porosos recobertos com período de 14 dias de incubação, foram imersos nessa solução (aproximadamente $45 \mathrm{ml}$ ) por $48 \mathrm{~h}$ a $37^{\circ} \mathrm{C}$. 


\subsection{Caracterização dos corpos de prova recobertos com fosfatos de cálcio}

A caracterização dos corpos porosos recobertos com fosfatos de cálcio foi realizada para quantificar e qualificar a presenças dos grupos de fosfatos de cálcio e de $\mathrm{Sr}^{2+}$. Os corpos porosos foram caracterizados com período de incubação de 7 e 14 dias através.

\subsubsection{Medidas do $\mathrm{pH}$ da solução de $S B F$}

Durante o período de recobrimento biomimético, a medida do $\mathrm{pH}$ da cada solução, onde os corpos de prova estavam imersos, era feita a cada 48 horas, quando ocorria a troca da solução de SBF. Essa análise foi realizada para o controle da saturação dos fosfatos de cálcio (LOBO et al., 2013). Foi utilizado o pHmetro WTW, modelo pH3210.

\subsubsection{Espectroscopia de emissão óptica com plasma indutivamente acoplado}

A espectroscopia de emissão óptica com plasma indutivamente acoplado (ICP-OES) foi realizada para quantificar a quantidade de íons presentes de $\mathrm{Ca}^{2+}, \mathrm{P}$ e $\mathrm{Sr}^{2+}$, no recobrimento dos corpos porosos, com período de 14 dias de incubação.

Para isso, a lixiviação dos corpos de prova foi realizada utilizando ácido nítrico e ácido fluorídrico concentrados, na proporção de 1:1, e aquecimento a $90{ }^{\circ} \mathrm{C}$ por $1 \mathrm{~h}$ em bloco digestor com frascos fechados. Em seguida, após resfriar a temperatura ambiente, os corpos de prova foram lavados em $50 \mathrm{ml}$ com água deionizada e mantidos em temperatura ambiente, até o momento da leitura. O Equipamento utilizado foi o Espectrômetro ICP OES, Radial, da marca Spectro, modelo Arcos, com os parâmetros descritos na Tabela 9.

Tabela 9 - Tabela representando os parâmetros utilizados no equipamento para o ensaio de ICP-OES.

\begin{tabular}{l|l}
\hline Parâmetro & Valor \\
\hline Potência aplicada & $1400 \mathrm{~W}$ \\
\hline Radiofrequência do gerador de RF & $27,12 \mathrm{MHz}$ \\
\hline Vazão do gás do plasma & $12 \mathrm{~L} \mathrm{~min}^{-1}$ \\
Vazão do gás auxiliar & $1 \mathrm{~L} \mathrm{~min}^{-1}$ \\
\hline Vazão do gás de nebulização & $0,85 \mathrm{~L} \mathrm{~min}^{-1}$ \\
Vazão de introdução de amostra & $0,85 \mathrm{~L} \mathrm{~min}^{-1}$ \\
Velocidade da bomba & $30 \mathrm{rpm}$ \\
\hline Nebulizador & crossflow \\
\hline
\end{tabular}




\subsubsection{Infravermelho Próximo (NIR)}

As fases formadas de fosfatos de cálcio depositadas na superfície dos corpos porosos, com período de 14 dias de incubação, foram caracterizadas por Infravermelho Próximo (NIR) (NIRS, Perkin Elmer, modelo Spectrum 100N, com acessório de reflectância difusa, NIRA), a partir de 32 espectros e resolução de $16 \mathrm{~cm}^{-1}$. Todos os dados foram tratados matematicamente para correção de linha de base, sendo utilizado o filtro de Savitsky-Golay. Antes do ensaio, os corpos porosos recobertos foram previamente secos a $100{ }^{\circ} \mathrm{C}$, durante 24 horas, para a remoção do excesso de umidade de suas superfícies.

As curvas obtidas foram tratadas com ajuda da função gaussiana, ferramenta matemática para ajustar a deconvolução (fitting), sob os espectros para identificação da concentração de fases de fosfatos de cálcio, nas respectivas contribuições percentuais das combinações dos modos vibracionais dos grupos funcionais presentes.

As bandas fundamentais do infravermelho médio (NIR) têm valores de absortividade elevados, no entanto, a sua combinação correspondente no infravermelho próximo e as bandas de overtones têm a vantagem de uma absorção mais baixa. A informação repetitiva proporcionada pelas várias faixas de tons e de combinação no infravermelho próximo proporciona uma oportunidade para a seleção do comprimento no trajeto apropriado (WORKMAN JR; WEYER, 2012).

A transição do estado fundamental para o segundo estado excitado com a absorção de NIR dá origem a bandas fracas denominadas $1^{\text {a }}$ overtone no NIR. A transição do estado fundamental para o terceiro estado excitado com a absorção do NIR dá origem a bandas fracas chamadas $2 \underline{a}$ overtone no NIR. Tal como as $3 \underline{a}$ e $4 \underline{a}$ bandas de overtones sensíveis ocorrerão com base na transição para o quarto e quinto estado excitado com a absorção de NIR (AENUGU et al., 2011).

\subsubsection{Difratometria de Raios-X}

As caracterização das fases formadas de fosfatos de cálcio e $\mathrm{Sr}^{2+}$ após recobrimento, com período de 14 dias de incubação, foi realizada em um difratômetro de raios-X da marca Rigaku modelo Miniflex 600, com ângulos de varredura de 5 a $80^{\circ}$ e velocidade de varredura do ganiômetro de $0,5 \% \mathrm{~min}$. Foram analisados os seguintes corpos porosos: Alumina $(A)$ e Alumina-Zircônia $(A Z)$ recobertas pelo método biomimético e Alumina $(A(S))$ e Alumina- 
Zircônia $(A Z(S))$, recobertas pelo método biomimético e tratadas em solução com Nitrato de Estrôncio $\left(\mathrm{Sr}\left(\mathrm{NO}_{3}\right)_{2}\right)$.

A função gaussiana foi utilizada como ferramenta matemática para ajustar a deconvolução (fitting) das curvas na região onde encontra-se uma maior concentração de fases de fosfatos de cálcio.

\subsubsection{Microscopia eletrônica de varredura}

O sistema acoplado para microanálise química, por Espectroscopia de Energia Dispersiva de Raio-X (EDS), foi utilizado para análises da superfície dos corpos porosos recobertos biomimeticamente, com período de 7 e 14 dias de incubação, foram avaliadas microestruturalmente utilizando microscopia eletrônica de varredura (MEV) e por espectroscopia de energia dispersiva (EDS), visando quantificar a relação $\mathrm{Ca} / \mathrm{P}$ presente e, usando o mesmo equipamento apresentado no item 4.4.3.

Para verificar o recobrimento na superfície e o quanto foi penetrado nos corpos porosos de fosfatos de cálcio nos poros internos dos corpos porosos, os mesmos foram fraturados e sua superfície de fratura foi analisada por MEV e EDS.

\subsection{Ensaios biológicos in vitro}

\subsubsection{Cultura de células}

A linhagem celular de osteosarcoma humano MG-63 (ATCC ${ }^{\oplus}$ CRL-1427 $^{\text {TM }}$ ) foi utilizada como modelo experimental de regeneração óssea in vitro. As células foram mantidas em meio DMEM (Dulbecco's Modified Eagle Medium - Gibco) suplementado com 10\% de soro fetal bovino (SFB - Gibco) em estufa à $37{ }^{\circ} \mathrm{C}$ e $5 \%$ de $\mathrm{CO}_{2}$.

\section{Ensaio de viabilidade celular}

Para analisar a viabilidade celular após o cultivo das células sobre as amostras por 24 h, utilizamos o kit de ensaio toxicológico in vitro TOX7 (Sigma-Aldrich). Células não viáveis sofrem lise, o que acarreta na liberação da enzima lactato desidrogenase (LDH) no meio de cultura. Essa enzima pode ser mensurada pelo ensaio colorimétrico de LDH liberado. No presente trabalho as células MG-63 foram cultivadas sobre as amostras na concertação de $10^{5}$ 
células por poço em meio sem SFB. Após 24 h, o meio foi retirado e centrifugado a 1500 rpm por 4 min para a sedimentação de qualquer resto celular. O sobrenadante foi submetido ao ensaio toxicológico TOX7 seguindo as especificações do fabricante. A densidade óptica (OD) foi medida em espectofotômetro de placa nos comprimentos de onda de $490 \mathrm{~nm}$ e $690 \mathrm{~nm}$. Os valores apresentados no gráfico são resultados da subtração $\mathrm{OD}_{490}-\mathrm{OD}_{690}$.

Para a realização dos ensaios biológicos in vitro, foi usada uma linhagem celular de osteosarcoma humano MG-63 (ATCC ${ }^{\oplus}$ CRL-1427 ${ }^{\text {TM }}$ ), como modelo experimental de regeneração óssea in vitro, nos corpos de prova porosos. Para isso as células foram mantidas em meio DMEM (Dulbecco's Modified Eagle Medium - Gibco) suplementado com $10 \%$ de soro fetal bovino (SFB - Gibco) em estufa à $37^{\circ} \mathrm{C}$ e $5 \%$ de $\mathrm{CO}_{2}$.

Foram testadas a citotoxicidade dos corpos porosos sem tratamento ( $A$ e AZ) e com tratamento (A-T e AZ-T) superficiais químicos com $\mathrm{H}_{3} \mathrm{PO}_{4}$, e recobertos biomimeticamente com solução de SBF 5,0x (A-T-Rec e AZ-T-Rec). Os corpos porosos recobertos foram esterilizados em autoclaves e os controles positivos (látex) e negativos (papel filtro) por exposição na luz ultravioleta por 24 horas.

\subsection{Coloração vermelha de alizarina}

Os corpos porosos entraram em contato com células MG63 durante 14 dias (em uma placa de 96 poços). Após esse período, de cultura de células, cada poço foi lavado por três vezes usando solução de Hank (Sigma-Aldrich, EUA) a $37^{\circ} \mathrm{C}$ e adicionou-se $70 \%$ de etanol para fixar as células nos corpos porosos ( $1 \mathrm{~h}$ a $4{ }^{\circ} \mathrm{C}$ ). Em seguida, os corpos porosos foram lavados duas vezes (PBS) e corados durante 15 min usando vermelho de Alizarina ( $2 \%$, pH 4,2, Sigma-Aldrich, St Louis MO, EUA) a $37^{\circ} \mathrm{C}$. Para finalizar o processo de lavagem, foi utilizado água deionizada e depois foram secas durante $24 \mathrm{~h}$ a $37^{\circ} \mathrm{C}$.

A formação do nódulo mineralizado como osso foi visualizada por microscópio de luz invertida (Zeiss Microlmaging GmbH Carl Microscope - Axiovert 40C, Alemanha). Em seguida, o corante foi extraído e foram adicionados $560 \mu \mathrm{L}$ de ácido acético (10 \%) e $40 \mu \mathrm{L}$ de hidróxido de amônia (10 \%) para neutralizar. Após a extração do corante, a absorvância foi medida usando um espectrofotômetro (405 nm, EL808IU, Biotek Instruments, Winooski, EUA). Esta medida é proporcional à deposição de cálcio de células MG63. Os valores foram expressos como densidade óptica. 


\section{Análise estatística}

O ensaio de LDH liberado foi realizado com um " $n$ " amostral igual a 6, onde os resultados obtidos estão expressos como média \pm desvio padrão da média. Os dados foram submetidos a teste de normalidade Kolmogorov-Smirnov e análise de variância (ANOVA) com pós teste Holm-Sidak's utilizando o programa GraphPad Prism 6.0. O nível de significância para rejeição da hipótese de nulidade foi fixado em $5 \%$ ( $p<5 \%$ ).

\subsection{Formação e quantificação dos nódulos de mineralização}

A formação de nódulos de mineralização foi avaliada após 14 dias de cultura ( $n=5$ para cada grupo experimental). Para tanto, as células aderidas foram fixadas em solução de formol $10 \%$ por 2 horas à temperatura ambiente. Após fixação, as amostras foram desidratadas com uma série gradual de álcool e coradas com vermelho de Alizarina S $2 \%$ (Sigma-Aldrich, St. Louis, Brasil), pH 4,2 por 10 minutos. O corante vermelho de Alizarina S cora áreas que são ricas em cálcio.

A quantificação das formações mineralizadas foi realizada de acordo com o método descrito de Gregory (GREGORY et al., 2004). A leitura foi realizada em leitor de microplaca 59 (Biotek - EL808IU, USA), sob o comprimento de onda de $405 \mathrm{~nm}$. 


\section{RESULTADOS E DISCUSSÃO}

Neste capítulo, serão apresentados os resultados e discussões obtidas nas caracterizações físicas, microestruturais e mecânica dos corpos porosos de alumina (designado por $A$ ) e alumina contendo 5 em volume de inclusões nanométricas de zircônia (designado por $A Z$ ) antes e após recobrimento biomimético. Os corpos porosos tratados quimicamente com $\mathrm{Sr}^{2+}$, são designados como, $A(\mathrm{~S})$ corpos porosos de alumina, e $A Z(\mathrm{~S})$ corpos porosos de alumina contendo 5 \% em volume de inclusões nanométricas de zircônia.

\subsection{Caracterização física, microestrutural e mecânica dos corpos porosos}

A Tabela 10 apresenta os valores de porosidade aparente, dados em porcentagem de densidade teórica (\%DT), medida percentual da retração linear e compressão axial, dos corpos porosos de alumina e alumina-zircônia.

Tabela 10 - Resultados dos ensaios de Retração linear, porosidade aparente e resistência à compressão axial dos corpos porosos.

\begin{tabular}{c|c|c|c}
\hline $\begin{array}{c}\text { Corpos } \\
\text { porosos }\end{array}$ & $\begin{array}{c}\text { Retração linear } \\
\text { (\%) }\end{array}$ & $\begin{array}{c}\text { Porosidade aparente } \\
\text { (\%DT) }\end{array}$ & $\begin{array}{c}\text { Resistência à } \\
\text { compressão (MPa) }\end{array}$ \\
\hline A & $17,03 \pm 0,46$ & $80,93 \pm 0,02$ & $2,93 \pm 0,11$ \\
AZ & $16,21 \pm 0,76$ & $78,82 \pm 0,04$ & $6,59 \pm 0,35$ \\
\hline
\end{tabular}

Os resultados obtidos de porosidade, para os corpos porosos de alumina e aluminazircônia, foram de 80,93 \% e 78,82 \%, respectivamente. Essa diferença de porosidade pode ser devido ao processo de impregnação da esponja na barbotina. Os valores encontrados de porosidade aparente, quando produzidas pelo método da réplica, são próximos da literatura (COSTA et al., 2008), que apresentam valores de $76-78 \%$ e, sendo que algunsoutros trabalhos apresentam porosidade superior a 80 \% (ACCHAR, W et al., 2009; RAMALHO, 2012). Como os pós da barbotina de alumina-zircônia, tinham uma área superficial maior e a quantidade dos compostos usadas na preparação dessa barbotina foram os mesmos, os poros da esponja eram fechados antes de passarem pela calandra resultando num valor de porosidade menor.

Os valores obtidos nos ensaios de compressão axial, foram de 2,928 MPa e 6,591 MPa para a alumina e alumina-zircônia, respectivamente. Esse valor é devido à alta porosidade encontrada, principalmente para a alumina. Para o tecido ósseo esponjoso, é encontrado na literatura, valores de 2-12 MPa e para o tecido osso compacto de 100-230 MPa (GARTNER; 
HIATT, 2011; SANTANA-MELO et al., 2017; TORTORA; DERRICKSON, 2016). Os corpos porosos de alumina e alumina-zircônia estão na faixa de resistência mecânica do tecido ósseo poroso, sugerindo este material, para substituição ou preenchimento ósseo.

A Figura 10 apresenta as micrografias, obtidas por MEV, da superfície de fratura dos corpos porosos de alumina.

Figura 10 - Micrografias obtidas por MEV da superfície de fratura do corpo poroso de alumina mostrando: (a) e (b) morfologia dos poros, (c) interconectividade.

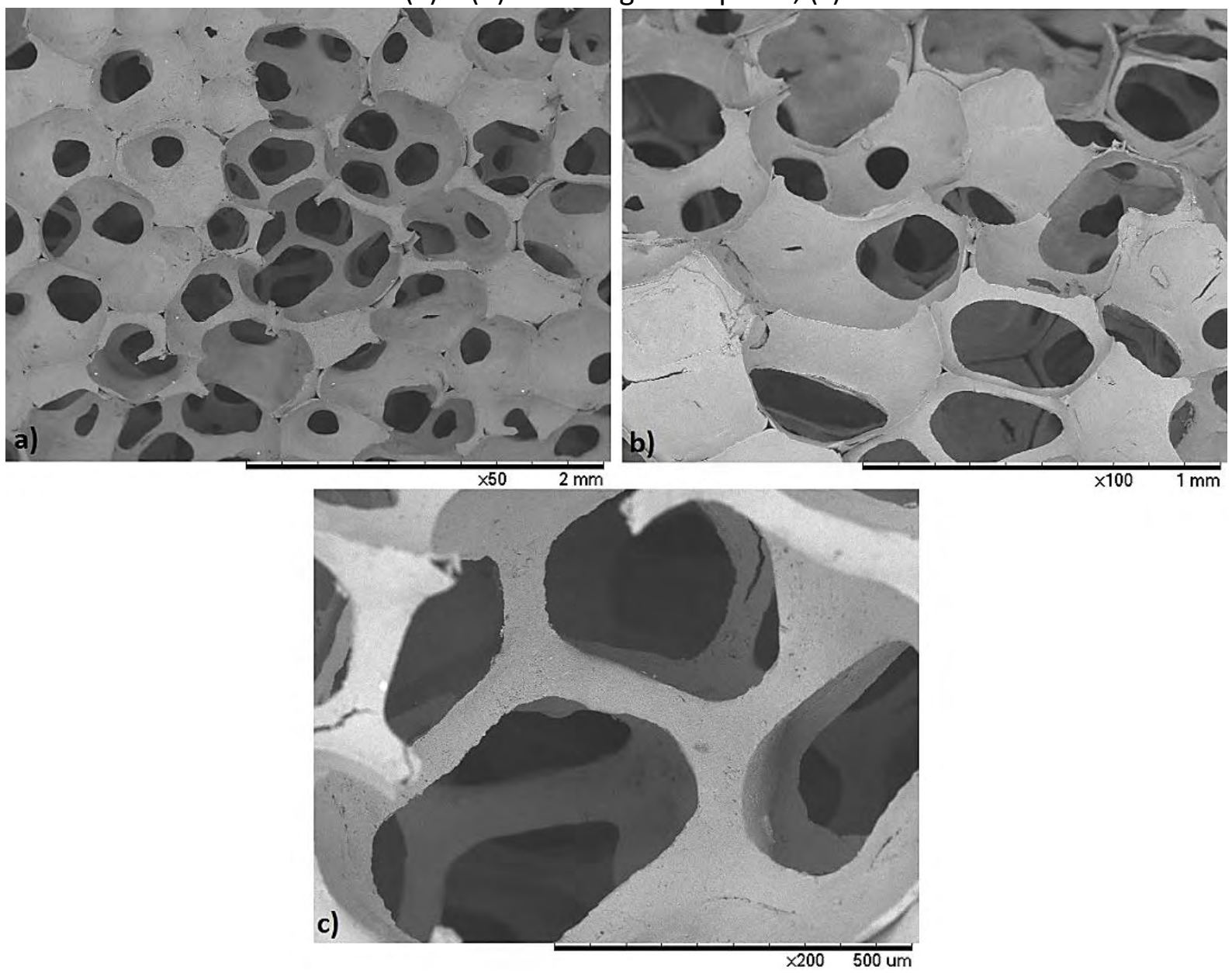

Pode-se observar, na micrografia da Figura 10 (a) uma boa distribuição espacial de poros, e nas micrografias Figura 10 (b) e (c) poros menores localizados dentro de poros maiores. Além disso, verifica-se uma interconectividade entre os poros, representada pela ligação entre poros vizinhos na Figura 10 (c). A morfologia de poros interligados é de extrema importância em implantes para o crescimento e transporte celular através dos mesmos e passagem de nutrientes para manutenção e renovação dos tecidos. 
A Figura 11 apresenta as micrografias da superfície polida dos corpos porosos de alumina.

Figura 11 - Micrografias obtidas por MEV da superfície polida do corpo poroso de alumina mostrando: (a) e (b) morfologia dos poros, (c) interconectividade dos poros.

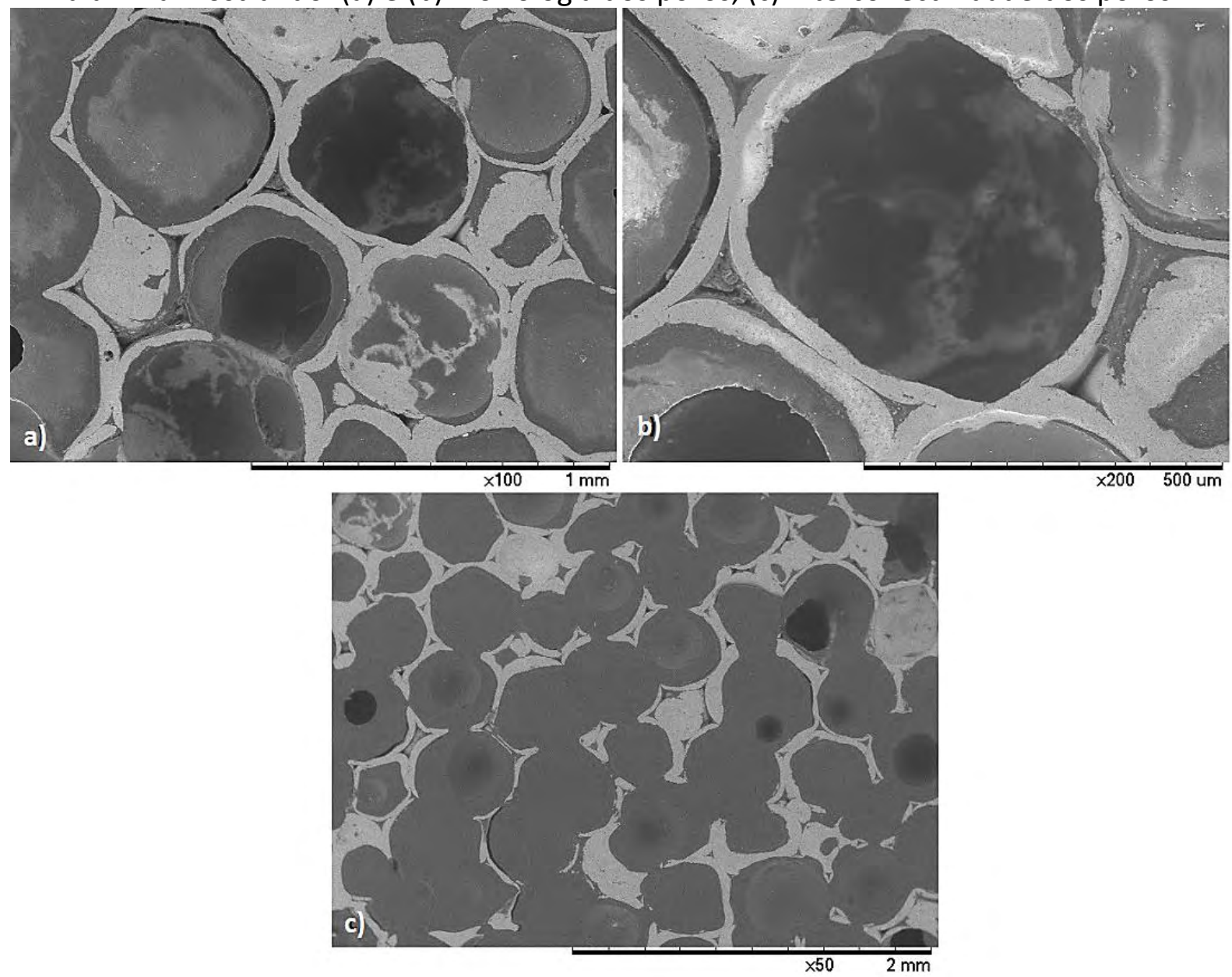

Através das micrografias pode-se observar com mais detalhes o formato esférico dos poros e a interconectividade entre eles. Na Figura 11 (c) observa-se a condição requerida para orientar e controlar o crescimento ósseo no interior do implante.

A Figura 12 apresenta a superfície de fratura do corpo poroso de Alumina, mostrando no destaque, Figura 12 (b), que no interior os corpos porosos mantêm sua morfologia de poros interconectados e arredondados, de ótima permeabilidade, como em sua superfície. 
Figura 12 - (a) Micrografias obtidas por MEV da superfície de fratura nos corpos porosos de Alumina, (b) Micrografia com aumento destacando o aumento com sua interconectividade e os vazios triangulares.

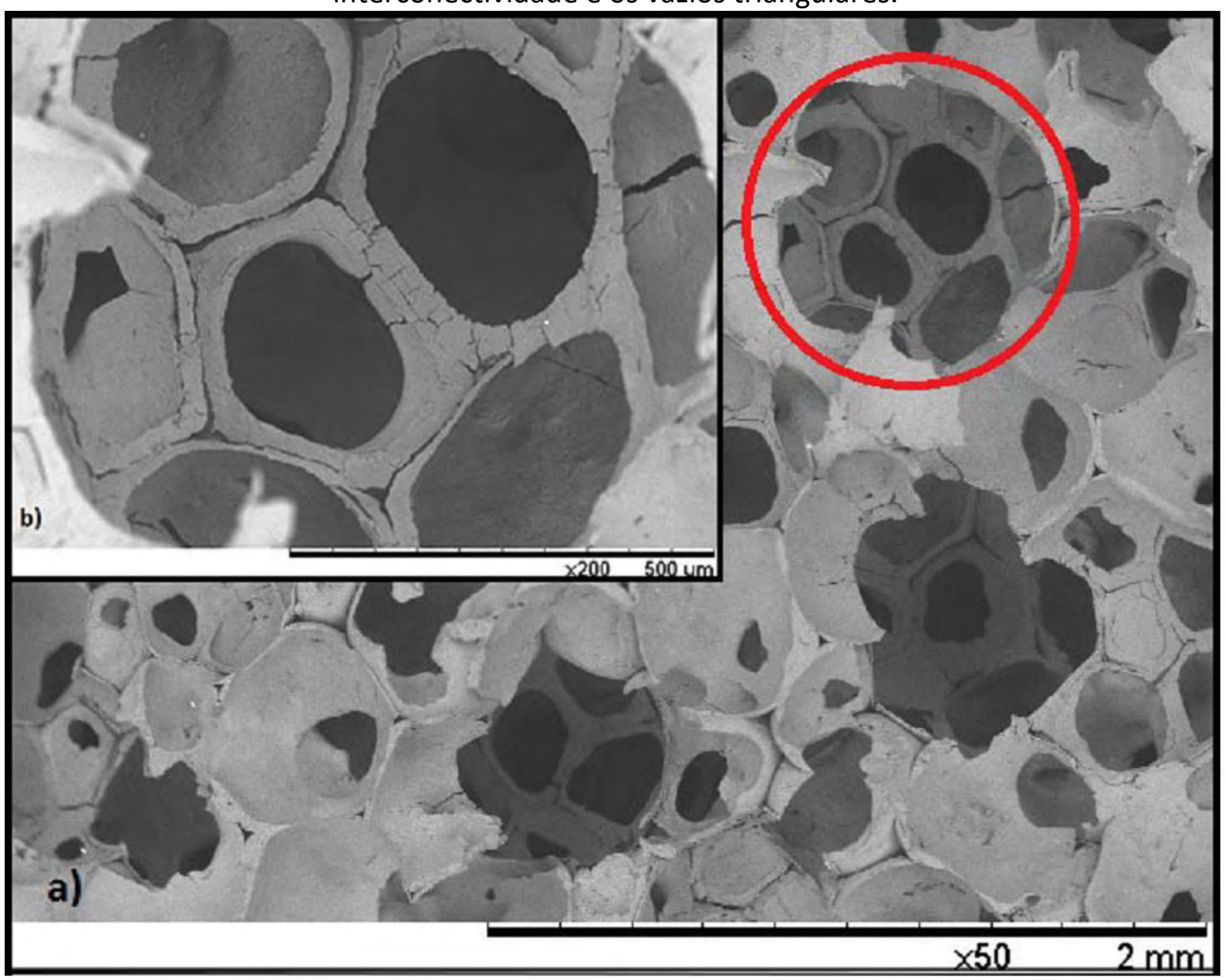

Observa-se também, microtrincas em sua superfície decorrentes do processo de fabricação e presença de vazios triangulares no seu interior ocasionado pela decomposição da esponja. Esses defeitos na forma de vazios triangulares e a presença de microtrincas podem ter contribuídos para os baixos valores obtidos nos ensaios de compressão axial.

A Figura 13 mostra as micrografias da superfície de fratura dos corpos porosos de alumina-zircônia, onde pode-se observar boa distribuição espacial de poros. 
Figura 13 - Micrografias obtidas por MEV da superfície de fratura do corpo poroso de Alumina-Zircônia mostrando: (a) e (b) morfologia dos poros, (c) interconectividade dos
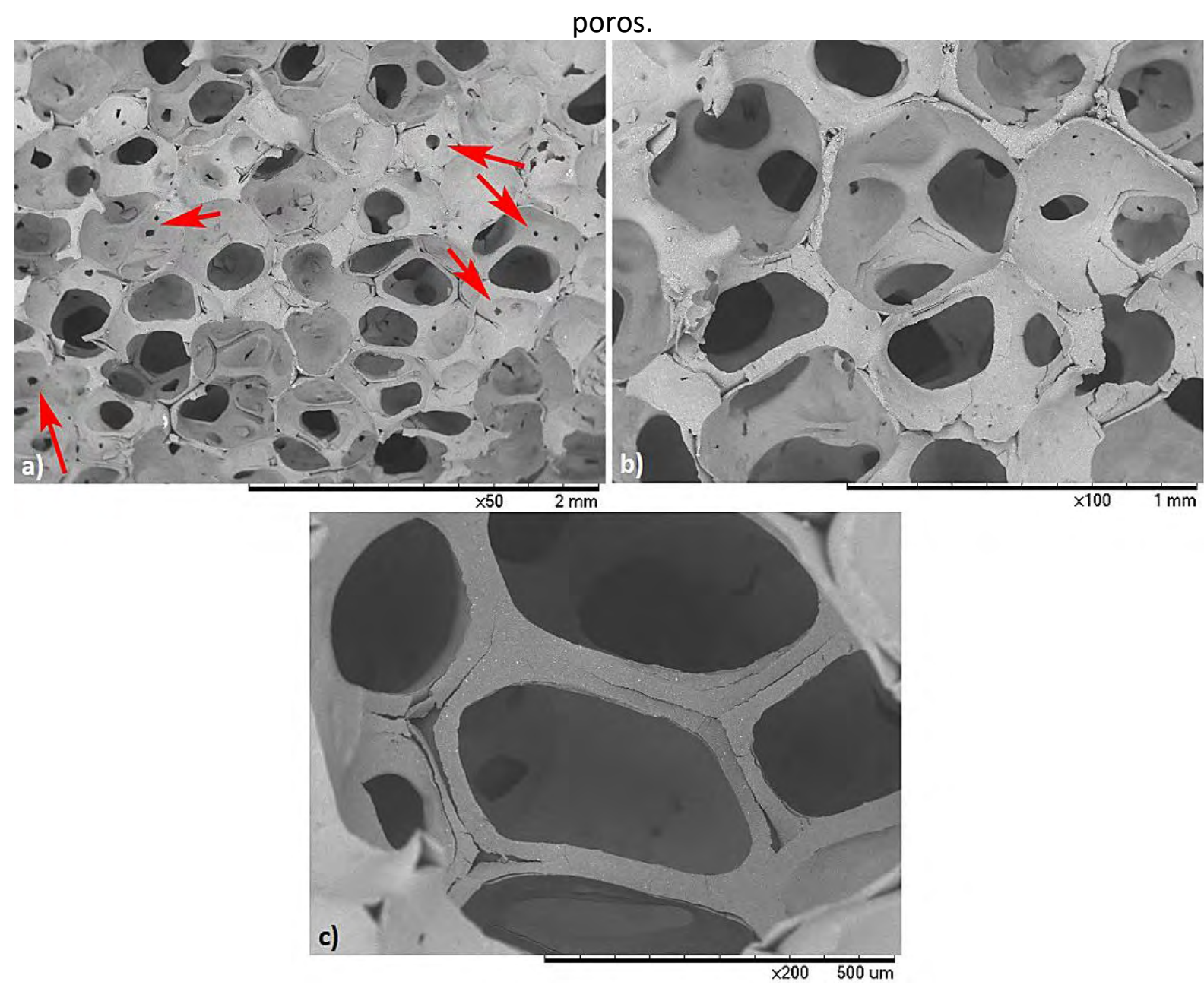

Os poros são caracterizados majoritariamente pelo formato esférico, existindo, como indicado na Figura 13 (a) e (b), uma maior quantidade de poros menores em sua superfície, em comparação com os resultados obtidos nos corpos porosos de Alumina (Figura 9). Nas micrografias da Figura 13 (b) e (c), pode-se observar também uma interconexão entre os poros e a presença de vazios triangulares, que é o resultado da decomposição da esponja polimérica.

A micrografia dos corpos porosos de alumina-zircônia, apresentada da Figura 14 (a) indica uma grande quantidade de poros menores em sua superfície em comparação com os resultados obtidos nos corpos porosos de alumina na Figura 9, também podem ser observadas nas micrografias da superfície polida destacada com maior aumento, nas Figura 14 (b) e (c) uma interconectividade entre esses poros. 
Figura 14 - Micrografias obtidas por MEV da superfície polida do corpo poroso de Alumina-Zircônia mostrando: (a) e (b) morfologia dos poros, (c) interconectividade dos
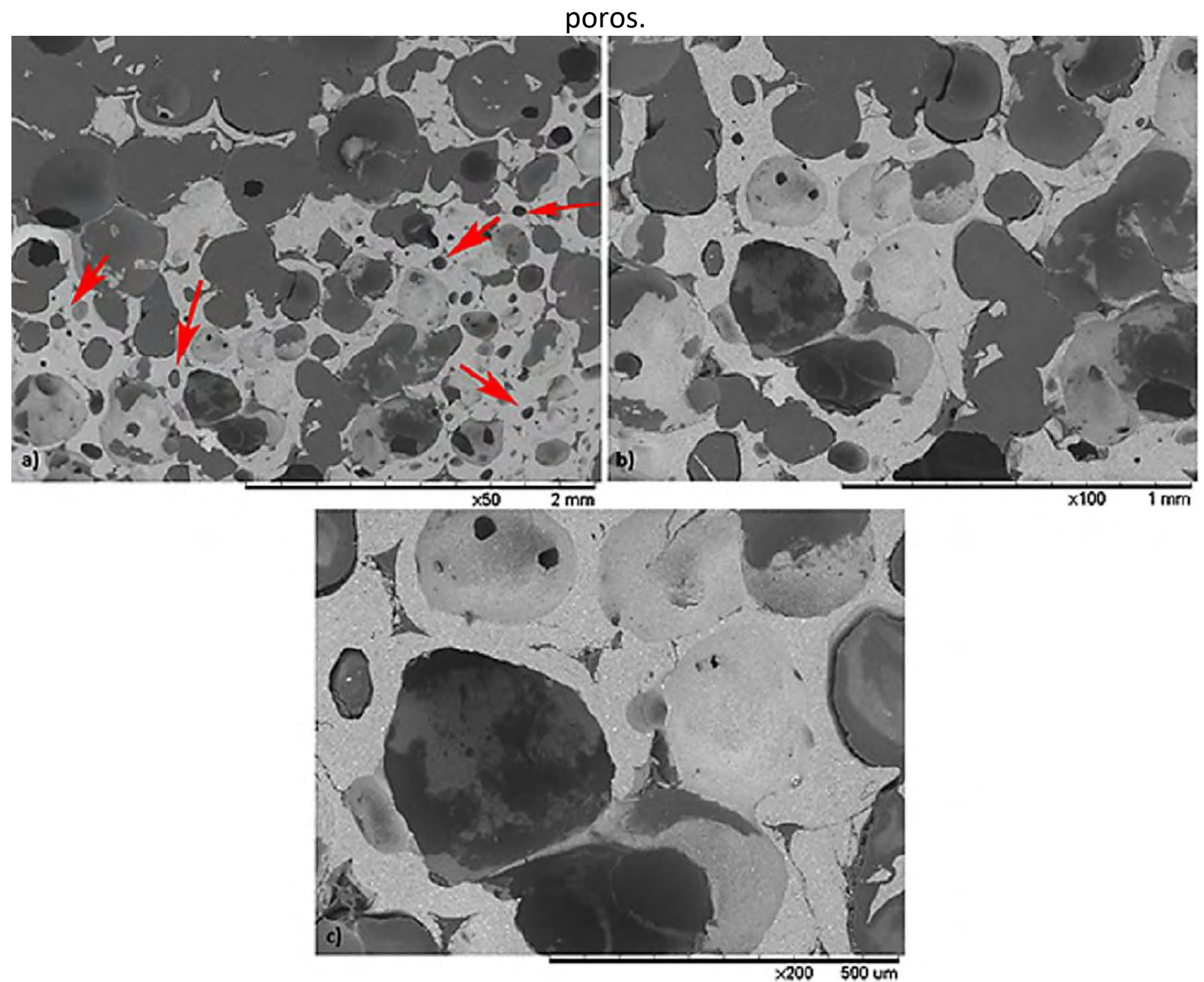

É confirmado, através das micrografias, uma grande interconectividade entre os poros com diversos tamanhos e, e uma grande quantidade de poros menores de formato arredondado em sua superfície, em comparação com os resultados obtidos nos corpos porosos de Alumina.

Na micrografia da Figura 15 (a) e (b), pode ser observado a superfície de fratura dos corpos porosos de alumina-zircônia. Observa-se que em seu interior mantêm sua morfologia de poros interconectados e arredondados, como em sua superfície, porém, com poros visualmente menores que os corpos porosos de alumina. 
Figura 15 - (a) Micrografias obtidas por MEV da superfície de fratura do corpos porosos de alumina-zircônia. (b) Micrografia com aumento destacando a interconectividade e os vazios triangulares.

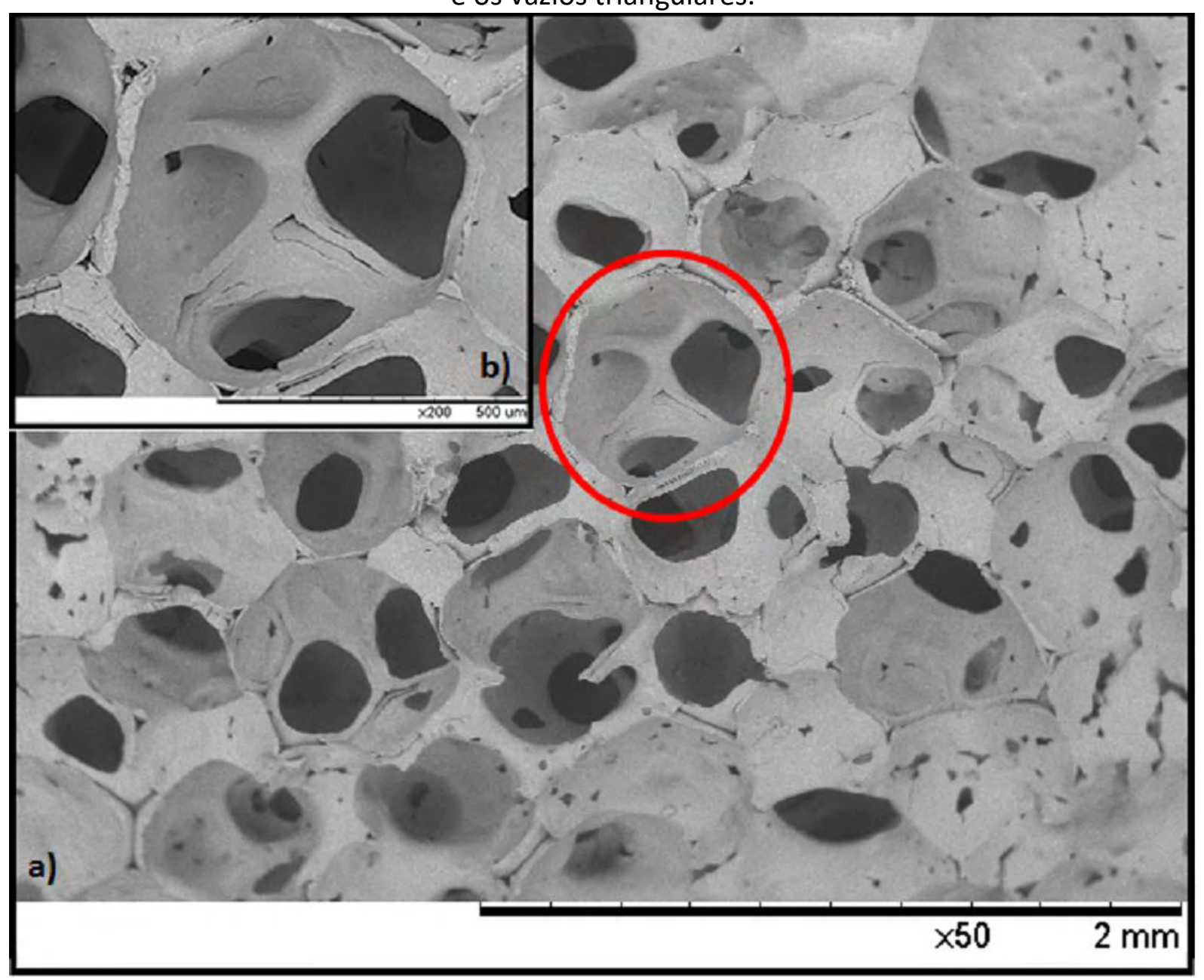

Também, no destaque da imagem da Figura 15 (b) observa-se microtrincas em sua superfície, decorrentes do processo de fabricação e presença de vazios triangulares no seu interior ocasionado pela decomposição da esponja.

A Figura 16 apresenta as micrografias obtidas em um MEV do corpo poroso de alumina-zircônia, onde se observa que as inclusões de zircônia (regiões mais claras) estão dispersas uniformemente na alumina, Figura 16 (b). 
Figura 16 - Micrografias obtidas por MEV destacando o tamanho e distribuição dos grãos de alumina-zircônia.

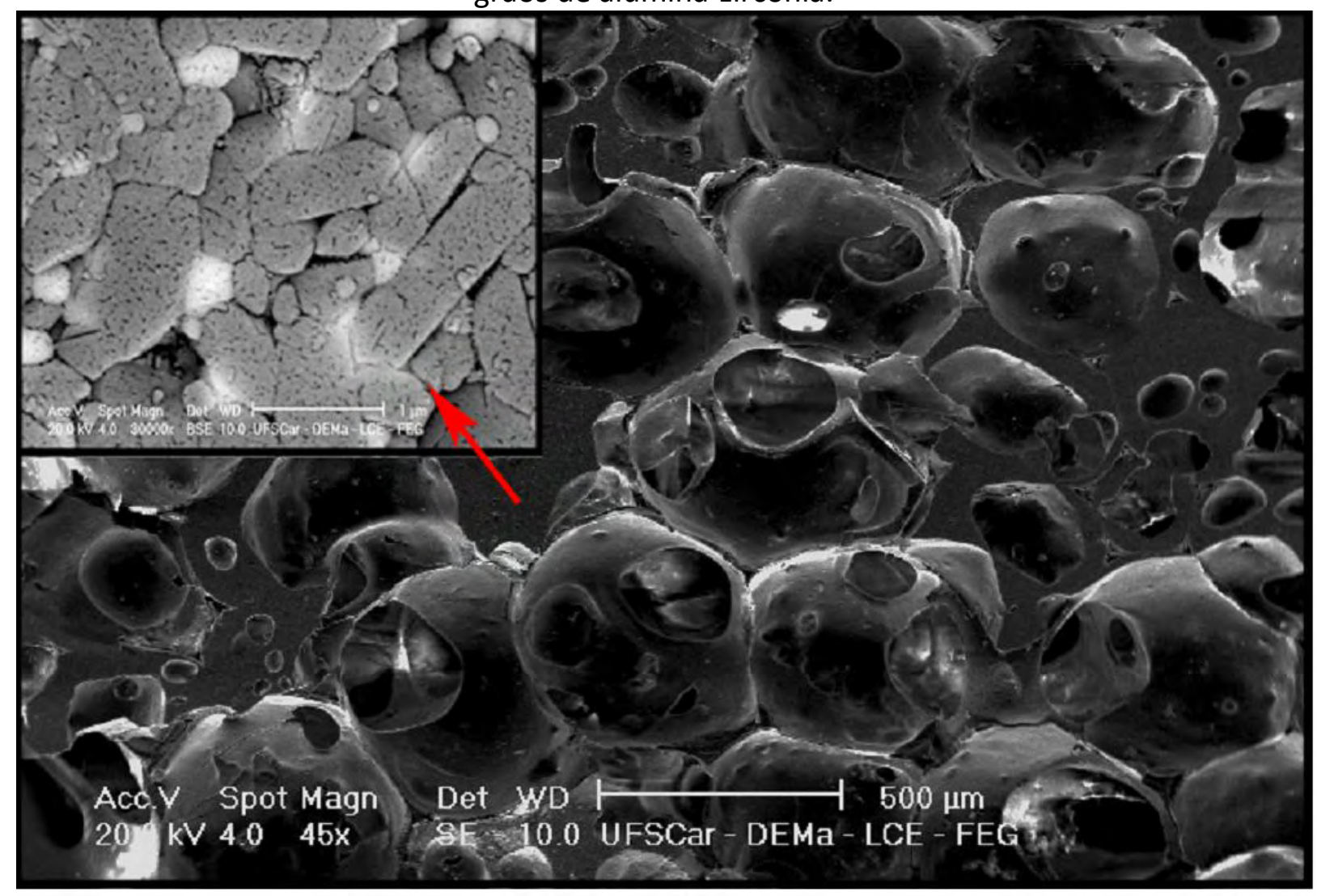

Essa dispersão das inclusões demonstra que a metodologia utilizada foi efetiva para evitar a formação de aglomerados de partículas de zircônia. Considera-se ainda que as inclusões de zircônia estão localizadas nos contornos de grãos da matriz de alumina, inclusive em pontos tríplices.

As Figura 17 e 18 apresentam, respectivamente, imagens dos corpos porosos de alumina e alumina-zircônia, onde (a) apresenta imagens tridimensionais (3D) na forma cilíndrica com diâmetro de $8,85 \mathrm{~mm}$, (b) e (c) imagens bidimensionais (2D) obtidas pela técnica de microtomografia computadorizada de raios $X(\mu \mathrm{CT})$. Essas seções fornecem informações sobre o perfil morfológico dos corpos porosos, tamanho e distribuição dos poros, bem como a formação e interconectividade entre os poros em toda a amostra. 
Figura 17 - (a) Imagem microtomográfica tridimensional do corpo poroso de alumina, obtida através de $\mu \mathrm{CT}$. (b) e (c) Perfil morfológico bidimensionais.

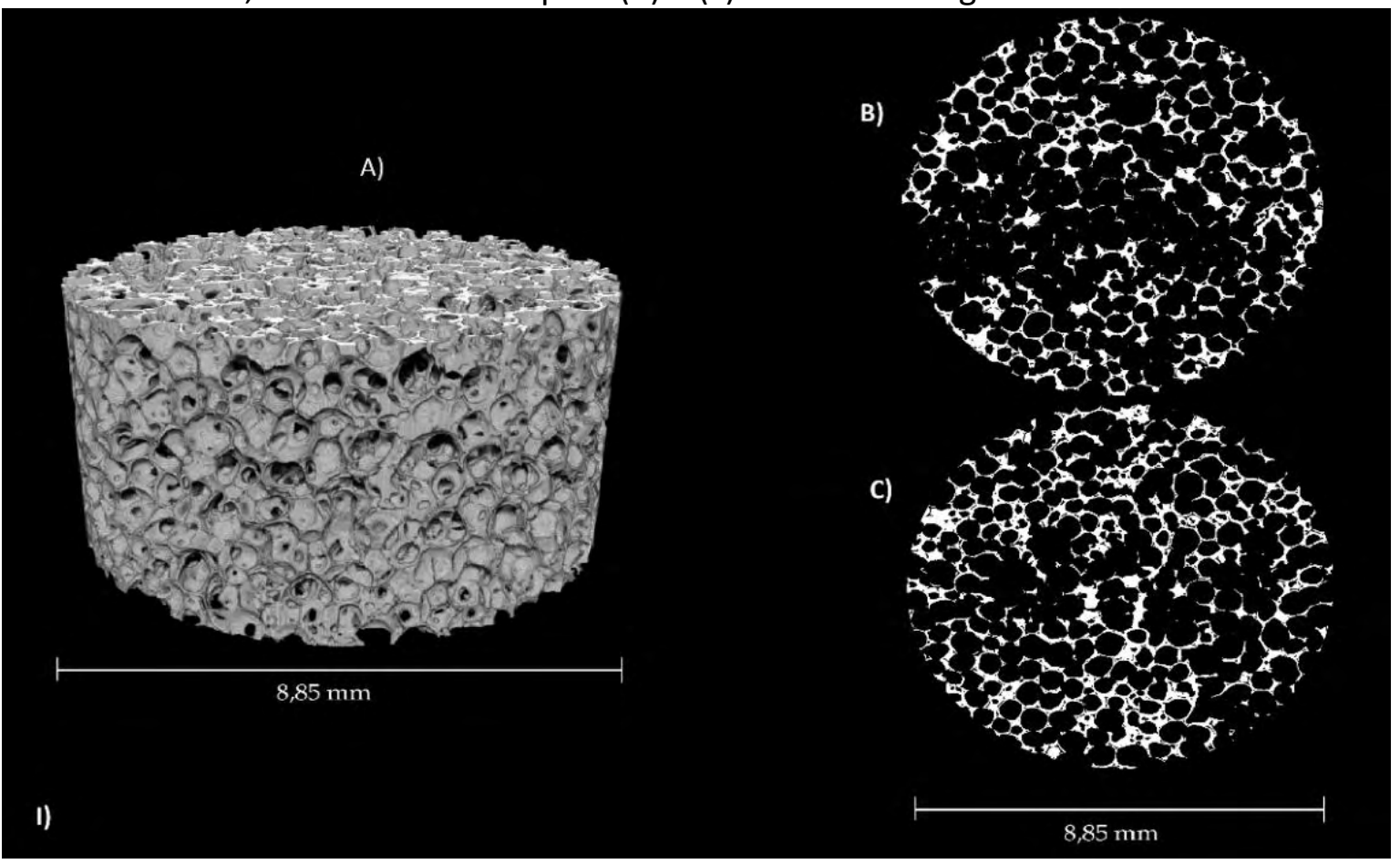

Figura 18 - (a) Imagem microtomográfica tridimensional do corpo poroso de aluminazircônia, obtida através de $\mu \mathrm{CT}$. (b) e (c) Perfil morfológico bidimensionais.

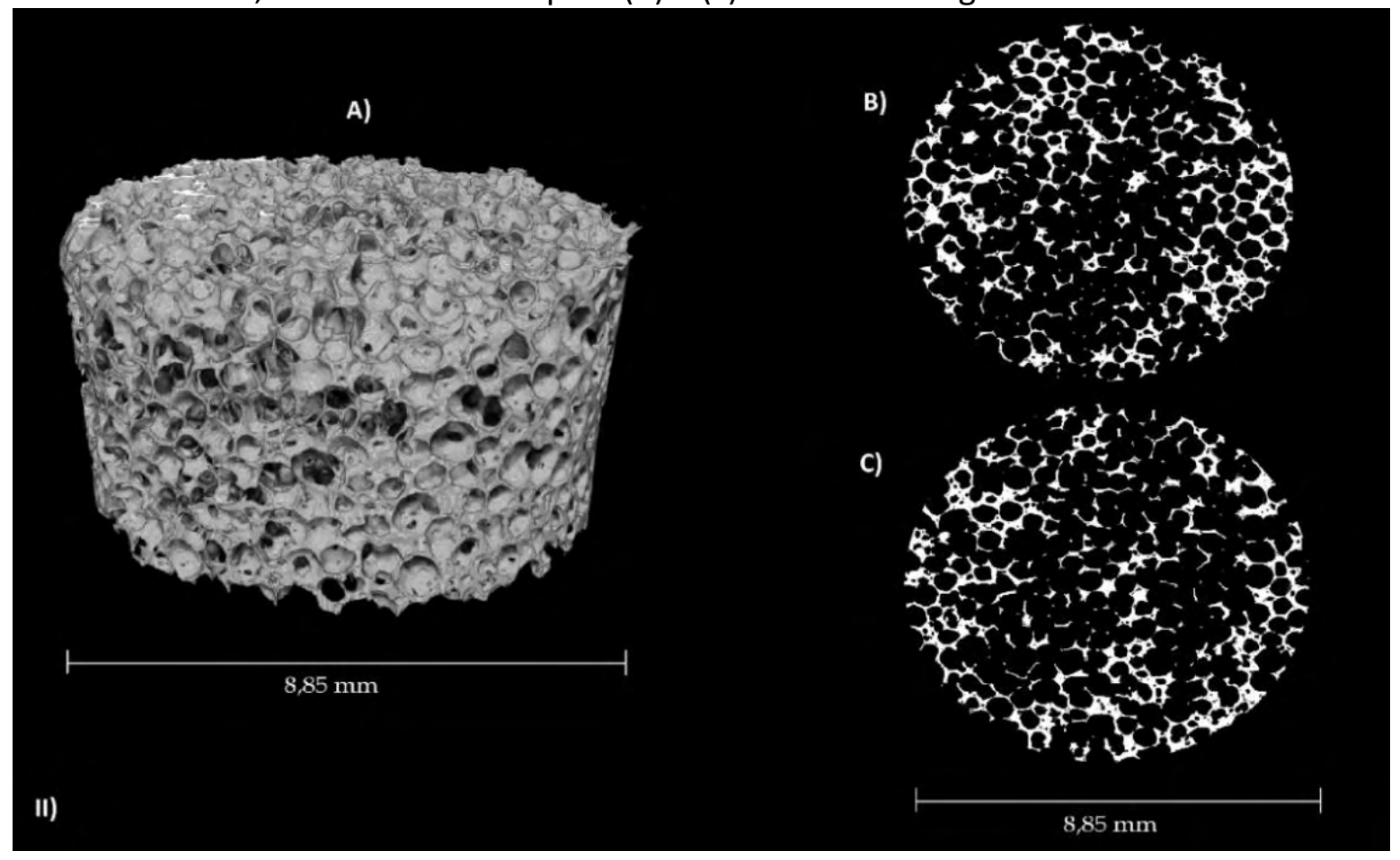

Através das imagens, não destrutiva do corpo poroso obtidas por $\mu \mathrm{CT}$ e reconstruída em 3D, pode-se revelar detalhes morfológicos internos (PETIT et al., 2016). Pôde-se observar, 
através das seções apresentadas, informações sobre o perfil morfológico dos poros, bem como a formação de poros arredondados e interligados em uma distribuição uniforme.

A Figura 19 apresenta o gráfico da distribuição do tamanho dos poros, obtida através da microtomografia computadorizada de raios $X$ dos corpos porosos de alumina e aluminazircônia.

Figura 19 - Gráfico representando a distribuição de tamanho de poros, obtido através da $\mu \mathrm{CT}$, dos poros dos corpos porosos de alumina e alumina-zircônia.

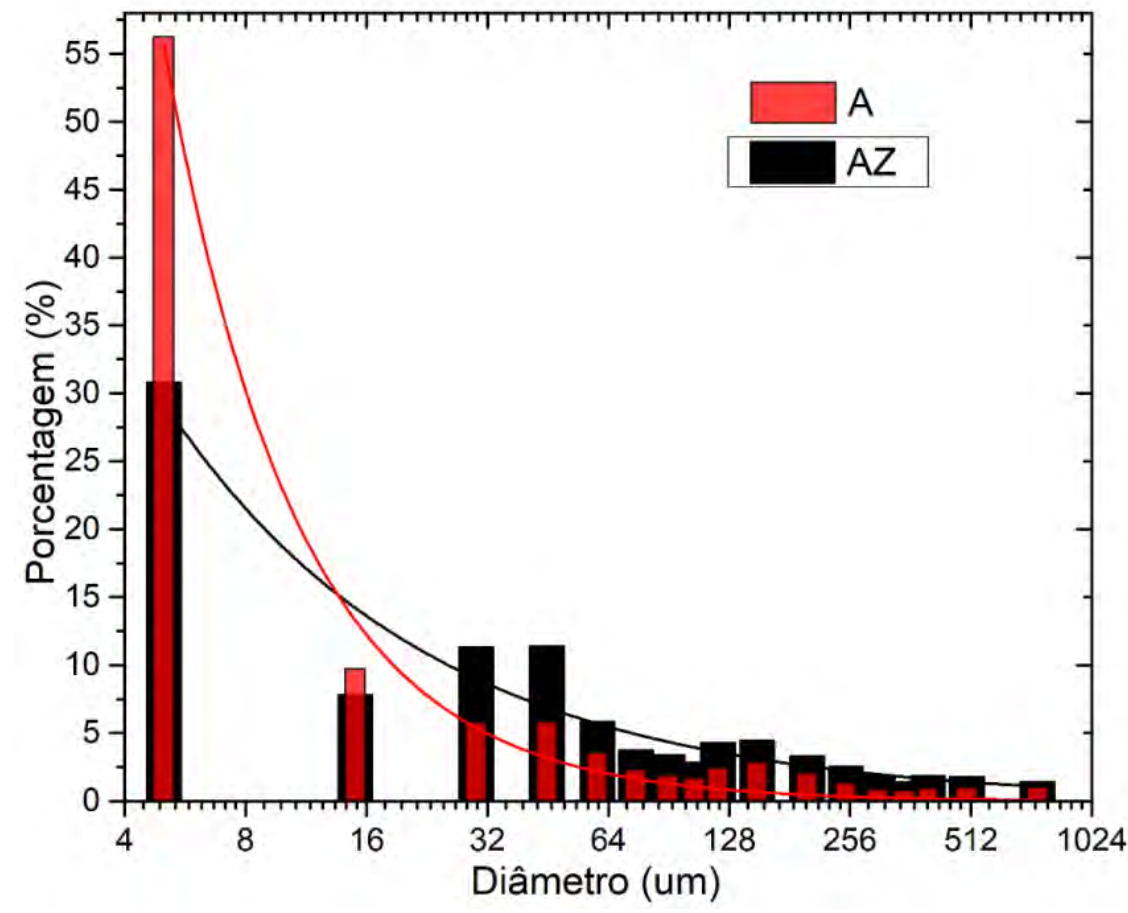

Através da distribuição de poros observada na Figura 18, percebe-se os corpos porosos de $A Z$, apresentam uma ampla faixa de diâmetros de poros, contemplando os de interesse biológico destinados à regeneração do tecido ósseo, enquanto que para de $A$ essa faixa é menor (GÓMEZ, S. et al., 2016; SABREE et al., 2015).

Na Tabela 11, é apresentada a porcentagem de tamanho de poros encontrada para os corpos porosos de alumina e alumina zircônia e suas finalidades relacionadas ao favorecimento biológico. 
Tabela 11 - Frequência relativa de poros dos corpos porosos de Al e Al-Zr representada pela percentagem e sua finalidade.

\begin{tabular}{|c|c|c|c|c|c|}
\hline \multicolumn{2}{|c|}{$\begin{array}{l}\text { Favorecimento } \\
\text { Biológico }\end{array}$} & \multirow[t]{2}{*}{$\begin{array}{c}\text { Tamanho de poros } \\
(\mu \mathrm{m})\end{array}$} & \multicolumn{2}{|c|}{$\begin{array}{c}\text { Frequência } \\
\text { relativa de poros } \\
\text { encontrado (\%) }\end{array}$} & \multirow[t]{2}{*}{ Referências } \\
\hline & & & $A$ & $A Z$ & \\
\hline \multicolumn{2}{|c|}{$\begin{array}{l}\text { Crescimento de } \\
\text { fibroblastos }\end{array}$} & $5-15$ & 65,91 & 38,64 & Klawitter et al., 1971 \\
\hline \multicolumn{2}{|c|}{$\begin{array}{l}\text { Crescimento de } \\
\text { osteóides e } \\
\text { osteointegração }\end{array}$} & $45-100$ & 13,52 & 24,42 & Klawitter et al., 1971 \\
\hline \multirow{2}{*}{ 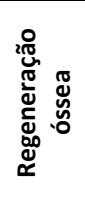 } & $\begin{array}{c}\text { Proliferação de } \\
\text { osteoblastos }\end{array}$ & $100-250$ & 10,28 & 17,36 & $\begin{array}{l}\text { Shao et al., } 2015 \\
\text { Cranin et al., } 1985\end{array}$ \\
\hline & Osteocundução & $250-350$ & 1,62 & 5,74 & $\begin{array}{l}\text { Shao et al., } 2015 \\
\text { Cranin et al., } 1985\end{array}$ \\
\hline \multicolumn{2}{|c|}{$\begin{array}{l}\text { Crescimento de osso, } \\
\text { vascularização, } \\
\text { migração e transporte }\end{array}$} & $<350$ & 2,93 & 6,42 & $\begin{array}{l}\text { Shao et al., } 2015 \\
\text { Cranin et al., } 1985\end{array}$ \\
\hline
\end{tabular}

A partir dos resultados apresentados na Figura 17 e Tabela 11, é possível diferenciar, com base no comportamento regenerativo e formação de tecido ósseo, diferentes grupos de distribuição de tamanho de poro nos corpos porosos de acordo com faixas de diâmetro específico: poros com diâmetros de 5 a $15 \mu \mathrm{m}$, estão relacionados com o crescimento de fibroblastos; poros com diâmetros de 15 a $120 \mu$ m, podem contribuir para o crescimento de hepatócitos (KLAWITTER et al., 1971); poros com diâmetros entre 100 e $250 \mu \mathrm{m}$ estão relacionados à proliferação de osteoblastos (CRANIN, A NORMAN, 1985; SHAO et al., 2015); poros com diâmetros entre 250 e 350 m favorecem a osteocondução (Cranin et al., 1985; SHAO et al., 2015); poros com diâmetros entre 120 e $350 \mu \mathrm{m}$, englobando a faixa citada anteriormente, favorecem eventos relacionados ao crescimento do tecido ósseo; e poros com diâmetros superiores a $500 \mu \mathrm{m}$ podem suportar a rápida vascularização do tecido fibrovascular (LIU, P.; CHEN, 2014).

Através da análise de $\mu \mathrm{CT}$ também pode-se obter o valor da porosidade aberta, sendo que os valores encontrados foram de $81,16 \% \pm 1,35$ para a Al 82,12 $\pm 2,36$ para a AL-Zr. Esses valores ficaram próximos aos obtidos pelo princípio de Arquimedes.

Através dos resultados obtidos na Figura 19 e Tabela 11, verifica-se que 94,26 \% dos poros obtidos nos corpos porosos de alumina, apresentam-se na faixa de tamanho de poros 
desejáveis para o favorecimento de eventos biológicos da formação de tecido ósseo enquanto 92,58 \% dos poros obtidos nos corpos porosos de alumina-zircônia.

\subsection{Corpos porosos recobertas com Fosfatos de Cálcio}

A Tabela 12 apresenta os valores de porosidade aparente obtidos pelo princípio de Arquimedes para os corpos porosos de $A$ e $A Z$ recobertos com fosfatos de cálcio usando o método biomimético, com período de incubação de 14 dias. Observa-se que os resultados de porosidade aparente apresentados na Tabela 10 para os corpos porosos sem recobrimento, se aproximam dos valores apresentados na Tabela 12 para os corpos porosos recobertos. Observa-se também uma ligeira diminuição da porosidade devido ao recobrimento dos poros com fosfatos de cálcio.

Tabela 12 - Porosidade Aparente (\%) dos corpos porosos de alumina e aluminazircônia recobertos pelo método biomimético.

\begin{tabular}{|c|c|c|}
\hline & $\begin{array}{r}\mathbf{P} \\
\text { apz }\end{array}$ & $\begin{array}{l}\text { rosidade } \\
\text { ente (\%DT) }\end{array}$ \\
\hline \multirow{2}{*}{$\begin{array}{l}\text { Corpos porosos } \\
\text { recobertos }\end{array}$} & $A$ & $79,69 \pm 0,03$ \\
\hline & $A Z$ & $76,04 \pm 0,06$ \\
\hline
\end{tabular}

A Figura 20 apresenta os resultados das medidas do pH da solução de SBF realizada a cada troca de solução (48 horas) quando do recobrimento biomimético. Essa medida foi realizada utilizando a solução de cada corpo de prova em imersão.

Figura 20 - Gráfico representando a medida de $\mathrm{pH}$ realizada a cada $48 \mathrm{~h}$ nas soluções de SBF $5 x$, dos corpos porosos de alumina e alumina-zircônia.

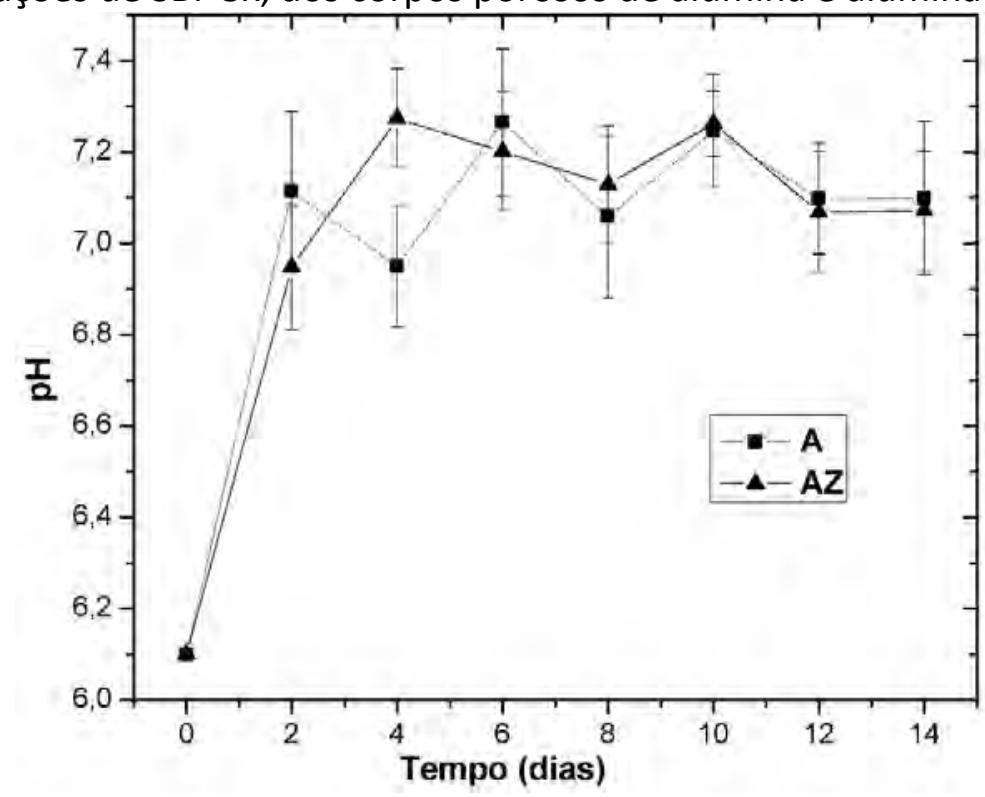


Conforme pode-se observar, após dois dias de imersão, com a troca de solução prevista no recobrimento biomimético, ocorreu uma maior reatividade com a superfície recoberta (LOBO et al., 2013). Esse aumento do pH ocorre devido a deposição nucleada de apatita por precipitação na superfície depositada, pois a solução apresenta-se instável, sendo ela reabsorvida, semelhante a apatita biológica do osso (LOBO et al., 2013). Após 7 dias de imersão, os valores de pH permanecem constantes confirmando sua estabilidade. Isso ocorre devido a troca iônica de $\mathrm{Ca}$ com $\mathrm{H}^{+}$e $\mathrm{H}_{3} \mathrm{O}$. Esse fenômeno ocorre no primeiro dia de imersão na solução SBF, o que resulta, depois de 14 dias, a constante precipitação, para a formação de fases de fosfatos de cálcio e formação de hidroxiapatita carbonatado, como visto em diversos trabalhos (HASHMI; SHAH, 2014; LOBO et al., 2013).

As Figura 21e 22 apresentam, respectivamente os espectros de absorção de NIR, com deconvolução das bandas, no intervalo de 4200 a $5400 \mathrm{~cm}^{-1}$, das superfícies dos corpos porosos de alumina (Al) e com substituição iônica do $\left.\mathrm{Sr}^{2+}(A(S))\right)$ e alumina-zircônia $(A Z)$ e com substituição iônica do $\mathrm{Sr}^{2+} A Z(S)$, tratados com $\mathrm{H}_{3} \mathrm{PO}_{4}$ e recobertos biomimeticamente com SBF 5x após 14 dias de incubação. A região entre 4200 a $5400 \mathrm{~cm}^{-1}$ na análise foi escolhida devido à menor interferência das bandas de absorção da água nesta região.

Figura 21 - Espectros de absorbância de NIR, na região entre 4200 a $5400 \mathrm{~cm}^{-1}$, das superfícies dos corpos porosos de alumina (A) e com substituição iônica (B).
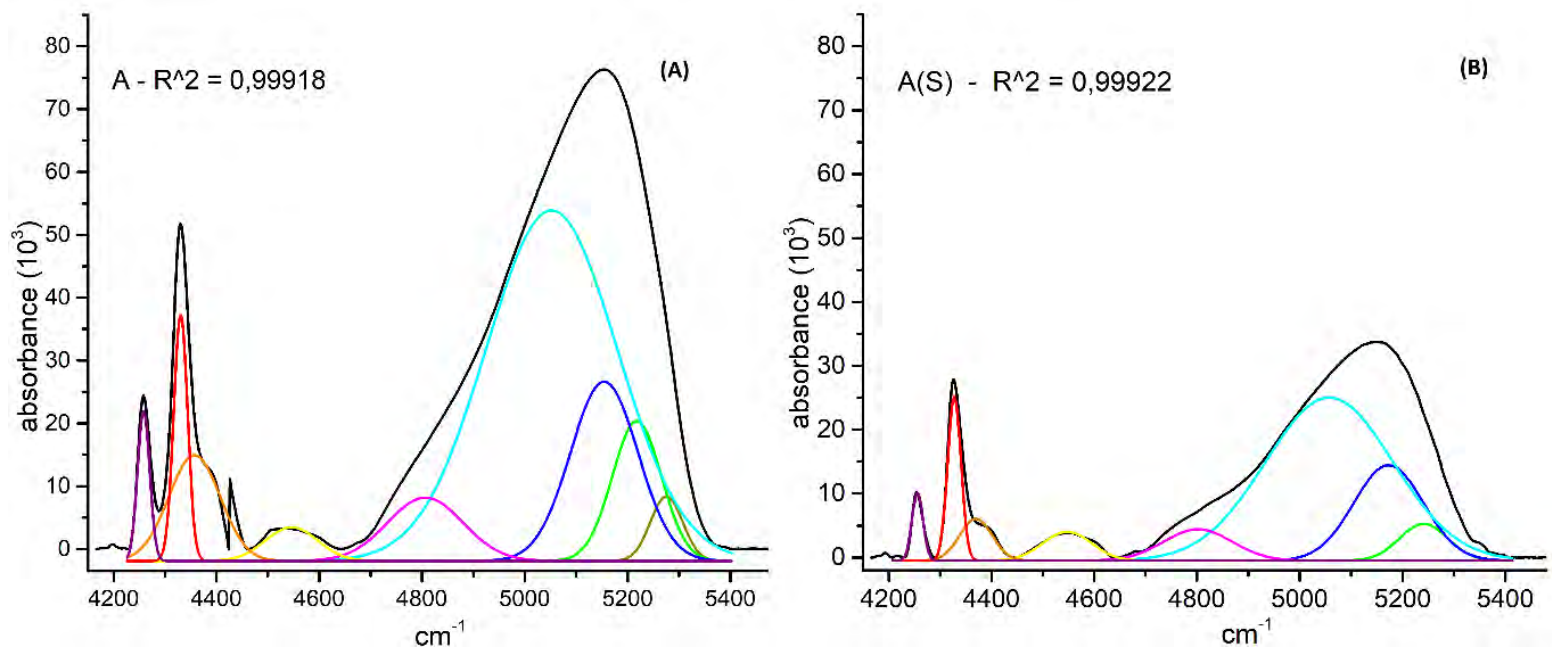
Figura 22 - Espectros de absorbância de NIR, na região entre 4200 a $5500 \mathrm{~cm}^{-1}$, das superfícies dos corpos porosos de alumina-zircônia, após tratamento químico $(A)$ e com substituição iônica (B).
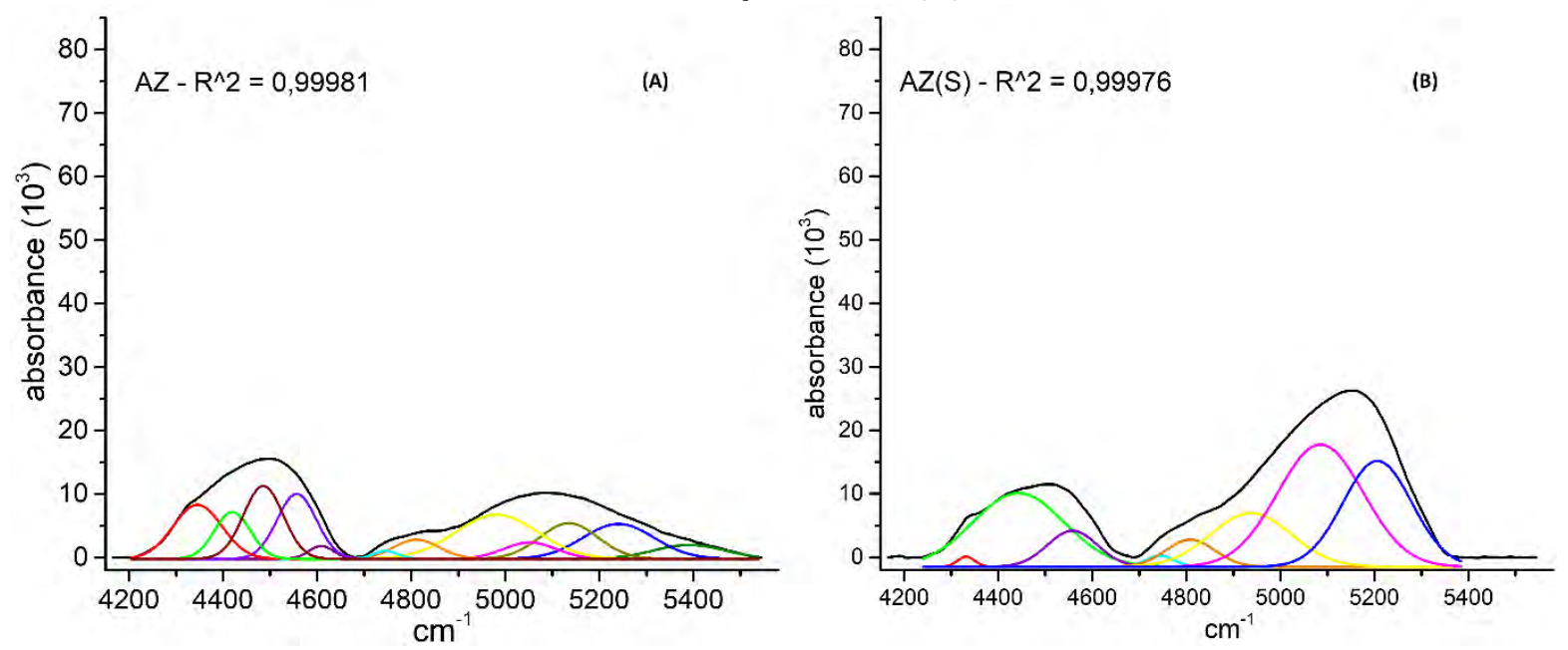

Para essa análise os corpos porosos foram secos para diminuir o excesso de umidade, que dificultaria a análise dos fosfatos de cálcio formados sobre as superfícies recobertas, porém, secagem em que os corpos porosos recobertos com fosfato de cálcio foram submetidos provavelmente eliminou a água livre de superfície, mas não a água adsorvida e estrutural.

Nesse intervalo selecionado, as informações encontradas são devido ao resultado da associação de vibrações de estiramento (stretching - $v$ ), angulares (bending - $\delta$ ) e da região de impressão digital (fingerprint) do infravermelho médio, enquanto, as bandas de combinação, largas e intensas, são resultantes da soma dos modos de estiramento e angulares (WORKMAN JR; WEYER, 2012).

No entanto, os espectros de NIR ainda apresentam bandas intensas de água adsorvida nas superfícies devido à sensibilidade da técnica para vibrações $\mathrm{OH}$. A presença da água, mesmos após a secagem, pode ser atribuída também à alta hidrofilicidade dos cristais de fosfato de cálcio formados nas superfícies dos nanocompósitos. A partir dos espectros de NIR de apatitas sintéticas, Kolmas e colaboradores (KOLMAS; MAREK; KOLODZIEJSKI, 2015) observaram o comportamento da água adsorvida nos cristais de fosfatos de cálcio e verificaram que poderia estar presente de maneiras distintas: (i) como água estrutural contida no volume interno da rede cristalina; (ii) como água adsorvida pelos cátions $\mathrm{Ca}^{+}$ou por ligações de hidrogênio nos grupos P-OH presentes nas superfícies do cristal; ou (iii) como água superficial livre. 
A Tabela 13 descreve as bandas de combinação (teóricas e experimentais) dos espectros de NIR das superfícies dos corpos porosos de $A$ e $A Z$ recobertos e com substituição iônica pelo $\mathrm{Sr}^{2+}$, deconvolução referentes às bandas de combinação dos espectros de NIR das superfícies dos corpos porosos de $A$ e $A Z$ e Tabela 14 descreve as bandas de combinação (teóricas e experimentais) dos espectros de NIR das superfícies dos corpos porosos de $A$ e $A Z$ recobertos e com substituição iônica pelo $\mathrm{Sr}^{2+}$, deconvolução referentes às bandas de combinação dos espectros de NIR das superfícies dos corpos porosos de $A$ e $A Z$ e os grupos de $\mathrm{PO}_{4}^{-3}$ formados na superfície dos recobrimentos tratados biomimeticamente.

Tabela 13 - Área percentual sob as curvas de deconvolução referentes às bandas de combinação dos espectros de NIR das superfícies dos corpos porosos de $A$ e $A Z$.

\begin{tabular}{|c|c|c|c|c|c|}
\hline \multirow{2}{*}{$\begin{array}{l}\text { Atribuições de combinação de bandas } \\
\text { teóricas calculadas }\left(\mathrm{cm}^{-1}\right)\end{array}$} & \multicolumn{5}{|c|}{$\begin{array}{c}\text { Bandas de } \mathrm{Al}_{2} \mathrm{O}_{3} \text { e nanocompósitos de } \mathrm{Al}_{2} \mathrm{O}_{3}-\mathrm{ZrO}_{2} \text { recobertos } \\
\text { biomimeticamente ( } \mathrm{SBF} 5 \mathrm{x} \text { ) }\end{array}$} \\
\hline & Corpo Poroso & $A$ & $A(S r)$ & $A Z$ & $A Z(S)$ \\
\hline \multirow{2}{*}{$v_{a}+v_{c}=3484.3+839.8=4324.1$} & Posição & 4330 & 4328 & - & - \\
\hline & Área (\%) & 4,07 & 5,88 & - & - \\
\hline \multirow[b]{2}{*}{$2 \delta_{a}+\delta_{b}=2 \times 1395.9+1643.7=4435.5$} & Posição & - & - & 4420 & 4435 \\
\hline & Área (\%) & - & - & 7,92 & 26,74 \\
\hline \multirow[b]{2}{*}{$3 \delta_{a}+v_{b}=3 \times 1395.9+537.4=4725.1$} & Posição & - & - & 4745 & 4744 \\
\hline & Área (\%) & - & - & 0,92 & 1,25 \\
\hline \multirow{2}{*}{$v_{a}+\delta_{a}=3484.3+1395.9=4880.2$} & Posição & 4807 & 4802 & 4811 & 4809 \\
\hline & Área (\%) & 5,68 & 5,80 & 4,15 & 5,31 \\
\hline \multirow{2}{*}{$3 \delta_{b}=3 \times 1643.7=4931.1$} & Posição & - & - & 4982 & 4938 \\
\hline & Área (\%) & - & - & 17,15 & 17,24 \\
\hline \multirow{2}{*}{$v_{a}+\delta_{b}=3484.3+1643.7=5128.0$} & Posição & $5052 / 5154$ & $5058 / 5172$ & $5135 / 5052$ & 5085 \\
\hline & Área (\%) & $54,55 / 14,36$ & $56,23 / 17,70$ & $9,79 / 4,07$ & 41,61 \\
\hline \multirow{2}{*}{$\begin{array}{c}v_{a}+v_{b}+\delta_{b}=3484.3+537.4+1643.7 \\
=5665.4\end{array}$} & Posição & $5218 / 5276$ & 5241 & $5392 / 5241$ & - \\
\hline & Área (\%) & $8,16 / 2,46$ & 4,96 & $4,69 / 11,76$ & - \\
\hline
\end{tabular}

* $v_{\mathrm{a}}$ : vibração de estiramento de $\mathrm{OH}$ de água adsorvido fisicamente em $\mathrm{Al}^{3+}$ ou $\mathrm{Zr}^{4+}\left(3484.3 \mathrm{~cm}^{-1}\right) ; v_{\mathrm{b}}$ : viração de estiramento de $\mathrm{Zr}-\mathrm{O}\left(537.4 \mathrm{~cm}^{-1}\right)$; $v_{c}$ : vibração de estiramento de Al-O ( 839.8 cm-1); $\delta_{\mathrm{a}}$ : vibração angular de AlO-H e de Zr-O-H ( 1395.9 cm cm $^{-1}$; $\delta_{\mathrm{b}}$ : vibração angular de Al-O-H e de Zr-O-H $\left(\sim 1643.7\right.$ cm$\left.^{-1}\right)$ (SARKAR et al., 2007) 
Tabela 14 - Área percentual sob as curvas de deconvolução referentes às bandas de combinação dos espectros de NIR das superfícies dos corpos porosos de $\mathrm{Al}_{2} \mathrm{O}$ e $\mathrm{ZrO}_{2}-\mathrm{Al}_{2} \mathrm{O}_{3}$ tratados biomimeticamente e os grupos de $\mathrm{PO}_{4}{ }^{-3}$ formados na superfície dos recobrimentos.

\begin{tabular}{|c|c|c|c|c|c|}
\hline \multirow{2}{*}{$\begin{array}{l}\text { Atribuições de combinação de bandas } \\
\text { teóricas calculadas }\left(\mathrm{cm}^{-1}\right)\end{array}$} & \multicolumn{5}{|c|}{$\begin{array}{c}\text { Bandas de } \mathrm{Al}_{2} \mathrm{O}_{3} \text { e nanocompósitos } \mathrm{Al}_{2} \mathrm{O}_{3}-\mathrm{ZrO}_{2} \text { recobertos } \\
\text { biomimeticamente ( } \mathrm{SBF} 5 \mathrm{x} \text { ) }\end{array}$} \\
\hline & Corpo Poroso & $A$ & $A(S)$ & $A Z$ & $A Z(S)$ \\
\hline \multirow{2}{*}{$\begin{array}{c}* \star 2 v_{3} a+2 \delta_{1} b+2 \delta_{2 b}=2 \times 1087+2 x \\
462+2 \times 574=4246\end{array}$} & Posição & 4258 & 4256 & - & - \\
\hline & Área (\%) & 2,15 & 2,01 & - & - \\
\hline \multirow{2}{*}{$\begin{aligned}{ }^{* \star} 3 v_{3 b}+2 \delta_{2 a}= & 3 \times 1046+2 \times 602= \\
& 4342\end{aligned}$} & Posição & 4357 & - & 4346 & 4332 \\
\hline & Área (\%) & 6,48 & - & 12,43 & 0,69 \\
\hline \multirow{2}{*}{$\begin{aligned}{ }^{\star *} 3 v_{s} 2+2 \delta 1 b+\delta 2 b & =3 \times 962+2 x \\
462+574 & =4384\end{aligned}$} & Posição & & 4370 & - & - \\
\hline & Área (\%) & & 3,65 & - & - \\
\hline \multirow{2}{*}{$\begin{aligned} * * 3 v 3 c+3 \delta 1 b= & 3 \times 1032+3 \times 462= \\
& 4482\end{aligned}$} & Posição & & - & 4486 & - \\
\hline & Área (\%) & & - & 13,60 & - \\
\hline \multirow{2}{*}{${ }^{* *} v_{1}+v_{\mathrm{s} 2}=3572+960=4534$} & Posição & 4546 & 4548 & 4557 & 4558 \\
\hline & Área (\%) & 2,09 & 3,77 & 11,98 & 7,16 \\
\hline \multirow{2}{*}{${ }^{* *} v_{1}+v_{3 c}=3572+1032=4604$} & Posição & - & - & 4609 & - \\
\hline & Área (\%) & - & - & 1,53 & - \\
\hline
\end{tabular}

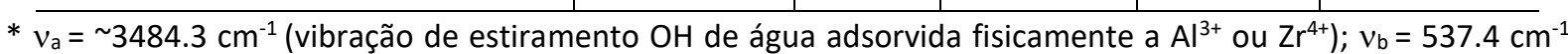
(vibração de estiramento $\mathrm{Zr}-0$ ); $v_{\mathrm{c}}=\sim 839.8 \mathrm{~cm}^{-1}$ (vibração de estiramento Al-O); $\delta_{\mathrm{a}}=\sim 1643,7$ e $\delta \mathrm{b}=\sim 1395,9 \mathrm{~cm}$ ${ }^{1}$ (vibração angular de $\mathrm{Zr}-\mathrm{OH}$ e Al-OH) (SARKAR et al., 2007).

** $v_{1}=\sim 3572$ (vibração de estiramento P-OH); $v_{\mathrm{s} 2}=\sim 960 \mathrm{~cm}^{-1}$ (vibração de estiramento simétrico P-O); $v_{3 \mathrm{a}}=$ $\sim 1087 \mathrm{~cm}^{-1}, v_{3 b}=\sim 1046 \mathrm{~cm}^{-1} \mathrm{e} v_{3 c}=\sim 1032 \mathrm{~cm}^{-1}$ (vibração de estiramento assimétrico P-O); $\delta_{1 \mathrm{a}}=\sim 472 \mathrm{~cm}^{-1} \mathrm{e} \delta_{1 \mathrm{~b}}$ $=462 \mathrm{~cm}^{-1}$ (vibração angular O-P-O (doubly degenerated bending mode)); $\delta_{2 \mathrm{a}}=\sim 602 \mathrm{~cm}^{-1}, \delta_{2 \mathrm{~b}}=\sim 574 \mathrm{~cm}^{-1} \mathrm{e} \delta_{2 \mathrm{c}}$ $=\sim 561 \mathrm{~cm}^{-1}$ (vibração angular de O-P-O (triply degenerated beding mode)) (KOUTSOPOULOS, 2002; REDDY et al., 2014; SURESHBABU; KOMATH; VARMA, 2012).

Para atribuição das bandas de overtones e de combinação dos fosfatos de cálcio formados sobre as superfícies dos corpos porosos, utilizou-se bandas vibracionais de estiramento e angulares, no estado fundamental, na região do infravermelho médio, do grupo fosfato. Os modos vibracionais de estiramento considerados foram: (i) estiramento de $\mathrm{OH}$ do grupo funcional P-OH em $\sim 3572 \mathrm{~cm}^{-1}\left(v_{1}\right)$; (ii) estiramento simétrico não degenerado do grupo $\mathrm{P}-\mathrm{O}$ em $\sim 960 \mathrm{~cm}^{-1}\left(v_{\mathrm{s} 2}\right)$; (iii) estiramento assimétrico degenerado do grupo P-O em $\sim 1087 \mathrm{~cm}^{-}$ ${ }^{1}\left(v_{3 a}\right)$, em $\sim 1046 \mathrm{~cm}^{-1}\left(v_{3 b}\right)$ e em $\sim 1032 \mathrm{~cm}^{-1}\left(v_{3 c}\right)$. Já os modos vibracionais angulares considerados foram: (iv) vibração angular duplamente degenerada do grupo O-P-O em 472 $\mathrm{cm}^{-1}\left(\delta_{1 \mathrm{a}}\right)$, em $462 \mathrm{~cm}^{-1}\left(\delta_{1 \mathrm{~b}}\right)$, em $\sim 602 \mathrm{~cm}^{-1}\left(\delta_{2 \mathrm{a}}\right)$ e em $\sim 574 \mathrm{~cm}^{-1}\left(\delta_{2 \mathrm{~b}}\right)$; $(v)$ vibração angular triplamente degenerada do grupo O-P-O em $\sim 561 \mathrm{~cm}^{-1}\left(\delta_{2 c}\right)$ (KOLMAS et al., 2015; REDDY et al., 2014). 
$\mathrm{O}$ íon $\mathrm{CO}_{3}{ }^{-}$(carbonato) é encontrado na região NIR em duas fortes bandas próximas a 3920 e $4255 \mathrm{~cm}^{-1}$. O pico $4255 \mathrm{~cm}^{-1}$ é atribuído como o segundo overtone do estiramento assimétrico forte $\left(3 \mathrm{v}_{3}\right)$.

Os espectros das regiões $4500-5800$ e $6200-8000 \mathrm{~cm}^{-1}$, constituem a combinação dos primeiros e segundas bandas de overtones respectivamente. Para a região entre 4300-5500 $\mathrm{cm}^{-1}$ são encontrados os grupos de fosfatos $\mathrm{PO}_{4}{ }^{3-}$, sendo, o $\beta$-TCP encontrado na banda de $4500 \mathrm{~cm}^{-1}$ (KOLMAS et al., 2015). A região de 4000 a $4670 \mathrm{~cm}^{-1}$ indica um aumento no modo vibracional do grupo $\mathrm{OH}$ estrutural do fosfato de cálcio, como exemplo de estrutura formada têm-se a HA (ISHIKAWA; WAKAMURA; KONDO, 1989). A banda de absorção da região 4342 $\mathrm{cm}^{-1}$ é atribuída ao modo de estiramento assimétrico triplamente degenerado da ligação P-O do grupo $\mathrm{PO}_{4}{ }^{3-}$. Enquanto as bandas de absorção observadas na região entre 4133 e $4604 \mathrm{~cm}^{-}$ ${ }^{1}$ são atribuídas ao modo de estiramento assimétrico triplamente degenerado da ligação do grupo $\mathrm{PO}_{4}{ }^{3-}$ e da fase $\alpha$-TCP. As vibrações observadas na região entre $4534 \mathrm{~cm}^{-1}$ são também atribuídas ao grupo $\mathrm{HPO}_{4}{ }^{2-}$ da $\mathrm{HA}$ não estequiométrica e modo de estiramento da fase $\beta$-TCP. A banda de absorção e $4604 \mathrm{~cm}^{-1}$ é atribuída ao modo de estiramento assimétrico do grupo $\mathrm{PO}_{4}{ }^{3-}$. Finalmente, as bandas de absorção observadas nas regiões entre 4272 e $4384 \mathrm{~cm}^{-1}$ são atribuídas ao modo de estiramento do grupo $\mathrm{PO}_{4}{ }^{3-}$ (ISHIKAWA et al., 1989; KOLMAS et al., 2015). As bandas de combinação de baixa frequência, encontradas em pontos abaixo de 4800 $\mathrm{cm}^{-1}$, originam-se dos grupos P-OH de superfície, como as bandas 4690, 4673, 4657 e 4615 $\mathrm{cm}^{-1}$ encontradas em diversos trabalhos. A hidroxiapatita (HA) é um exemplo de fase de fosfato de cálcio que contenham OH na sua estrutura (ISHIKAWA et al., 1989).

A vibração de estiramento de Al-OH é encontrada no pico $3484,3 \mathrm{~cm}^{-1}$, estiramento das ligações cristalinas Al-O e Zr-O em bandas de absorção em frequências mais baixas 839,8 $\mathrm{cm}^{-1}$ e $537.4 \mathrm{~cm}^{-1}$ (SARKAR et al., 2007). Em $3656 \mathrm{~cm}^{-1}$ ocorre o desaparecimento desse pico que é devido à vibração de estiramento de $\mathrm{OH}^{-}$no $\mathrm{Al}^{+3}$, surgindo uma vibração de estiramento de $\mathrm{OH}^{-}$no pico $3552 \mathrm{~cm}^{-1}$ devido a introdução da $\mathrm{ZrO}_{2}$ na matriz cerâmica (SARKAR et al., 2007).

A Figura 23 relaciona a percentagem de formação de fosfatos identificados nos espectros de absorção de NIR e calculados a partir da Tabela 14. Pode-se observar que ocorreu uma maior formação de fosfatos nos corpos porosos AZ. Nos corpos porosos de AZ(S) ocorreu uma diminuição na formação de fosfatos, que pode ser atribuído à substituição do $\mathrm{Ca}^{2+}$ pelo $\mathrm{Sr}^{2+}$. 
Figura 23 - Percentagem de fosfatos formados identificados através dos espectros de absorção de NIR.

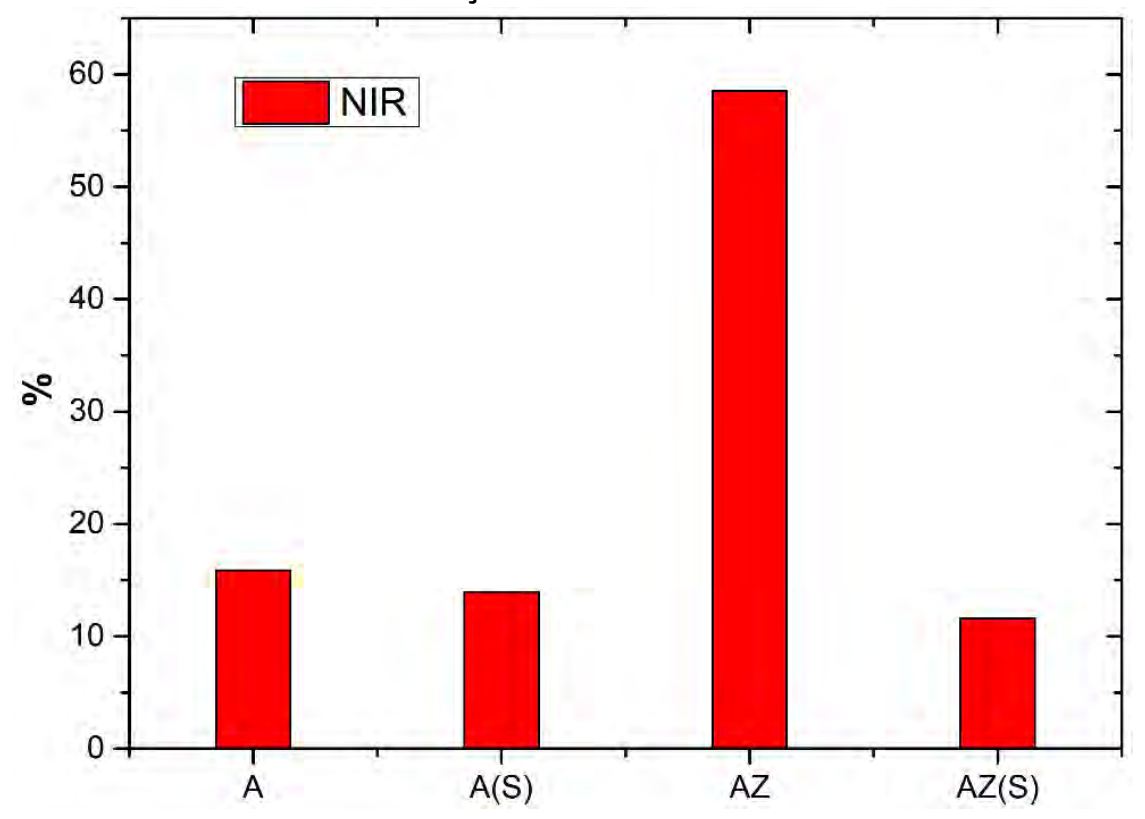

Os fosfatos de cálcio substituídos ionicamente pelo estrôncio desloca as linhas de fosfato e $\mathrm{OH}$ - entre termos finais de Cálcio puro e hidroxiapatita. As linhas de infravermelho são deslocadas globalmente para números de onda inferiores quando um cátion de raio maior e pesado substitui um menor e mais leve. Este fenômeno está frequentemente relacionado com o volume da célula unitária e, indiretamente, com a razão de substituição (ANTONIAC, 2016). O número de linhas, contudo, permanece consistente para todos os espectros da série com o de uma estequiometria de cálcio ou fosfato de estrôncio (ANTONIAC, 2016).

Como esperado, impurezas como o $\mathrm{Sr}^{2+}$ na rede dos fosfatos de cálcio introduzem tensões significativas na estrutura cristalina, tornando-as menos estáveis e mais reativas. Isso ocorre devido a semelhança no raio atômico e eletronegatividade do $\mathrm{Ca}^{2+} \mathrm{e} \mathrm{Sr}^{2+}$ (ANTONIAC, 2016).

Para uma estrutura de célula unitária $\mathrm{CFC}$, como considerado o $\mathrm{Ca}^{2+}$ e $\mathrm{Sr}^{2+}$ pode-se calcular o volume dos átomos em uma célula unitária, onde, considera-se o raio atômico 194 pm para o $\mathrm{Ca}^{2+}$ e 219 pm para o $\mathrm{Sr}^{2+}$. Esse volume é calculado de acordo com a Equação 5 (CALLISTER; RETHWISCH, 2011).

$$
V_{e}=(4) \frac{4}{3} \pi R^{3}
$$

\section{Equação 5}


Onde,

$V_{e}$ - Volume dos átomos em uma célula unitária

$R$ - Raio atômico

De acordo com os cálculos produzidos, foi encontrado um volume da célula unitária do $\mathrm{Ca}^{2+}$ de $1,223 \cdot 10^{-28} \mathrm{~m}$, enquanto para o $\mathrm{Sr}^{2+}$ um volume de $1,759 \cdot 10^{-28} \mathrm{~m}$, ou seja, a célula unitária do $\mathrm{Sr}^{2+}$ é aproximadamente $30 \%$ maior que a célula unitária do $\mathrm{Ca}^{2+}$. Nesse sentido, a substituição iônica não deve ocorrer em sua totalidade na rede cristalina, ocorrendo a necessidade de cada célula unitária de $\mathrm{Sr}^{2+}$ substituir pelo menos duas células unitárias de $\mathrm{Ca}^{2+}$.

O deslocamento de linhas simples como $\mathrm{O} I \mathrm{R}$ de $\mathrm{PO}_{4}$ pode ser linearmente correlacionado com a taxa de substituição, mesmo se a distribuição de cátions entre os dois locais catiônicos da estrutura não for homogênea nesse tipo de substituição (AINA et al., 2012; ANTONIAC, 2016).

O alargamento da linha é geralmente observado para o fosfato de cálcio substituído. Está relacionado com a irregularidade da matriz atômica, muitas vezes referida como estirpe de rede, embora várias causas possam estar envolvidas. À medida que a razão de substituição aumenta, a desordem aumenta (ANTONIAC, 2016).

A Figura 24 apresenta os Difratogramas de raios-X, deconvoluídos, da superfície dos corpos porosos de $\mathrm{Al}_{2} \mathrm{O}_{3}(\mathrm{~A})$ e $\mathrm{Al}_{2} \mathrm{O}_{3}-\mathrm{ZrO}_{2}(\mathrm{AZ})$ recobertos com fosfatos de cálcio após 14 de incubação em SBF (5x), apresentam respectivamente, os difratogramas de raios-X e nos intervalos $27^{\circ}$ a $34^{\circ}$ das superfícies das cerâmicas porosas de $A$ e $A Z$ e recobertas com SBF $5 x$ após tempo de incubação de 14 dias.

O ajuste matemático (fitting) dos difratogramas foi realizado no intuito de se quantificar as fases de fosfatos de cálcio formadas. Para tal, foi utilizado o método de deconvolução com função gaussiana, obtendo-se curvas com $\mathrm{R}^{\wedge} 2=0,99$. 
Figura 24 - Difratogramas de raios- $X$, deconvoluídos, das superfícies dos corpos porosos de $\mathrm{Al}_{2} \mathrm{O}_{3}(\mathrm{~A})$ e $\mathrm{Al}_{2} \mathrm{O}_{3}-\mathrm{ZrO}_{2}(\mathrm{AZ})$ recobertos com fosfatos de cálcio após 14 de incubação em SBF (5x).
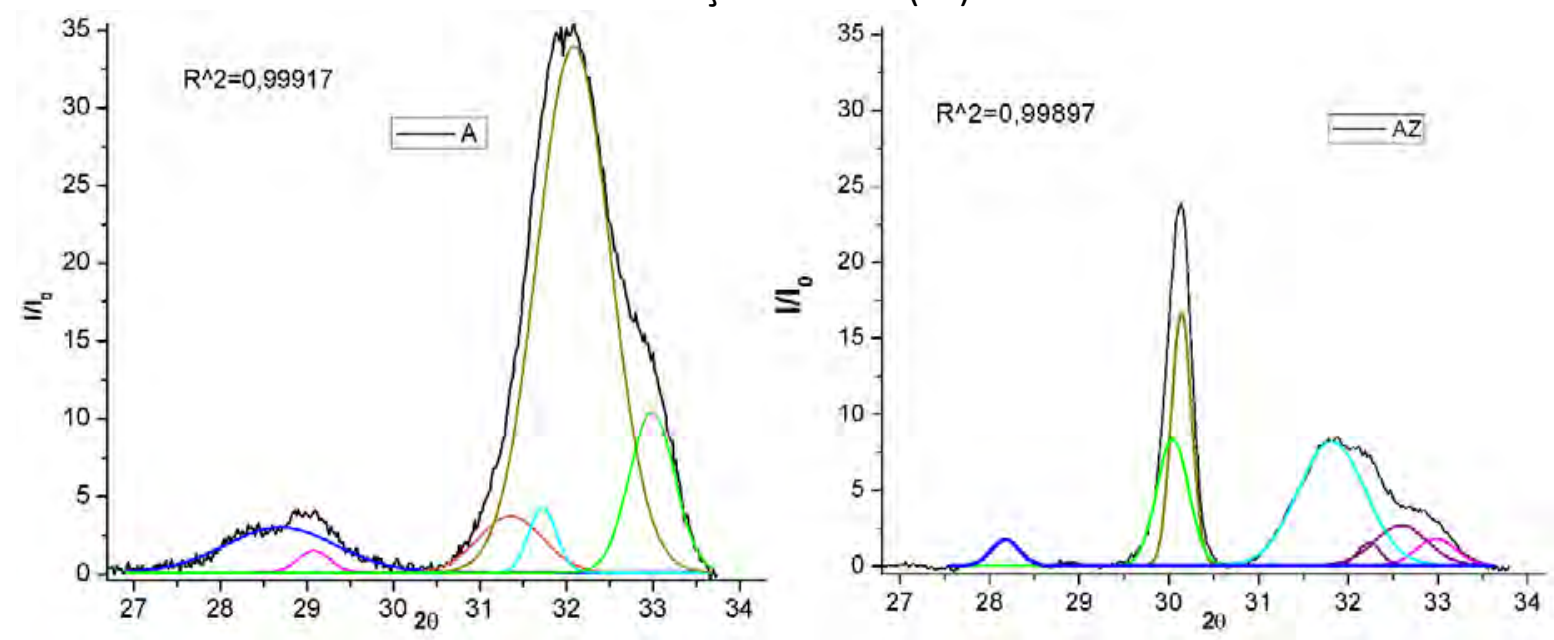

As Figura 25 e Figura 26 apresenta os Difratogramas de raios-X, deconvoluídos, da superfície dos corpos porosos de $\mathrm{Al}_{2} \mathrm{O}_{3}(\mathrm{~A}(\mathrm{~S}))$ e $\mathrm{Al}_{2} \mathrm{O}_{3}-\mathrm{ZrO}_{2}(\mathrm{AZ}(\mathrm{S}))$ recobertos com fosfatos de cálcio após 14 de incubação em SBF $(5 x)$ e substituídas ionicamente pelo estrôncio. Apresentam respectivamente, os difratogramas de raios- $X$ e nos intervalos $10^{\circ}$ a $24,5^{\circ}$ e $27^{\circ}$ a $34^{\circ}$.

Figura 25 - Difratograma de raios- $X$, deconvoluídos, da superfície dos corpos porosos de $A(S)$ recobertos com fosfatos de cálcio após 14 de incubação em SBF (5x) e substituídas ionicamente pelo $\mathrm{Sr}^{2+}$ em dois intervalos encontrados.
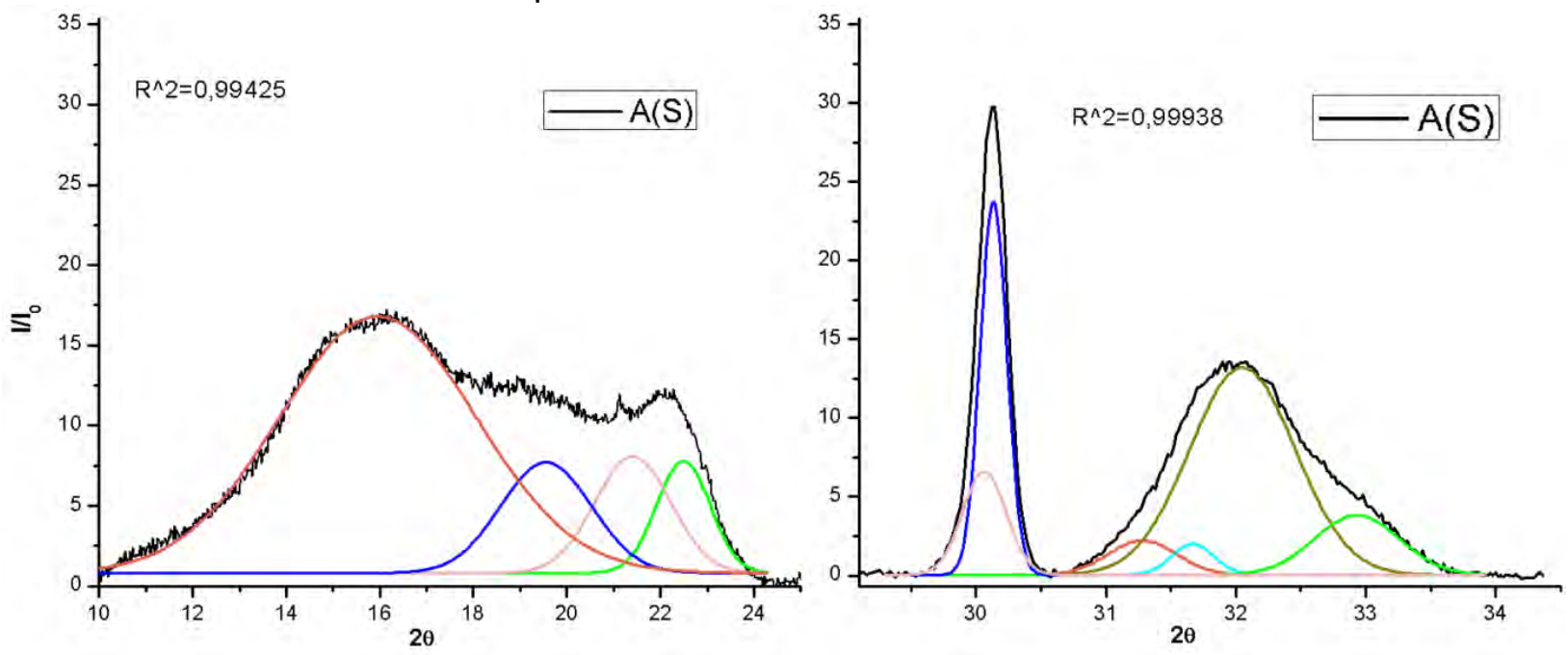
Figura 26 - Difratograma de raios- $X$, deconvoluídos, da superfície dos corpos porosos de $A Z$ com tratamento superficial, recobertos com fosfatos de cálcio após 14 de incubação em SBF (5x) e substituídas ionicamente pelo $\mathrm{Sr}^{2+}$ em dois intervalos encontrados.
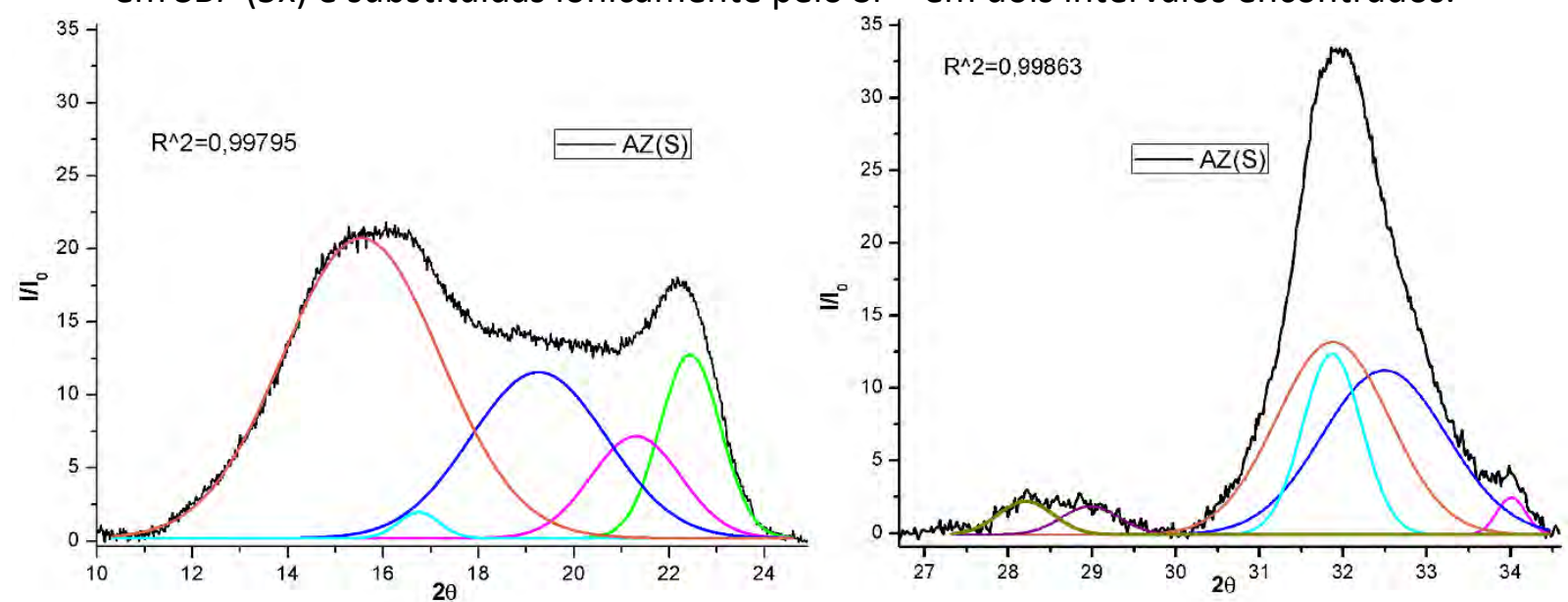

A Tabela 15 mostra a relação das fases encontradas para cada corpo poroso, a porcentagens das fases, bem como padrão característico (Índices de Miller (hk/)) obtidos através dos difratogramas de Raio-X.

Tabela 15 - Relação das fases encontradas para cada corpo poroso, suas referências cristalográficas e a porcentagem encontradas através da técnica de difratometria de Raio-X.

\begin{tabular}{|c|c|c|c|c|}
\hline $\begin{array}{l}\text { Corpo } \\
\text { Poroso }\end{array}$ & $2 \theta$ & $\begin{array}{c}\text { Referências } \\
\text { Cristalográficas }\end{array}$ & $\begin{array}{c}\text { Percentagem } \\
\text { (\%) }\end{array}$ & Fase encontrada \\
\hline \multirow{6}{*}{ A } & $28,7^{\circ}$ & $(214) /(-211)$ & 8,75 & $\beta-\mathrm{TCP} / \mathrm{TTCP}$ \\
\hline & $29,08^{\circ}$ & (040) & 1,2 & TTCP \\
\hline & $31,35^{\circ}$ & (02 10) & 6,34 & $\beta-\mathrm{TCP}$ \\
\hline & $31,72^{\circ}$ & $(221) /(511)$ & 3,14 & TTCP $/ \alpha-\mathrm{TCP}$ \\
\hline & $32,08^{\circ}$ & $(121) /(-212)$ & 67,8 & Hidroxiapatita/ TTCP \\
\hline & $32,98^{\circ}$ & (121) & 12,76 & Hidroxiapatita \\
\hline \multirow{10}{*}{$\mathrm{A}(\mathrm{Sr})$} & $15,96^{\circ}$ & (211) & 66,96 & Fosfato de Estrôncio \\
\hline & $19,56^{\circ}$ & $(202) /(111)$ & 13,32 & Fosfato de Estrôncio/Nitrato de Estrôncio \\
\hline & $21,41^{\circ}$ & (022) & 11,75 & Fosfato de Estrôncio \\
\hline & $22,49^{\circ}$ & $(122)$ & 7,97 & Fosfato de Estrôncio \\
\hline & $30,13^{\circ}$ & $(123) /(170)$ & 22,12 & Fosfato de Estrôncio/ $\alpha$-TCP \\
\hline & $30,06^{\circ}$ & (040) & 10 & TTCP \\
\hline & $31,28^{\circ}$ & $(223) /(0210)$ & 5,17 & Fosfato de Estrôncio/ $\beta$-TCP \\
\hline & $31,67^{\circ}$ & $(221) /(511)$ & 2,9 & $\mathrm{TTCP} / \alpha-\mathrm{TCP}$ \\
\hline & $32,05^{\circ}$ & $(121) /(422)$ & 48,62 & Hidroxiapatita/Fosfato de Estrôncio \\
\hline & $32,93^{\circ}$ & $(121) /(521)$ & 11,19 & Hidroxiapatita/Fosfato de Estrôncio \\
\hline \multirow{5}{*}{$\mathbf{A Z}$} & $28,17^{\circ}$ & $(510) /(-211)$ & 4,39 & $\alpha-\mathrm{TCP} / \mathrm{TTCP}$ \\
\hline & $30,04^{\circ}$ & (032) & 24,45 & TTCP \\
\hline & $30,14^{\circ}$ & (040) & 30,75 & TTCP \\
\hline & $31,81^{\circ}$ & $(221) /(511)$ & 17,73 & TTCP $/ \alpha-\mathrm{TCP}$ \\
\hline & $32,23^{\circ}$ & (121) & 3,15 & Hidroxiapatita \\
\hline
\end{tabular}




\begin{tabular}{|c|c|c|c|c|}
\hline & $32,58^{\circ}$ & $(121) /(-212)$ & 12,96 & Hidroxiapatita / TTCP \\
\hline & $32,97^{\circ}$ & (121) & 6,54 & Hidroxiapatita \\
\hline \multirow{10}{*}{$A Z(S r)$} & $15,54^{\circ}$ & (211) & 51,78 & Fosfato de Estrôncio \\
\hline & $16,75^{\circ}$ & $(110) /(211)$ & 1,18 & $\beta$-TCP/ Fosfato de Estrôncio \\
\hline & $19,26^{\circ}$ & $(202) /(111)$ & 24,75 & Fosfato de Estrôncio/Nitrato de Estrôncio \\
\hline & $21,30^{\circ}$ & (022) & 10,06 & Fosfato de Estrôncio \\
\hline & $22,43^{\circ}$ & (122) & 12,23 & Fosfato de Estrôncio \\
\hline & $28,21^{\circ}$ & $(211) /(214)$ & 3,21 & $\mathrm{TTCP} / \beta-\mathrm{TCP}$ \\
\hline & $28,94^{\circ}$ & (040) & 2,85 & Fosfato de Estrôncio \\
\hline & $31,94^{\circ}$ & $(121) /(510)$ & 56,42 & Hidroxiapatita / $\alpha-\mathrm{TCP}$ \\
\hline & $32,90^{\circ}$ & (212) & 35,64 & TTCP \\
\hline & $33,00^{\circ}$ & $(220) /(323)$ & 1,87 & $\beta$-TCP/ Fosfato de Estrôncio \\
\hline
\end{tabular}

Após o recobrimento biomimético, os corpos porosos de $A$ e $A Z$ foram analisados por DRX, a fim de caracterizar as fases de fosfatos de cálcio formadas sobre a superfície dos substratos cerâmicos, sem tratamento com Nitrato de Estrôncio $\left(\mathrm{Sr}\left(\mathrm{NO}_{3}\right)_{2}\right)$ e tratados superficialmente com tempo de incubação de $48 \mathrm{~h}$.

A partir da deconvolução das curvas, observou-se a formação de quatro fases distintas do fosfato de cálcio sobre as superfícies do nanocompósito: fosfato $\alpha$ tricálcico ( $\alpha$-TCP), fosfato $\beta$ tricálcico ( $\beta$-TCP), hidroxiapatita (HA) e Fosfato tetracálcico (TTCP)

As curvas deconvoluídas do difratograma de raio-X (DRX) mostraram a formação de fases distintas de fosfatos de cálcio sobre a superfície das cerâmicas porosas de $A$ e $A Z$ recobertas com SBF 5x e tempo de incubação de 14 dias e substituídas ou não, ionicamente pelo estrôncio. Assim foi possível distinguir as fases de $\beta$-TCP nos planos (2 14 ), (0 2 10), dos corpos porosos de $A$ com e sem incorporação do $\mathrm{Sr}^{2+}$. Nas cerâmicas porosas de $A Z$, também ocorreu a formação dessa mesma fase ( $\beta$-TCP), porém, com uma porcentagem maior, que foi encontrada no plano (0 20$)$.

Pôde-se observar que ocorreu uma diminuição de 9,925 \% na formação da fase $\beta$-TCP das cerâmicas porosas de $A$ para as $A(S)$. Isso se deve à formação de outras fases, como o fosfato de estrôncio, com a substituição do $\mathrm{Sr}^{2+}$. O mesmo ocorreu para as cerâmicas porosas de $A Z$ que diminuiu em $31,74 \%$ a formação da fase $\beta$-TCP quando adicionado o $\mathrm{Sr}^{2+}$ na rede cristalina. É importante ressaltar que as fases HA e $\beta$-TCP são consideradas como potenciais substitutos ósseos devido às suas propriedades de dissolução (HA não reabsorvível e $\beta$-TCP reabsorvível), rápida formação óssea e comportamento semelhante ao da fase inorgânica do osso (AINA et al., 2012; DOS SANTOS et al., 2017). 
Para a fase formada de $\alpha$-TCP nos planos $\left(\begin{array}{lll}5 & 1 & 1\end{array}\right)$ das cerâmicas porosas de $A$ ocorreu uma diminuição de 0,24 \%, enquanto, nas cerâmicas de $A Z$ ao adicionar o $\mathrm{Sr}^{2+}$ na rede cristalina, aumentou em 53,18 \% a formação dessa fase no plano (5 1 0). Na rede cristalina não se pode distinguir entre a formação da fase $\alpha$-TCP e TTCP.

Nos corpos porosos de A, ocorreu uma diminuição na porcentagem de formação da fase de Hidroxiapatita (HA) de $20,753 \%$ no plano $\left(\begin{array}{lll}1 & 2 & 1\end{array}\right)$ para os corpos porosos de A(S). Na rede cristalina não se pode distinguir entre a formação da fase de fosfato de estrôncio.

Em todos os corpos porosos a fase que ocorreu maior formação em diversos planos cristalográficos foi a TTCP, porém, não se pôde distinguir em alguns casos. Nas cerâmicas de A de formou um total de 80,89\% das fases de TTCP nos planos $(-211) /\left(\begin{array}{ll}0 & 4\end{array}\right) /(221) /(-212)$. Ao fazer a substituição iônica com o $\mathrm{Sr}^{2+}$ ocorreu uma diminuição drástica na porcentagem e nos planos cristalográficos formadas pelo TTCP. Forma-se um total de $12,9 \%$ da fase nos planos (0 40$)$ e (2 2 1).

Para os corpos porosos de cerâmicas porosas de AZ novamente mostrou que ocorreu maior formação em diversos planos cristalográficos foi a TTCP, porém, a mesma fase encontrada aumenta quando ocorre a substituição iônica com o $\mathrm{Sr}^{2+}$, desaparecendo alguns planos cristalográficos. Isso se deve à formação de fases como o fosfato de estrôncio. Formouse um total de 49,34\% da fase de TTCP nos planos $\left(\begin{array}{lll}-2 & 1 & 1\end{array}\right) /\left(\begin{array}{lll}0 & 3\end{array}\right) /\left(\begin{array}{ll}0 & 4\end{array}\right)$ e $\left(\begin{array}{lll}-2 & 1 & 2\end{array}\right)$. Os mesmo não se pôde distinguir em alguns casos. Para os mesmos corpos porosos que sofreram a substituição iônica pelo $\mathrm{Sr}^{2+}(A Z(S))$, com um total de 38,84 \% da fase de TTCP nos planos (2 1 1) e ( $\left(\begin{array}{lll}2 & 1 & 2\end{array}\right)$.

Nos corpos porosos de $A$ e $A Z$ que sofreram substituição iônica pôde-se perceber uma grande formação da fase de fosfato de estrôncio num total de $87,1 \%$ para a $A$ e 4,73 \% para $A Z$, na segunda região analisada, porém, não se pôde distinguir em alguns casos as fases. Enquanto na primeira região analisada, nos corpos porosos de $A$ e $A Z$, foram encontrados fosfato de estrôncio em todos os planos cristalográficos.

É sugerido quando o $\mathrm{Sr}^{2+}$ é introduzido na rede, mudanças de fase da HA e do $\beta$-TCP e o efeito do cátion relacionado com a variação dos parâmetros celulares da estrutura (expansão ou contração) (AINA et al., 2012).

Nos corpos porosos de $A(S)$ e $A Z(S)$, foi confirmada a fase de Fosfato de Estrôncio também nos planos cristalográficos (l $\left.\begin{array}{lll}2 & 1 & 1\end{array}\right) /\left(\begin{array}{lll}2 & 0 & 2\end{array}\right) /\left(\begin{array}{lll}0 & 2\end{array}\right) /\left(\begin{array}{lll}1 & 2 & 2\end{array}\right)$ e $\left(\begin{array}{lll}0 & 4 & 0\end{array}\right)$ referentes aos 
principais picos de formação da fase como confirmada em diversos trabalhos (AINA et al., 2012; GUO et al., 2005; HANIFI et al., 2010; YANG; LEE; LUI, 2015). Essa fase confirma a substituição do $\mathrm{Ca}^{2+}$ pelo $\mathrm{Sr}^{2+}$ mesmo o raio atômico do íon de estrôncio sendo 219 pm enquanto o íon cálcio é 194 pm. O aumento da quantidade de substituição iônica de estrôncio na estrutura de fosfato de cálcio resulta em partículas de tamanho menor (HANIFI et al., 2010).

A Figura 27 representa a porcentagem de fases formadas de fosfato de cálcio obtidas através da técnica de DRX e retirada da Tabela 15.

Figura 27 - Gráfico representando a percentagem de fases formadas de fosfato de cálcio obtidas através da técnica de DRX.

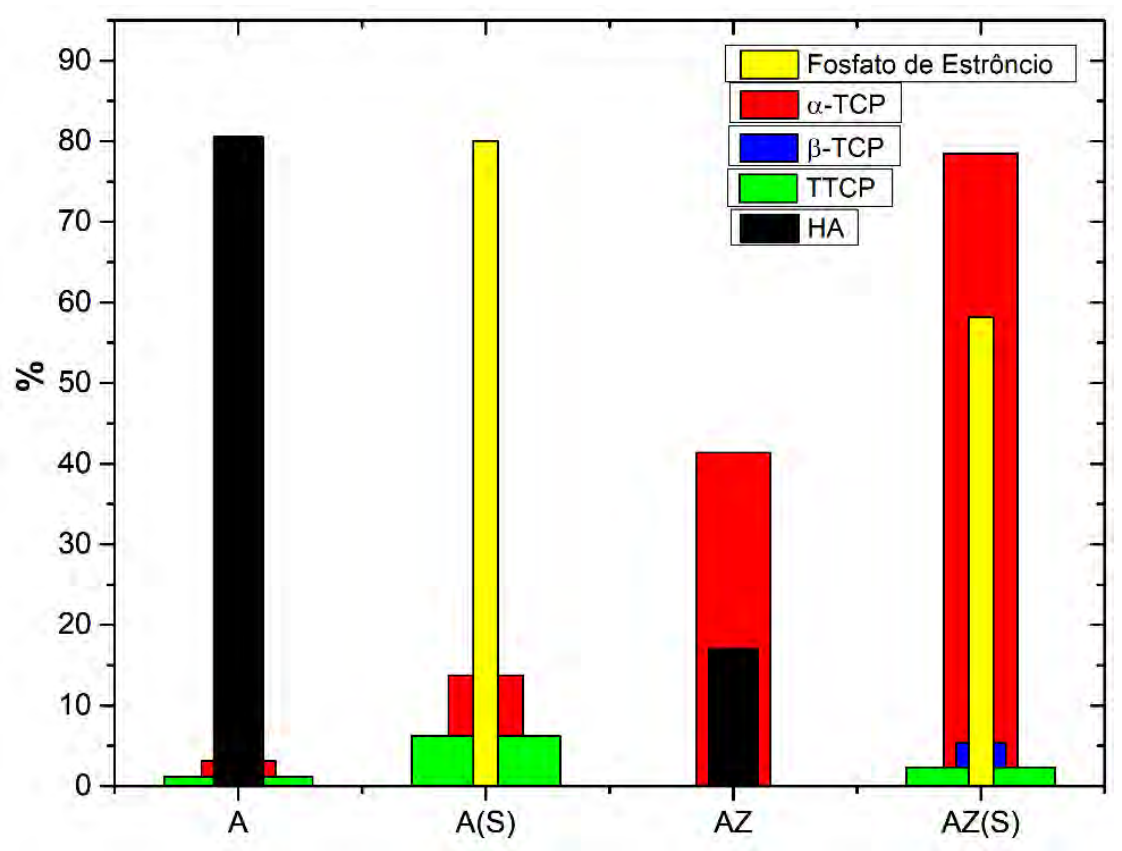

Para os corpos porosos de A ocorreu uma maior formação de HA, enquanto que para os corpos porosos de AZ a formação de HA diminuiu, mas aumento a formação de $\alpha$-TCP e TTCP. Quando ocorreu a substituição com $\mathrm{Sr}^{2+}$, percebeuse que nos corpos porosos de $\mathrm{A}(\mathrm{S})$ e AZ(S) ocorreu formação de fosfato de estrôncio, sendo em maior percentagem nos corpos porosos de $A(S)$. Porém, nos corpos porosos de $A Z(S)$ aumentou a formação de $\alpha$-TCP e diminuiu a formação de TTCP, além do aparecimento da fase $\beta$-TCP.

Para analisar a razão $\mathrm{Ca} / \mathrm{P}$ e $(\mathrm{Ca}+\mathrm{Sr}) / \mathrm{P}$ nos corpos porosos recobertos de $A, A Z, A(S)$ e $A Z(S)$, foi realizada análise de ICP-OES que são apresentadas na Tabela 16. 
Tabela 16 - Razão Ca/P e (Ca+Sr)/P dos corpos porosos recobertos, realizada por ICPOES.

\begin{tabular}{l|c|c}
\hline $\begin{array}{c}\text { Corpo } \\
\text { poroso }\end{array}$ & $\mathbf{C a} / \mathbf{P}$ & $\frac{\mathbf{C a}+\mathbf{S r}}{\mathbf{P}}$ \\
\hline $\boldsymbol{A}$ & 2,28 & - \\
$\boldsymbol{A Z}$ & 2,06 & - \\
$\boldsymbol{A}(\boldsymbol{S})$ & 2,05 & 2,46 \\
$\boldsymbol{A Z}(\boldsymbol{S})$ & 2,12 & 2,44 \\
\hline
\end{tabular}

Através dos resultados, pôde-se observar que nem todo o $\mathrm{Sr}^{2+}$ foi capaz de efetivamente entrar na estrutura de apatita (e suas fases de fosfato de cálcio) e que corpos porosos de $A Z$ tem maior aptidão em formar fases de fosfato de cálcio e fosfato de estrôncio que os corpos porosos de $A$. Valores elevados da $\mathrm{Ca} / \mathrm{P}$ encontrados, comparados à literatura (DOS SANTOS et al., 2017; LOBO, A. D. O., 2011), indicam a presença de fases de fosfatos de cálcio destacando-se a hidroxiapatita, TCP-fosfato tricálcio $(\alpha, \beta, x)$, fosfato de cálcio monohidratado e apatita insaturada.

As fases de fosfatos de cálcio formadas, são consideradas precipitados em meio básico, e sua razão $\mathrm{Ca} / \mathrm{P}$ ser próxima à 2,0, enquanto valores baixos são precipitados ácidos (AOKI, 1991). De acordo com essa razão, a possível fase formada de fosfato de cálcio é o Fosfato Tetracálcio (TTCP)-Ca ${ }_{4} \mathrm{P}_{2} \mathrm{O}_{9}$, também encontrada nas análises de DRX ( $\mathrm{AOKI}, 1991 ;$ LOBO, $\mathrm{A}$. O., 2011).

Como a razão $\mathrm{Ca} / \mathrm{P}$, no corpo poroso de $A Z$, foi próximo a 2,0 ocorreu o esperado para a substituição do $\mathrm{Sr}^{2+}$ na rede, pois, o valor da razão no corpo poroso de $A$ e $A Z$, são 2,4651 e 2,4383. Esses valores, maiores que dos corpos porosos de $A$ e $A Z$ são devido a formação de Fosfato de Estrôncio, pois, existem na rede o $\mathrm{Ca}^{2+} \mathrm{e} \mathrm{Sr}^{2+}$ nessa soma indicando a substituição dele na rede cristalina.

As Figuras 28, 29, 30 e 31 apresentam, respectivamente, as imagens obtidas por MEV da superfície dos corpos porosos cerâmicos de $A$ e $A Z$ recobertos após 7 e 14 dias de incubação em solução de SBF $5 x$. 
Figura 28 - Micrografias obtidas por MEV da superfície dos corpos porosos de Alumina recobertas com tempo de incubação de 7 dias. Imagem a) destacando a distribuição do recobrimento b) a distribuição dos cristais no poros e Imagem c) a formação homogênea dos cristais.
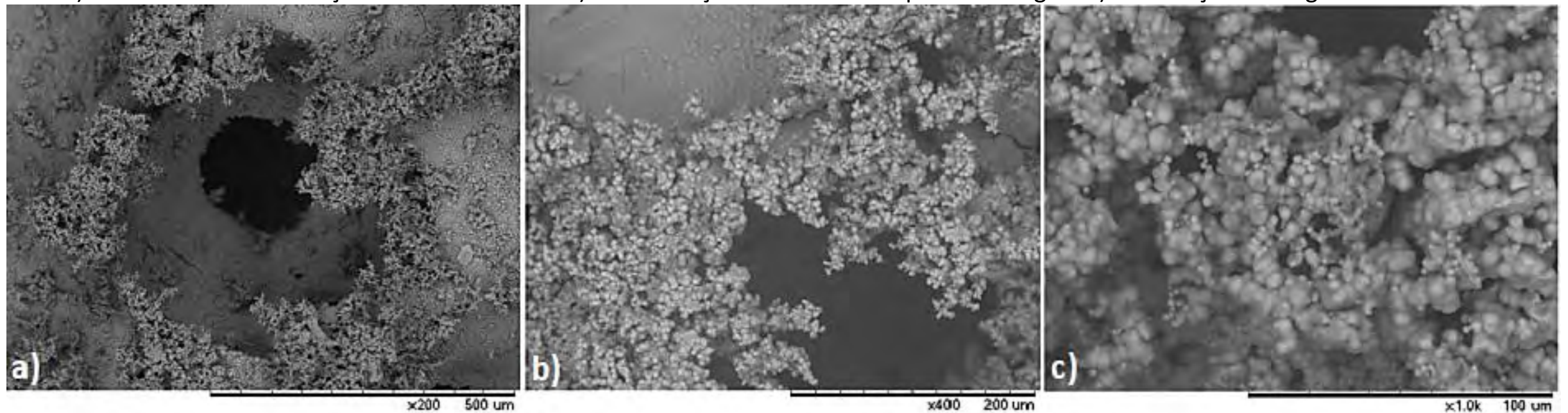

Figura 29 - Micrografias obtidas por MEV da superfície os corpos porosos de Alumina recobertas com tempo de incubação de 14 dias. Imagem a) destacando a distribuição do recobrimento b) a distribuição dos cristais no poros e Imagem c) a formação homogênea dos cristais.
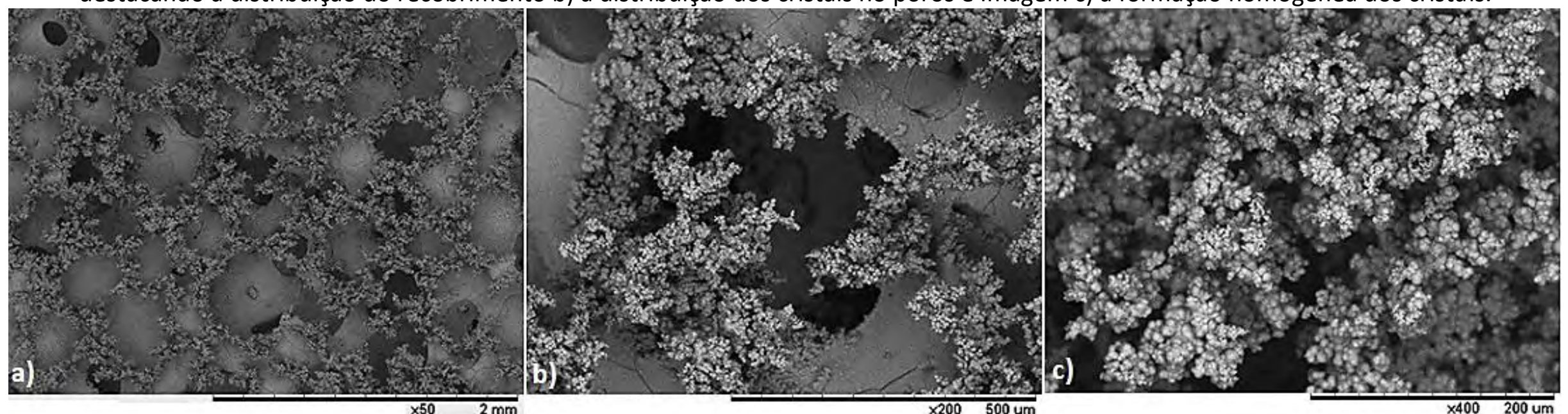
Figura 30 - Micrografias obtidas por MEV da superfície os corpos porosos de Alumina-Zircônia recobertas com tempo de incubação de 7 dias. Imagem a) destacando a distribuição do recobrimento b) a distribuição dos cristais no poros e Imagem c) a formação homogênea dos cristais.
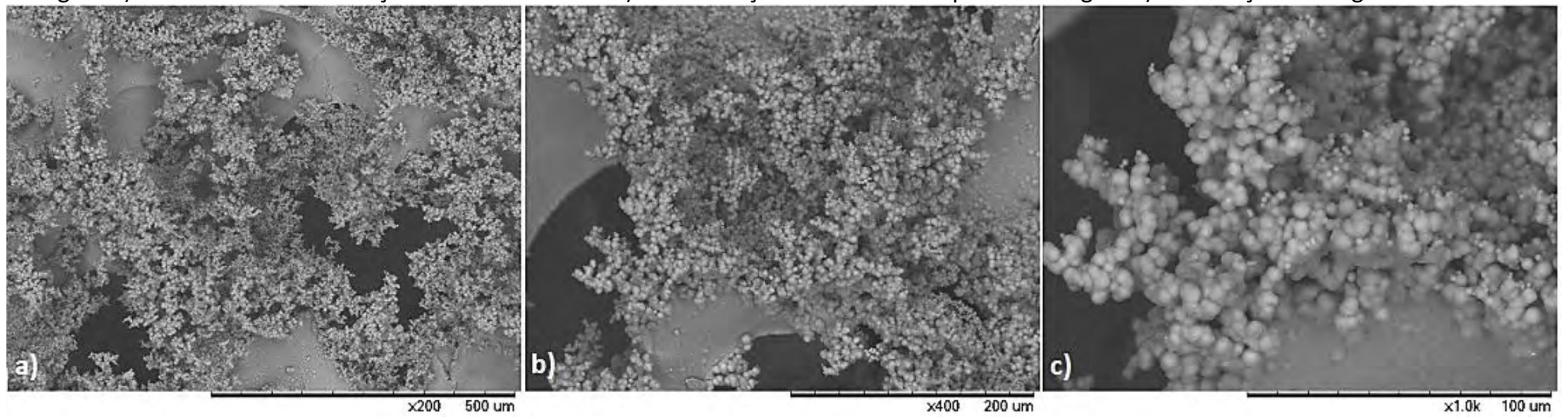

Figura 31 - Micrografias obtidas por MEV da superfície dos corpos porosos de Alumina-Zircônia recobertas com tempo de incubação de 14 dias. Imagem a) destacando a distribuição do recobrimento b) a distribuição dos cristais e Imagem c) a formação homogênea dos cristais.
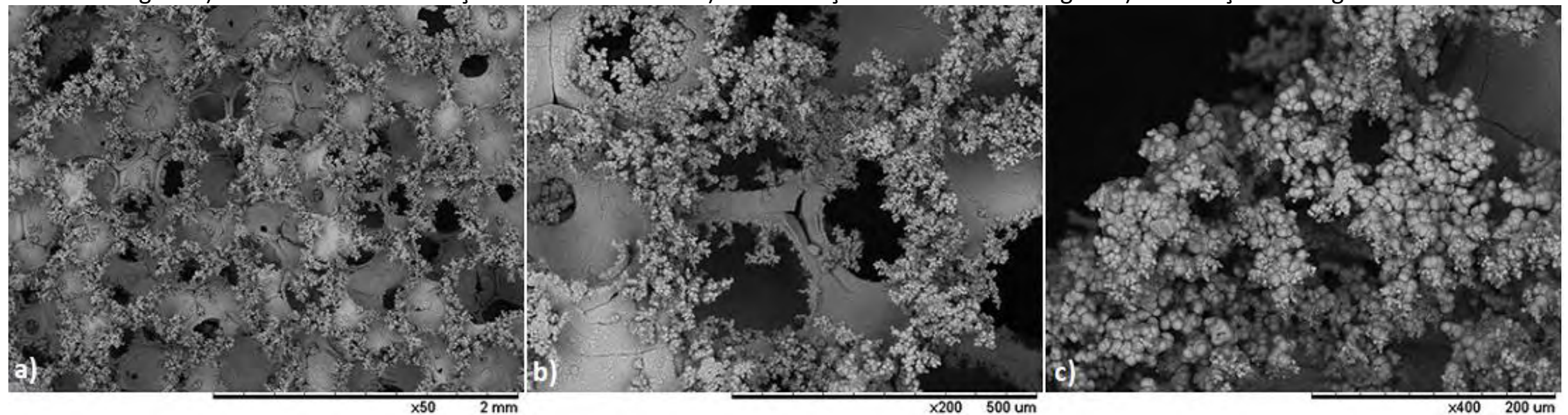
Com o período de incubação de 7 dias, como mostrado nas Figuras 28 e 30 foi possível observar que em todos corpos porosos ocorre a primeira etapa de formação da camada de fosfatos de cálcio sobre a superfície iniciando-se pela formação de pequenos núcleos. Após o período de incubação de 14 dias, como mostrado nas Figura 29 e Figura 31, são observados maior formação dos núcleos de fosfatos de cálcio. Os mesmos crescem espontaneamente consumindo os íons de cálcio (Ca) e fósforo $(P)$ presentes na solução saturada de SBF $5 x$ e na formação de suas fases (ABE et al., 1990). É observado ainda, que houver recobrimento nos poros e nas suas imediações.

A Figura 32 (a) e (b) apresenta, respectivamente, micrografias obtidas por MEV da superfície de fratura dos corpos porosos de $A$ e $A Z$ após período de incubação de 14 dias. Pode-se observar que houve penetração de glóbulos de fosfatos de cálcio em todos os poros de seu volume da matriz cerâmica.

Figura 32 - Micrografias obtidas por MEV da superfície de fratura dos corpos porosos após o período de incubação em SBF por 14 dias em a) corpo poroso de alumina e em b) corpo

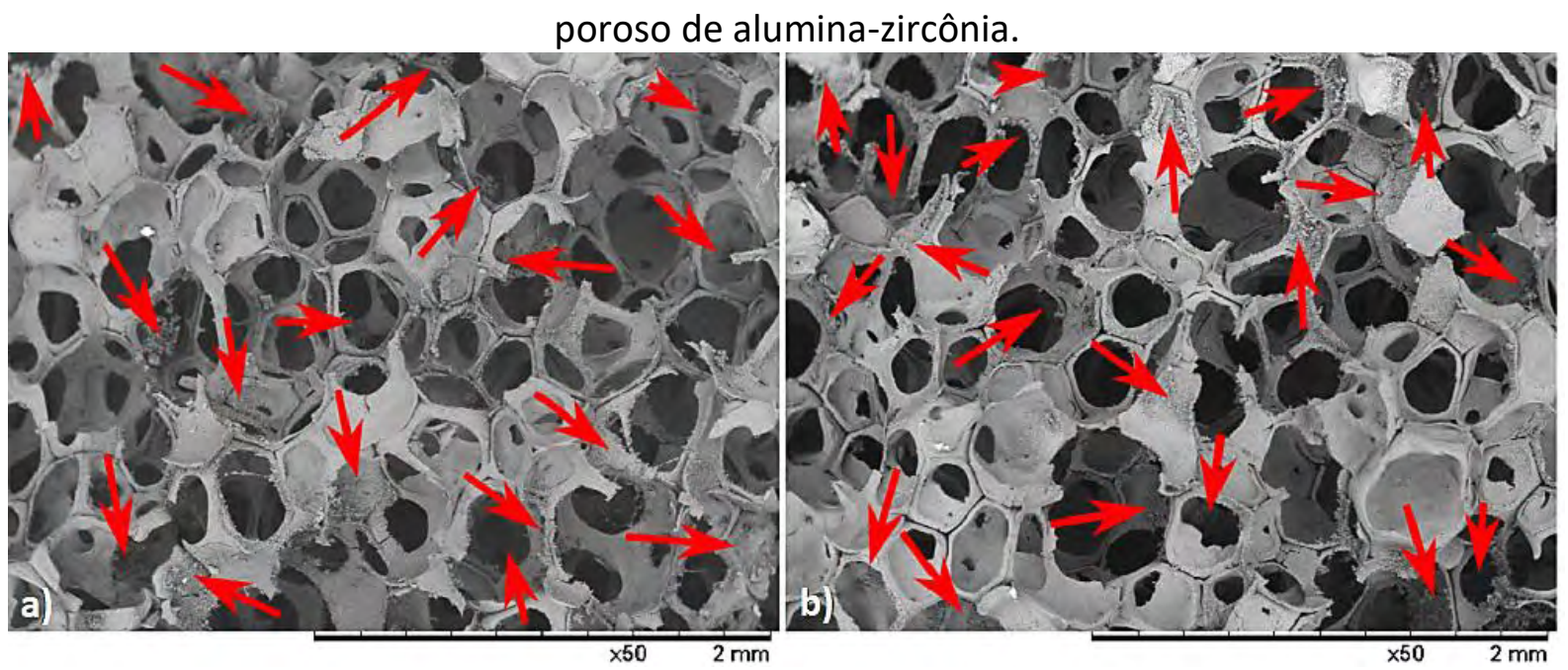

Tendo em vista a não existência de um mecanismo de formação de uma camada de fosfatos de cálcio sobre a superfície em materiais cerâmicos, pode-se considerar essa formação com base na composição de vidros e vitrocerâmicas (DOS SANTOS et al., 2017).

Segundo Hench (1998), a formação dos fosfatos ocorre inicialmente a dissolução dos íons de silicato presentes no vidro e adsorção destes ao substrado, seguida pela troca iônica entre a solução e a superfície. Isso ocorre liberando íons como $\mathrm{Na}^{+}, \mathrm{Ca}^{2+} \mathrm{e} \mathrm{PO}_{4}{ }^{3-}$. Após essa liberação, grupos silanóis sofrem a policondensação e dão origem a uma camada rica em sílica, 
que age como fonte de sítios para a nucleação heterogênea de fosfatos amorfos, cristalizandose em uma camada de apatita pela incorporação de ânions $\mathrm{OH}^{-} \mathrm{e} \mathrm{CO}_{3}{ }^{2-}$ na solução.

Em diversos trabalhos (FAGA et al., 2012; KOKUBO et al., 2009; UCHIDA et al, 2002), é observada a formação de fosfatos de cálcio sobre a superfície de diferentes materiais utilizando o método biomimético pode ser induzida pela presença de grupos funcionais hidroxilas $\left(\mathrm{OH}^{-}\right)$em cerâmicas e não apenas com composições vítreas.

Outra técnica também usada para caracterizar a razão $\mathrm{Ca} / \mathrm{P}$ foi a Espectroscopia de Energia Dispersiva de Raio X (EDS). A Tabela 17 apresenta a razão Ca/P e para os corpos porosos de $A, A Z$, analisados por períodos de 7, 14 e 21 dias de incubação. Essa análise foi baseada na média de 3 pontos em 3 regiões diferentes da superfície recoberta.

Tabela 17 - Relação Ca/P dos corpos porosos de alumina e alumina-zircônia usando a técnica de EDS, para todos os períodos de incubação de 7, 14 e 21 dias.

\begin{tabular}{|c|c|c|}
\hline \multicolumn{3}{|c|}{ Tratamento com $\mathrm{H}_{3} \mathrm{PO}_{4}$} \\
\hline $\begin{array}{c}\text { Corpo } \\
\text { Poroso }\end{array}$ & $\begin{array}{c}\text { Período de } \\
\text { incubação }\end{array}$ & $\mathbf{C a} / \mathbf{P}$ \\
\hline \multirow{3}{*}{ A } & 7 dias & $2,20 \pm 0,19$ \\
& 14 dias & $1,94 \pm 0,17$ \\
& 21 dias & $1,75 \pm 0,17$ \\
\hline \multirow{3}{*}{ AZ } & 7 dias & $2,02 \pm 0,18$ \\
\cline { 2 - 3 } & 14 dias & $1,87 \pm 0,06$ \\
& 21 dias & $1,79 \pm 0,15$ \\
\hline
\end{tabular}

Após 14 dias de incubação dos corpos porosos de alumina e alumina-zircônia em SBF $5 \mathrm{x}$, as razões $\mathrm{Ca} / \mathrm{P}$ foram de 1,94 e 1,87 para os corpos porosos tratadas quimicamente e recobertas, indicando que a camada de fosfatos de cálcio presente na superfície dos corpos porosos pode ser formada por fases de TTPC, de razão Ca/P igual a 2 .

Através dessa análise pôde-se selecionar o tempo de incubação (de 14 dias) e o tratamento químico, pois, ocorre um aumento da relação $\mathrm{Ca} / \mathrm{P}$ após o processo de biomineralização formando apatita carbonatada. Diversos trabalhos sugerem bioatividade in vitro após imersão em solução de SBF 5x no período de incubação de 14 dias (LOBO et al., 2013; SIQUEIRA et al., 2015)

De acordo com a Tabela 18, corpos porosos de $A$ e $A Z$ foram tratadas quimicamente com solução de Nitrato de Estrôncio $\left(\mathrm{Sr}\left(\mathrm{NO}_{3}\right)_{2}\right)$ com tempo de incubação de $48 \mathrm{H}$. 
Tabela 18 - Relação dos corpos porosos de alumina e alumina-zircônia, medidos através da técnica de EDS, para todos os períodos de incubação.

\begin{tabular}{c|c|c}
\hline $\begin{array}{c}\text { Corpo } \\
\text { poroso }\end{array}$ & $\begin{array}{c}\text { Período de } \\
\text { incubação do } \mathbf{S r}^{2+}\end{array}$ & $\frac{\mathbf{C a}+\mathbf{S r}}{\mathbf{P}}$ \\
\hline $\boldsymbol{A}(\boldsymbol{S})$ & $48 \mathrm{H}$ & $1,43 \pm 0,09$ \\
\hline $\boldsymbol{A Z}(\boldsymbol{S})$ & $48 \mathrm{H}$ & $1,42 \pm 0,09$ \\
\hline
\end{tabular}

Pode ser observado que a razão é discrepante dos valores obtidos no ensaio de ICPIOS, porém, observa-se que esse baixo valor, comparado aos corpos porosos não tratadas quimicamente, significando a substituição parcial do $\mathrm{Ca}^{2+}$ pelo $\mathrm{Sr}^{2+}$. Essa discrepância está relacionada à superfície material ser poroso, não tendo uma uniformidade na distribuição dos pontos medidos.

\subsubsection{Cultura de Células}

Nos ensaios de cultura de células os corpos porosos são identificados da seguinte forma: A e AZ (cerâmicas porosas sem nenhum tipo de tratamento), A-T e AZ-T (cerâmicas porosas tratadas quimicamente com $\mathrm{H}_{3} \mathrm{PO}_{4}$ ) e A-T-Rec e AZ-T-Rec (cerâmicas porosas tratadas quimicamente com $\mathrm{H}_{3} \mathrm{PO}_{4}$ e recobertas com solução de SBF 5x com 14 dias de incubação).

\section{Ensaio de citotoxicidade}

A Figura 33 apresenta a análise de viabilidade celular, frente aos osteoblastos humanos MG-63.

Figura 33 - Gráfico representativo das porcentagens médias de absorbância, obtidas de viabilidade celular, após contato das células com os corpos porosos de alumina e

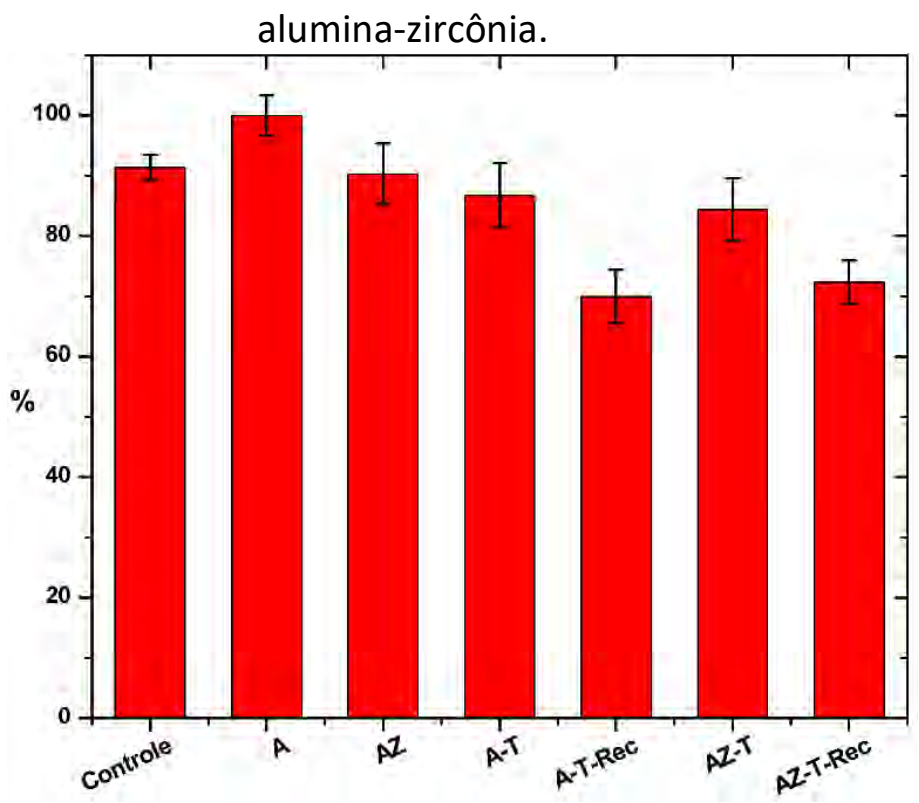


Os resultados encontrados demostraram que o material, independentemente do tipo e do tratamento usado, não é tóxico para as células nas condições experimentais utilizadas e também possuem valores de absorbância estatisticamente próximos entre si. O gráfico foi normalizado pelo valor mínimo de percentagem do corpo poroso A-T-Rec. Considerando que valores tóxicos são encontrados abaixo de 70 \% (ISO, 1999).

A análise de LDH liberado após $24 \mathrm{~h}$ de cultivo dos osteoblastos humanos sobre os materiais demostrou que as cerâmicas não são tóxicas para as células. O controle positivo de morte e ANOVA * $p<5 \%$ vs controle.

Após 14 dias de cultura celular a formação de nódulos de mineralização foi quantificada e os resultados expressos em densidade óptica, como mostrados na Figura 34.

Figura 34 - Gráfico representativo da quantificação dos nódulos de mineralização dos corpos porosos de alumina e alumina-zircônia.

Nódulos de Mineralização

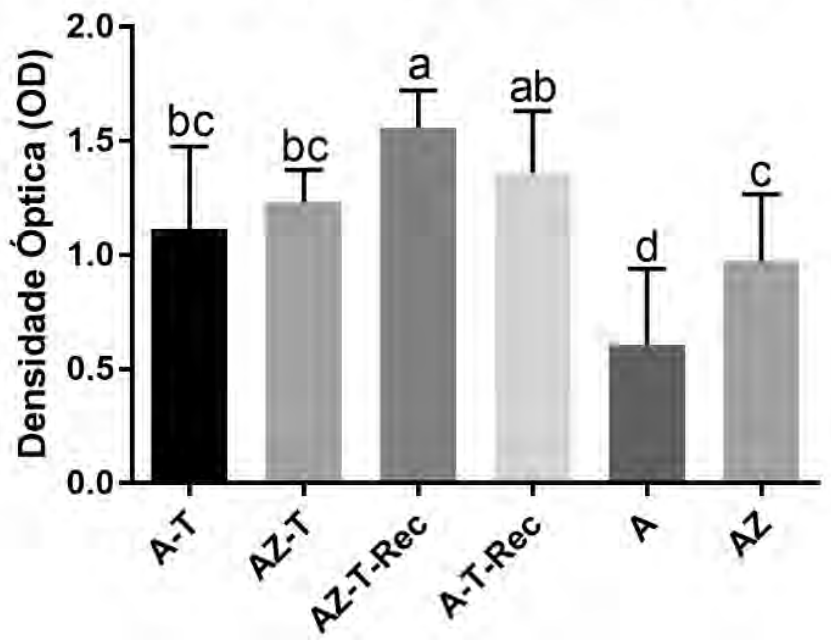

Após a quantificação dos nódulos de mineralização, o grupo A-T-Rec apresentou o valor mais alto de formação de nódulos, não diferindo estatisticamente apenas do grupo AZT-Rec ( $p>0.05)$. Já o grupo AZ-T-Rec demonstrou diferença estatística com os grupos $A$ e $A Z$ $(p<0.05)$. A menor quantidade de formação de matriz mineralizada foi observada no grupo A, a qual diferiu estatisticamente de todos os grupos $(p<0.05)$.

Os resultados mostraram que, quando osteoblastos foram cultivados em grupos de corpos porosos, ocorreu uma maior deposição de cálcio em comparação com o controle. 
Os resultados indicaram que a arquitetura dos corpos porosos, semelhante à matriz extracelular e, o tratamento químico com $\mathrm{H}_{3} \mathrm{PO}_{4}$ melhorou a aderência, uniformidade e bioatividade junto a camada de fosfato de cálcio depositada induzindo maior formação de fases com subsequente mineralização. Esses efeitos podem estar atribuídos às fases formadas, como a hidroxiapatita carbonatada e o TTCP identificado nas análises de DRX.

O corpo poroso de AZ-T-Rec destacou-se pela grande formação dos nódulos de mineralização. Esse resultado está de acordo com os mesmos identificados anteriormente, mostrando-se promissor o tratamento químico com ácido e o recobrimento utilizando SBF 5x em um período menor, 14 dias. Esse período de incubação, já mostrado em diversos trabalhos (LOBO et al., 2013; ZANIN, H et al., 2015) é confirmado e inédito a sua utilização nos corpos porosos produzidos pelo método da réplica com a composição de alumina com inclusões de zircônia (5\%vol).

Os resultados obtidos pelas avaliações in vitro corroboram com a análise de $\mathrm{pH}$ mostrando que os corpos porosos são promissores na aplicação como materiais pera substituição e preenchimento ósseo. 


\section{Conclusões}

De acordo com os resultados obtidos no trabalho, pôde-se concluir e ressaltar que:

- O método da réplica foi eficiente para a obtenção de cerâmicas porosas de alumina e alumina-zircônia, sendo que estas apresentaram uma ampla faixa no tamanho de porosidade, estrutura de célula aberta, alta permeabilidade e resistência mecânica próxima do osso poroso.

- Os métodos de mistura de suspensões mostraram-se eficiente na dispersão das inclusões de $\mathrm{ZrO}_{2}$ na matriz $\mathrm{Al}_{2} \mathrm{O}_{3}$, sendo estas distribuídas uniformemente na matriz de $\mathrm{Al}_{2} \mathrm{O}_{3}$;

- Utilizando o recobrimento biomimético com SBF 5X mais concentrado observou uma ampla formação de fases de fosfatos de cálcio (formação de $\alpha$-TCP, $\beta$-TCP, TTCP e Hidroxiapatita) nos corpos porosos de alumina e alumina-zircônia, tratados com $\mathrm{H}_{3} \mathrm{PO}_{4}$, utilizando tempo de incubação de 14 dias;

- Houve penetração de cristais de fosfatos de cálcio no interior dos corpos porosos, em ambas as composições estudadas;

- Os resultados mostraram que o $\mathrm{Sr}^{2+}$ foi capaz de entrar na estrutura de apatita (e suas fases de fosfato de cálcio) e os corpos porosos de alumina-zircônia apresentaram maior aptidão em formar fosfato de estrôncio que os corpos porosos de alumina;

- Os ensaios in vitro de viabilidade celular realizados mostraram a não citotoxicidade dos corpos porosos de alumina e alumina-zircônia, ocorrendo uma maior deposição de cálcio nos corpos porosos de alumina-zircônia em comparação com o controle para a formação de nódulos de mineralização.

- Os resultados de modo geral demostraram de maneira geral que as cerâmicas porosas estudadas têm potencial para serem utilizadas na substituição ou preenchimento ósseo. 


\section{Sugestões para trabalhos futuros}

Como sugestão para trabalhos futuros tem-se:

- Analisar, através da $\mu \mathrm{CT}$, os corpos porosos recobertos com fosfatos de cálcio;

- Melhor investigação das fases de fosfatos de cálcio formadas a partir do método biomimético utilizando Infravermelho (IV);

- Utilizar o método de recobrimento biomimético com concentração do SBF $1,5 x$ elucidando um comparativo dos resultados contidos;

- Realizar estudos in vivo dos corpos porosos estudados. 


\section{Anexo 1}

Composições feitas como testes para o desenvolvimento deste trabalho.

\section{1ㅁ Fase}

Na primeira fase de testes, foram utilizados álcool Polivinílico (PVA) - (Industrializado por VETEC QUÍMICA FINA); silicato de sódio - (Industrializado por VETEC QUÍMICA FINA); Poliacrilatos de amônia - Disperlan LA (Lambra); alumina da Alcoa CT3000SG, (Alcoa \& Chemicals Ltda) com diâmetro médio equivalente de partícula de 0,6 $\mu \mathrm{m}$, área superficial de 6 a $8 \mathrm{~m}^{2} / \mathrm{g}$ e alumina AKP-53 produzida pela Sumitomo Chemical, Japão, com tamanho médio de partículas em torno de 0,25 $\mu \mathrm{m}$, área superficial específica de 13,6 $\mathrm{m}^{2} / \mathrm{g}$ e pureza de 99,995\%, dados fornecidos pelo fabricante. Na Tabela 19, está apresentado os reagentes e sua proporções utilizados na produção dos corpos porosos.

\begin{tabular}{|c|c|}
\hline Composição (\% peso) & Alumina \\
\hline $55 \mathrm{Al}_{2} \mathrm{O}_{3}+5 \mathrm{PVA}+1 \mathrm{Na}_{2} \mathrm{SiO}_{3}+39 \mathrm{H}_{2} \mathrm{O}$ & AKP \\
\hline $55 \mathrm{Al}_{2} \mathrm{O}_{3}+5 \mathrm{PVA}+1 \mathrm{Na}_{2} \mathrm{SiO}_{3}+39 \mathrm{H}_{2} \mathrm{O}$ & Alcoa \\
\hline $55 \mathrm{Al}_{2} \mathrm{O}_{3}+5 \mathrm{PVA}+1 \mathrm{Na}_{2} \mathrm{SiO}_{3}+39 \mathrm{H}_{2} \mathrm{O}$ (vácuo) & AKP \\
\hline $55 \mathrm{Al}_{2} \mathrm{O}_{3}+5 \mathrm{PVA}+1 \mathrm{Na}_{2} \mathrm{SiO}_{3}+39 \mathrm{H}_{2} \mathrm{O}$ (vácuo) & Alcoa \\
\hline $60 \mathrm{Al}_{2} \mathrm{O}_{3}+10 \mathrm{PVA}+\mathrm{PMMA}+28,9 \mathrm{H}_{2} \mathrm{O}+0,1 \mathrm{CMC}$ & Alcoa \\
\hline $60 \mathrm{Al}_{2} \mathrm{O}_{3}+10 \mathrm{PVA}+\mathrm{PMMA}+28,9 \mathrm{H}_{2} \mathrm{O}+0,13 \mathrm{CMC}$ & Alcoa \\
\hline
\end{tabular}

Na segunda fase do trabalho, foram feitos diversos testes com o pó de alumina AKP e a o pó de zircônia na forma nanométrica parcialmente estabilizada (3 \% mol ytria), produzida pela Nanostructured \& Amorphous Materials Inc. (MA-USA), com tamanho médio de partículas em torno de 30-65 $\mathrm{nm}$, área superficial 19,8 $\mathrm{m}^{2} / \mathrm{g}$ e pureza de $99,9 \%$ utilizando o método de preparação do ítem 4.1. Na Tabela 20, está apresentado os reagentes e sua proporções utilizados na produção dos corpos porosos. 
2a Fase

Tabela 20- Reagentes utilizados, como teste, na produção dos corpos de prova porosos da fase 2.

\begin{tabular}{l|l|l|l|l}
\hline Produto & \multicolumn{4}{l}{ Percentagem } \\
\hline & D & B & C & I \\
Alumina (AKP) & 55 & 48 & 55 & 51,44 \\
Poliacrilato de amônia & 1,89 & 1,7 & 1,7 & 0,772 \\
(PMMA) & & & & \\
Glicerina & 3,03 & 3,0 & 3,0 & 2,352 \\
Polietileno glicol & 0,77 & 0,70 & 0,7 & 0,588 \\
Ácido oléico & 0,44 & 0,30 & 0,3 & 0,294 \\
Solução CMC & 1,09 & 1,0 & 1 & 0,94 \\
Solução PVA & 11,77 & 20 & 15 & 30,097 \\
Água & 26,01 & 25,30 & 23,3 & 13,520 \\
\hline
\end{tabular}




\section{BIBLIOGRAFIA}

ABE, Y.; KOKUBO, T.; YAMAMURO, T. Apatite coating on ceramics, metals and polymers utilizing a biological process. Journal of Materials Science: Materials in Medicine, v. 1, n. 4, p. 233-238, 1990/11/01 1990.

ACCHAR, W.; SOUZA, F.; RAMALHO, E.; TORQUATO, W. Mechanical characterization of cellular ceramics. Materials Science and Engineering: A, v. 513, p. 340-343, 2009.

ACCHAR, W.; SOUZA, F. B. M.; RAMALHO, E. G.; TORQUATO, W. L. Mechanical characterization of cellular ceramics. Materials Science and Engineering: A, v. 513-514, n. 0, p. 340-343, 2009.

AENUGU, H. P. R.; KUMAR, D. S.; SRISUDHARSON, N. P.; GHOSH, S. S.; BANJI, D. Near Infra Red Spectroscopy-An Overview. International Journal of ChemTech Research, v. 3, n. 2, p. 825836, 2011.

AFZAL, A. Implantable zirconia bioceramics for bone repair and replacement: A chronological review. Materials Express, v. 4, n. 1, p. 1-12, 2014.

AGUIAR, A. A.; USSUI, V.; RIBEIRO, C.; SCAPIN, M. A.; RIBEIRO RICCI, D.; DE LIMA, N. B. Characterization of the apatite formation on the surfaces of zirconia and alumina ceramics in body environments. Materials Science Forum, 2008. Trans Tech Publ. p.697-702.

AINA, V.; LUSVARDI, G.; ANNAZ, B.; GIBSON, I. R.; IMRIE, F. E.; MALAVASI, G.; MENABUE, L.; CERRATO, G.; MARTRA, G. Magnesium-and strontium-co-substituted hydroxyapatite: the effects of doped-ions on the structure and chemico-physical properties. Journal of Materials Science: Materials in Medicine, v. 23, n. 12, p. 2867-2879, 2012.

ALVES, H. L. R.; STAINER, D.; BERGMANN, C. P. Método alternativo para fabricação de cabeça femoral cerâmica para próteses de quadril. Revista brasileira de engenharia biomédica= Brazilian journal of biomedical engineering. Vol. 20, n. 2/3 (Dez. 2004), p. 81-88, 2004.

ANTONIAC, I. V. Handbook of Bioceramics and Biocomposites. Springer, 2016. ISBN 3319124595.

AOBA, T. The effect of fluoride on apatite structure and growth. Critical Reviews in Oral Biology \& Medicine, v. 8, n. 2, p. 136-153, 1997.

AOKI, H. Science and medical applications of hydroxyapatite. Ishiyaku Euroamerica, 1991. ISBN 1563860074.

ASTM. C373-88 -Standard Test Method for Water Absorption, Bulk Density, Apparent Porosity, and Apparent Specific Gravity of Fired Whiteware Products. USA 1999.

C326 - 09 - Standard Test Method for Drying and Firing Shrinkages of Ceramic Whiteware Clays 2014a. 

Medical Application. USA: 1-3 p. 2014b.

B. SUBIA, J. K., S. C. KUNDU. Biomaterial Scaffold Fabrication Techniques for Potential Tissue Engineering Applications, Tissue Engineering. In: EBERLI, D. (Ed.), 2010. ISBN 978-953-307079-7.

BALDACIM, S.; CAIRO, C.; SILVA, C. Mechanical properties of ceramic composites. Journal of Materials Processing Technology, v. 119, n. 1, p. 273-276, 2001.

BARRERE, F.; VAN BLITTERSWIJK, C.; DE GROOT, K.; LAYROLLE, P. Influence of ionic strength and carbonate on the Ca-P coating formation from SBFx 5 solution. Biomaterials, v. 23, n. 9, p. 1921-1930, 2002.

BARRERE, F.; VAN BLITTERSWIJK, C. A.; DE GROOT, K.; LAYROLLE, P. Influence of ionic strength and carbonate on the Ca-P coating formation from SBFx5 solution. Biomaterials, v. 23, n. 9, p. 1921-1930, May 2002.

BAYRAKTAR, D.; TAŞ, A. C. Biomimetic preparation of HA powders at $37 \mathrm{C}$ in urea-and enzyme urease-containing synthetic body fluids. Turkish Journal of Medical Sciences, v. 30, n. 3, p. 235-246, 2000.

BEN-NISSAN, B. Advances in Calcium Phosphate Biomaterials. 2014.

BOANINI, E.; PANZAVOLTA, S.; RUBINI, K.; GANDOLFI, M.; BIGI, A. Effect of strontium and gelatin on the reactivity of $\alpha$-tricalcium phosphate. Acta biomaterialia, v. 6, n. 3, p. 936-942, 2010.

BURG, K. J. L.; PORTER, S.; KELLAM, J. F. Biomaterial developments for bone tissue engineering. Biomaterials, v. 21, n. 23, p. 2347-2359, 2000.

CALLISTER, W. D.; RETHWISCH, D. G. Materials science and engineering. John Wiley \& Sons NY, 2011.

CAMILO, C. C.; FORTULAN, C.; IKEGAMI, R.; SANTOS, A. R.; DE M PURQUERIO, B. Manufacturing of porous alumina scaffolds with bio-glass and HAp coating: Mechanical and in vitro evaluation. Key Engineering Materials, v. 396, p. 679-682, 2009.

CARVALHO, P.; ROSA, A.; BASSI, A.; PEREIRA, L. Biomateriais aplicados a Implantodontia. Rev Implant News, v. 7, n. 3a, p. 56-65, 2010.

CAVALU, S.; BANICA, F.; SIMON, V.; AKIN, I.; GOLLER, G. Surface Modification of Alumina/Zirconia Ceramics Upon Different Fluoride-Based Treatments. International Journal of Applied Ceramic Technology, v. 11, n. 2, p. 402-411, 2014. 
CHEN, F.-M.; LIU, X. Advancing biomaterials of human origin for tissue engineering. Progress in polymer science, v. 53, p. 86-168, 2016.

CHINELATTO, A. S. A.; CHINELATTO, A. L.; OJAIMI, C. L.; FERREIRA, J. A.; PALlONE, E. M. D. J. A. Effect of sintering curves on the microstructure of alumina-zirconia nanocomposites. Ceramics International, v. 40, n. 9, p. 14669-14676, 2014.

COLOMBO, P., HELLMANN, J.R. Ceramic foams: fabrication, properties and application. In Key Engineering Materials. Trans Tech Publications, v. 206-213, p. 1913-1918, 2002.

COMAR, C. L.; BRONNER, F. Mineral metabolism: An advanced treatise. Academic Press, 1960.

COSTA, H. S.; MANSUR, A. A.; BARBOSA-STANCIOLI, E. F.; PEREIRA, M. M.; MANSUR, H. S. Morphological, mechanical, and biocompatibility characterization of macroporous alumina scaffolds coated with calcium phosphate/PVA. Journal of Materials science, v. 43, n. 2, p. 510524, 2008.

COSTA, H. S.; MANSUR, A. A. P.; BARBOSA-STANCIOLI, E.; PEREIRA, M.; MANSUR, H. Morphological, mechanical, and biocompatibility characterization of macroporous alumina scaffolds coated with calcium phosphate/PVA. Journal of Materials Science, v. 43, n. 2, p. 510524, 2008/01/01 2008.

CRANIN, A. N. Biomaterials: An interfacial approach, L. L. Hench and E. C. Ethridge, New York, Academic, 1982, 384 pp. 14 Chapters, Glossary, Bibliography, and Index. Journal of Biomedical Materials Research, v. 19, n. 5, p. 611-612, 1985.

CRANIN, A. N. Biomaterials: An interfacial approach, LL Hench and EC Ethridge, New York, Academic, 1982, 384 pp. 14 Chapters, Glossary, Bibliography, and Index. Price: \$42.00: Wiley Online Library 1985.

CROTEAU, S.; RAUCH, F.; SILVESTRI, A.; HAMDY, R. C. Bone morphogenetic proteins in orthopedics: from basic science to clinical practice. Orthopedics, v. 22, n. 7, p. 686-695, 1999.

CROVACE, M. C. Obtenção de estruturas porosas altamente bioativas via sinterização do Biosilicato. 2010.

DAHL, S.; ALLAIN, P.; MARIE, P.; MAURAS, Y.; BOIVIN, G.; AMMANN, P.; TSOUDEROS, Y.; DELMAS, P.; CHRISTIANSEN, C. Incorporation and distribution of strontium in bone. Bone, $v$. 28, n. 4, p. 446-453, 2001.

DENRY, I.; KUHN, L. T. Design and characterization of calcium phosphate ceramic scaffolds for bone tissue engineering. Dental materials, v. 32, n. 1, p. 43-53, 2016.

DOS SANTOS, K. H.; FERREIRA, J. A.; OSIRO, D.; DA CONCEIÇÃO, G. J. A.; FILHO, R. B.; COLNAGO, L. A.; DE JESUS AGNOLON PALLONE, E. M. Influence of different chemical treatments on the 
surface of $\mathrm{Al} 2 \mathrm{O} 3 / \mathrm{ZrO} 2$ nanocomposites during biomimetic coating. Ceramics International, v. 43, n. 5, p. 4272-4279, 2017.

DRLESSEN, A.; KLEIN, C.; GROOT, K. Preparation and some properties of sintered $\beta$-whitiockite. Biomaterials, v. 3, n. 2, p. 113-116, 1982.

ELLIOTT, J. C. Structure and chemistry of the apatites and other calcium orthophosphates. Elsevier, 2013. ISBN 148329031X.

FAGA, M.; VALLÉE, A.; BELLOSI, A.; MAZZOCCHI, M.; THINH, N.; MARTRA, G.; COLUCCIA, S. Chemical treatment on alumina-zirconia composites inducing apatite formation with maintained mechanical properties. Journal of the European Ceramic Society, v. 32, n. 10, p. 2113-2120, 2012.

FAGA, M. G.; VALLÉE, A.; BELLOSI, A.; MAZZOCCHI, M.; THINH, N. N.; MARTRA, G.; COLUCCIA, $S$. Chemical treatment on alumina-zirconia composites inducing apatite formation with maintained mechanical properties. Journal of the european ceramic society, v. 32, n. 10, p. 2113-2120, 2012.

FENG, P.; WEI, P.; SHUAI, C.; PENG, S. Characterization of mechanical and biological properties of 3-D scaffolds reinforced with zinc oxide for bone tissue engineering. PloS one, v. 9, n. 1, p. e87755, 2014.

FONSECA, F. Biocerâmicas porosas bifásicas e trifásicas à base de hidroxiapatita produzidas por gelcasting. 2007. 2007. Dissertação (Mestrado em Ciências dos Materiais), Instituto Militar de Engenharia

GARTNER, L. P.; HIATT, J. L. Tratado de histologia. Elsevier Brasil, 2011. ISBN 8535245782.

GÓMEZ, S.; VLAD, M.; LÓPEZ, J.; FERNÁNDEZ, E. Design and properties of 3D scaffolds for bone tissue engineering. Acta biomaterialia, v. 42, p. 341-350, 2016.

GÓMEZ, S. Y.; ALVAREZ, O. A.; ESCOBAR, J. A.; RODRIGUES NETO, J. B.; RAMBO, C. R.; HOTZA, D. Relationship between Rheological Behaviour and Final Structure of Al. Advances in Materials Science and Engineering, v. 2012, p. 9, 2012.

GOVINDARAJ, D.; RAJAN, M.; MUNUSAMY, M. A.; HIGUCHI, A. Mineral substituted hydroxyapatite coatings deposited on nanoporous TiO 2 modulate the directional growth and activity of osteoblastic cells. RSC Advances, v. 5, n. 73, p. 58980-58988, 2015.

GREGORY, C. A.; GRADY GUNN, W.; PEISTER, A.; PROCKOP, D. J. An Alizarin red-based assay of mineralization by adherent cells in culture: comparison with cetylpyridinium chloride extraction. Analytical Biochemistry, v. 329, n. 1, p. 77-84, 2004/06/01/ 2004.

GROSS, U.; MÜLLER-MAI, C.; VOIGT, C. The interface of calcium-phosphate and glass-ceramic in bone, a structural analysis. Biomaterials, v. 11, p. 83-85, 1990. 
GRYNPAS, M.; HAMILTON, E.; CHEUNG, R.; TSOUDEROS, Y.; DELOFFRE, P.; HOTT, M.; MARIE, $P$. Strontium increases vertebral bone volume in rats at a low dose that does not induce detectable mineralization defect. Bone, v. 18, n. 3, p. 253-259, 1996.

GUASTALDI, A. C.; APARECIDA, A. H. Fosfatos de cálcio de interesse biológico: importância como biomateriais, propriedades e métodos de obtenção de recobrimentos. Química nova, p. 1352-1358, 2010.

GUIMARAES, F. A.; SILVA, K. L.; TROMBINI, V.; PIERRI, J. J.; RODRIGUES, J. A.; TOMASI, R.; PALLONE, E. M. Correlation between microstructure and mechanical properties of Al 20 3/ZrO 2 nanocomposites. Ceramics International, v. 35, n. 2, p. 741-745, 2009.

GUIMARÃES, F. A. T.; SILVA, K. L.; TROMBINI, V.; PIERRI, J. J.; RODRIGUES, J. A.; TOMASI, R.; PALLONE, E. M. J. A. Correlation between microstructure and mechanical properties of Al2O3/ZrO2 nanocomposites. Ceramics International, v. 35, n. 2, p. 741-745, 2009.

GUO, D.; XU, K.; ZHAO, X.; HAN, Y. Development of a strontium-containing hydroxyapatite bone cement. Biomaterials, v. 26, n. 19, p. 4073-4083, 2005.

HABRAKEN, W.; HABIBOVIC, P.; EPPLE, M.; BOHNER, M. Calcium phosphates in biomedical applications: materials for the future? Materials today, v. 19, n. 2, p. 69-87, 2016.

HANIFI, A.; FATHI, M.; SADEGHI, H. M. M. Effect of strontium ions substitution on gene delivery related properties of calcium phosphate nanoparticles. Journal of materials science: Materials in medicine, v. 21, n. 9, p. 2601-2609, 2010.

HASHMI, M. U.; SHAH, S. A. Dissolution behavior of bioactive glass ceramics with different $\mathrm{CaO} / \mathrm{MgO}$ ratios in SBF-K9 and r-SBF. Progress in Natural Science: Materials International, v. 24, n. 4, p. 354-363, 2014/08/01/ 2014.

HE, X.; ZHANG, Y. Z.; MANSELL, J. P.; SU, B. Zirconia toughened alumina ceramic foams for potential bone graft applications: fabrication, bioactivation, and cellular responses. Journal of Materials Science: Materials in Medicine, v. 19, n. 7, p. 2743-2749, 2008/07/01 2008.

HENCH, L. L. Biomaterials: a forecast for the future. Biomaterials, v. 19, n. 16, p. 1419-1423, 1998.

HENCH, L. L.; WILSON, J. An introduction to bioceramics. World scientific, 1993. ISBN 9814504165.

IAFISCO, M.; RUFFINI, A.; ADAMIANO, A.; SPRIO, S.; TAMPIERI, A. Biomimetic magnesiumcarbonate-apatite nanocrystals endowed with strontium ions as anti-osteoporotic trigger. Materials Science and Engineering: C, v. 35, p. 212-219, 2014.

INNOCENTINI, M. D. M.; SEPULVEDA, P.; SALVINI, V. R.; PANDOLFELLI, V. C.; COURY, J. R. Permeability and Structure of Cellular Ceramics: A Comparison between Two Preparation Techniques. Journal of the American Ceramic Society, v. 81, n. 12, p. 3349-3352, 1998. 
ISHIKAWA, T.; WAKAMURA, M.; KONDO, S. Surface characterization of calcium hydroxylapatite by Fourier transform infrared spectroscopy. Langmuir, v. 5, n. 1, p. 140-144, 1989.

ISO-FDIS23317. Implants for surgery - In vitro evaluation for apatite-forming ability of implant materials 2005.

ISO, B. 10993-5: Biological evaluation of medical devices. Tests for in vitro cytotoxicity, 1999.

ITÄLÄ, A. I.; YLÄNEN, H. O.; EKHOLM, C.; KARLSSON, K. H.; ARO, H. T. Pore diameter of more than $100 \mu \mathrm{m}$ is not requisite for bone ingrowth in rabbits. Journal of biomedical materials research, v. 58, n. 6, p. 679-683, 2001.

JONÁŠOVÁ, L.; MÜLLER, F. A.; HELEBRANT, A.; STRNAD, J.; GREIL, P. Biomimetic apatite formation on chemically treated titanium. Biomaterials, v. 25, n. 7, p. 1187-1194, 2004.

JONES, J. R.; TSIGKOU, O.; COATES, E. E.; STEVENS, M. M.; POLAK, J. M.; HENCH, L. L. Extracellular matrix formation and mineralization on a phosphate-free porous bioactive glass scaffold using primary human osteoblast (HOB) cells. Biomaterials, v. 28, n. 9, p. 1653-1663, 2007.

JUNQUEIRA, L.; CARNEIRO, J. Hemocitopoese. Histologia básica, p. 238-253, 2004.

KALITA, S. J.; BHARDWAJ, A.; BHATT, H. A. Nanocrystalline calcium phosphate ceramics in biomedical engineering. Materials Science and Engineering: C, v. 27, n. 3, p. 441-449, 2007.

KAWACHI, E. Y.; BERTRAN, C. A.; REIS, R. R. D.; ALVES, O. L. Bioceramics: tendencies and perspectives of an interdisciplinary area. Química Nova, v. 23, n. 4, p. 518-522, 2000.

KIDO, H. W.; RIBEIRO, D. A.; DE OLIVEIRA, P.; PARIZOTTO, N. A.; CAMILO, C. C.; FORTULAN, C. A.; MARCANTONIO, E.; DA SILVA, V. H. P.; MUNIZ RENNO, A. C. Biocompatibility of a porous alumina ceramic scaffold coated with hydroxyapatite and bioglass. Journal of Biomedical Materials Research Part A, v. 102, n. 7, p. 2072-2078, 2014.

KIM, H. M.; HIMENO, T.; KAWASHITA, M.; KOKUBO, T.; NAKAMURA, T. The mechanism of biomineralization of bone-like apatite on synthetic hydroxyapatite: an in vitro assessment. Journal of the Royal Society, Interface / the Royal Society, v. 1, n. 1, p. 17-22, Nov 222004.

KLAWITTER, J.; HULBERT, S. Application of porous ceramics for the attachment of load bearing internal orthopedic applications. Journal of Biomedical Materials Research Part A, v. 5, n. 6, p. 161-229, 1971a.

Application of porous ceramics for the attachment of load bearing internal orthopedic applications. Journal of biomedical materials research, v. 5, n. 6, p. 161-229, 1971b. 
KOKUBO, T.; KUSHITANI, H.; SAKKA, S.; KITSUGI, T.; YAMAMURO, T. Solutions able to reproduce in vivo surface-structure changes in bioactive glass-ceramic A-W3. Journal of biomedical materials research, v. 24, n. 6, p. 721-734, 1990.

KOKUBO, T.; MATSUSHITA, T.; TAKADAMA, H.; KIZUKI, T. Development of bioactive materials based on surface chemistry. Journal of the european ceramic society, v. 29, n. 7, p. 12671274, 2009.

KOLMAS, J.; MAREK, D.; KOLODZIEJSKI, W. Near-Infrared (NIR) Spectroscopy of Synthetic Hydroxyapatites and Human Dental Tissues. Applied spectroscopy, v. 69, n. 8, p. 902-912, 2015.

KOUTSOPOULOS, S. Synthesis and characterization of hydroxyapatite crystals: a review study on the analytical methods. Journal of biomedical materials research, v. 62, n. 4, p. 600-612, 2002.

KURTZ, S. M.; KOCAGÖZ, S.; ARNHOLT, C.; HUET, R.; UENO, M.; WALTER, W. L. Advances in zirconia toughened alumina biomaterials for total joint replacement. Journal of the mechanical behavior of biomedical materials, v. 31, p. 107-116, 2014.

KWON, S. H.; JUN, Y. K.; HONG, S. H.; LEE, I. S.; KIM, H. E.; WON, Y. Y. Calcium phosphate bioceramics with various porosities and dissolution rates. Journal of the American Ceramic Society, v. 85, n. 12, p. 3129-3131, 2002.

L. MONTANARO, Y. J., G. FANTOZZI, A. NEGRO. Ceramic foams by powder processing. Journal of the European Ceramic Society, v. 18, n. 9, p. 1339-1350, 1998.

LAONAPAKUL, T. Synthesis of hydroxyapatite from biogenic wastes. KKU ENGINEERING JOURNAL, v. 42, n. 3, p. 269-275, 2015.

LEGEROS, R. Z. Biodegradation and bioresorption of calcium phosphate ceramics. Clinical materials, v. 14, n. 1, p. 65-88, 1993.

LI, Y.; LI, Q.; ZHU, S.; LUO, E.; LI, J.; FENG, G.; LIAO, Y.; HU, J. The effect of strontium-substituted hydroxyapatite coating on implant fixation in ovariectomized rats. Biomaterials, v. 31, n. 34, p. 9006-9014, 2010.

LI, Y.; SU, J.; MA, J.; YU, F.; PAN, D.; LI, R. A super-microporous zirconia-alumina nanomaterial with high thermal stability. Materials Letters, v. 136, p. 183-186, 2014.

LIM, Y. W.; KWON, S. Y.; SUN, D. H.; KIM, H. E.; KIM, Y. S. Enhanced cell integration to titanium alloy by surface treatment with microarc oxidation: a pilot study. Clinical Orthopaedics and Related Research ${ }^{\circledR}$, v. 467, n. 9, p. 2251-2258, 2009.

LIU, P.; CHEN, G.-F. Porous materials: processing and applications. Elsevier, 2014. ISBN 0124078370 . 
LIU, Q.; HUANG, S.; MATINLINNA, J. P.; CHEN, Z.; PAN, H. Insight into biological apatite: physiochemical properties and preparation approaches. BioMed research international, $v$. 2013, 2013.

LOBO, A. D. O. Obtenção de super-hidrofilicidade em nanotubos de carbono alinhados e sua aplicação como nanobiomaterial. 2011. Tese de Doutorado apresentada no programa de pósgraduação em Engenharia Aeronáutica e Mecânica do Instituto Tecnológico de Aeronáutica, 201

LOBO, A. O. Obtenção de super-hidrofilicidade em nanotubos de carbono alinhados e sua aplicação como nanobiomaterial. 2011. 209 p Tese de Doutorado Programa de Pósgraduação em Engenharia Aeronáutica e Mecânica, Instituto Tecnológico de Aeronáutica

LOBO, A. O.; ZANIN, H.; SIQUEIRA, I. A.; LEITE, N. C.; MARCIANO, F. R.; CORAT, E. J. Effect of ultrasound irradiation on the production of nHAp/MWCNT nanocomposites. Materials Science and Engineering: C, v. 33, n. 7, p. 4305-4312, 2013.

LUZ, G. M.; MANO, J. F. Mineralized structures in nature: examples and inspirations for the design of new composite materials and biomaterials. Composites science and technology, v. 70, n. 13, p. 1777-1788, 2010.

MAEDA, S. S.; LAZARETTI-CASTRO, M. An overview on the treatment of postmenopausal osteoporosis. Arquivos Brasileiros de Endocrinologia \& Metabologia, v. 58, n. 2, p. 162-171, 2014.

MANOSSO, M. K.; PALLONE, E.; CHINELATTO, A. L.; CHINELATTO, A. S. A. Two-steps sintering of alumina-zirconia ceramics. In: SALGADO, L. e AMBROZIO, F. (Ed.). Advanced Powder Technology Vii, v.660-661, 2010. p.819-825. (Materials Science Forum). ISBN 0255-5476.

MARIE, P.; AMMANN, P.; BOIVIN, G.; REY, C. Mechanisms of action and therapeutic potential of strontium in bone. Calcified tissue international, v. 69, n. 3, p. 121-129, 2001.

MARQUES, C. M. Relação entre microestrutura e desgaste erosivo a frio e a quente em materiais cerâmicos à base de alumina. 2006. 170p. (Tese de Doutorado). PPGEM, UNIVERSIDADE FEDERAL DO RIO GRANDE DO SUL, Porto Alegre - RS.

MARTIN, R. B. Determinants of the mechanical properties of bones. Journal of Biomechanics, v. 24, p. 79-88, 1991/01/01/ 1991.

MATHEW, M.; TAKAGI, S. Structures of Biological Minerals in. Journal of Research of the National Institute of Standards and Technology, v. 106, n. 6, 2001.

MCLEAN, J. W. Evolution of dental ceramics in the twentieth century. The Journal of Prosthetic Dentistry, v. 85, n. 1, p. 61-66, 2001. 
MISHIMA, F. D.; LOURO, L. H. L.; MOURA, F. N.; GOBBO, L. A.; PRADO DA SILVA, M. H. Hydroxyapatite scaffolds produced by hydrothermal deposition of monetite on polyurethane sponges substrates. Key Engineering Materials, v. 493, p. 820-825, 2012.

MONDAL, D.; SO-RA, S.; SARKAR, S. K.; MIN, Y. K.; YANG, H. M.; LEE, B. T. Fabrication of multilayer ZrO2-biphasic calcium phosphate-poly-caprolactone unidirectional channeled scaffold for bone tissue formation. Journal of biomaterials applications, v. 28, n. 3, p. 462472, 2013.

MOURA, F. N. Síntese e Caracterização de Recobrimentos de monetita e hidroxiapatita Parcialmente Substituída com Zinco. 2012. 105 p Tese (Doutorado em Engenharia de Materiais). Instituto Militar de Engenharia, Rio de Janeiro.

NIELSEN, S. P. The biological role of strontium. Bone, v. 35, n. 3, p. 583-588, 2004.

O'BRIEN, F. J. Biomaterials \& scaffolds for tissue engineering. Materials today, v. 14, n. 3, p. 88-95, 2011.

$\mathrm{OH}$, S. H.; PARK, I. K.; KIM, J. M.; LEE, J. H. In vitro and in vivo characteristics of PCL scaffolds with pore size gradient fabricated by a centrifugation method. Biomaterials, v. 28, n. 9, p. 1664-1671, 2007.

OLIVIER, V.; FAUCHEUX, N.; HARDOUIN, P. Biomaterial challenges and approaches to stem cell use in bone reconstructive surgery. Drug Discovery Today, v. 9, n. 18, p. 803-811, 2004.

ORÉFICE, R.; MANSUR, M. HS, Biomateriais: Fundamentos e Aplicações, ed. Médica, C., Rio de Janeiro, v. 538, 2006.

PARK, J. B.; BRONZINO, J. D. Biomaterials: principles and applications. crc press, 2002. ISBN 1420040030.

PAVINATO, V. P. Estudo da solubilidade de apatitas em meios de interesse biológico. 2012. 81p Dissertação (Mestrado em Química). Universidade Estadual Paulista, UNESP, Araraquara.

PERDIGAO, J.; PINTO, A. M.; MONTEIRO, R. C.; BRAZ FERNANDES, F. M.; LARANJEIRA, P.; VEIGA, J. P. Degradation of dental ZrO 2-based materials after hydrothermal fatigue. Part I: XRD, XRF, and FESEM analyses. Dental materials journal, v. 31, n. 2, p. 256-265, 2012.

PETIT, C.; MEILLE, S.; MAIRE, E.; TADIER, S.; ADRIEN, J. Mechanical behaviour of a $\beta$-TCP ceramic with a random porosity: Study of the fracture path with X-ray tomography. Journal of the european ceramic society, v. 36, n. 13, p. 3225-3233, 2016.

PIERRI, J. Caracterização do nanocompósito de $\mathrm{Al}_{2} \mathrm{O}_{3}$ com inclusões nanométricas de $\mathrm{ZrO}_{2}$ visando sua aplicação como reforço em próteses odontológicas de cerâmica livre de metal. 2008. (Dissertação de Mestrado em Ciência e Engenharia de Materiais). Ufscar, São CarlosSP. 
PIERRI, J.; PALLONE, E.; ROSLINDO, E.; TOMASI, R.; RIGO, E. Compósitos de $\mathrm{Al}_{2} \mathrm{O}_{3} / \mathrm{ZrO}_{2}$ recobertos com hidroxiapatita dopada com íons Ag. Cerâmica, p. 160-164, 2007.

PINTO, K. N.; TIM, C. R.; CROVACE, M. C.; MATSUMOTO, M. A.; PARIZOTTO, N. A.; ZANOTTO, E. D.; PEITL, O.; RENNO, A. C. Effects of biosilicate((R)) scaffolds and low-level laser therapy on the process of bone healing. Photomedicine and laser surgery, v. 31, n. 6, p. 252-60, Jun 2013.

QUERIDO, W.; CAMPOS, A. P.; FERREIRA, E. H. M.; SAN GIL, R. A.; ROSSI, A. M.; FARINA, M. Strontium ranelate changes the composition and crystal structure of the biological bone-like apatite produced in osteoblast cell cultures. Cell and tissue research, v. 357, n. 3, p. 793-801, 2014.

RAMALHO, E. G. Análise do comportamento mecânico de espumas cerâmicas a base de alumina obtidas pelo método da réplica. 2012. 104 (Tese de Doutorado). Centro de Tecnologia, UFRN, Natal-RN.

RAMBO, C.; MÜLLER, F.; MÜLLER, L.; SIEBER, H.; HOFMANN, I.; GREIL, P. Biomimetic apatite coating on biomorphous alumina scaffolds. Materials Science and Engineering: C, v. 26, n. 1, p. 92-99, 2006.

RATNER, B. D.; HOFFMAN, A. S.; SCHOEN, F. J.; LEMONS, J. E. Biomaterials science: an introduction to materials in medicine. Academic press, 2004. ISBN 008047036X.

REDDY, T. R.; PADMALATHA, K. S.; REDDY, S. L.; NISHIKAWA, H.; REDDY, T. E. G. U. Synthesis XRD TEM and Optical Absorption Spectroscopic Characterization of Copper Doped Nano Apatite. 2014.

REGINSTER, J.-Y.; BRUYÈRE, O.; SAWICKI, A.; ROCES-VARELA, A.; FARDELLONE, P.; ROBERTS, A.; DEVOGELAER, J.-P. Long-term treatment of postmenopausal osteoporosis with strontium ranelate: results at 8 years. Bone, v. 45, n. 6, p. 1059-1064, 2009.

REGINSTER, J.-Y.; SEEMAN, E.; DE VERNEJOUL, M.; ADAMI, S.; COMPSTON, J.; PHENEKOS, C.; DEVOGELAER, J.; CURIEL, M. D.; SAWICKI, A.; GOEMAERE, S. Strontium ranelate reduces the risk of nonvertebral fractures in postmenopausal women with osteoporosis: Treatment of Peripheral Osteoporosis (TROPOS) study. The journal of clinical endocrinology \& metabolism, v. 90, n. 5, p. 2816-2822, 2005.

SABREE, I.; GOUGH, J.; DERBY, B. Mechanical properties of porous ceramic scaffolds: influence of internal dimensions. Ceramics International, v. 41, n. 7, p. 8425-8432, 2015.

SAKKA, S.; AYED, F. B.; BOUAZIZ, J. Mechanical properties of biomaterials based on calcium phosphates and bioinert oxides for applications in biomedicine. INTECH Open Access Publisher, 2013. ISBN 9535110519.

SALINAS, A. J.; VALLET-REGÍ, M. Bioactive ceramics: from bone grafts to tissue engineering. RSC Advances, v. 3, n. 28, p. 11116-11131, 2013. 
SALVINI, V.; INNOCENTINI, M.; PANDOLFELLI, V. Influência das condições de processamento cerâmico na resistência mecânica e na permeabilidade dos filtros de Al. Cerâmica, v. 48, n. 307, p. 307, 2002.

SANTANA-MELO, G. F.; RODRIGUES, B. V.; DA SILVA, E.; RICCI, R.; MARCIANO, F. R.; WEBSTER, T. J.; VASCONCELLOS, L. M.; LOBO, A. O. Electrospun ultrathin PBAT/nHAp fibers influenced the in vitro and in vivo osteogenesis and improved the mechanical properties of neoformed bone. Colloids and Surfaces B: Biointerfaces, v. 155, p. 544-552, 2017.

SANTOS, K. H. F., J. A. ; PALLONE, E. M. J. A. ; NASCIMENTO, L. I. S. Tratamentos Químicos Superficiais com $\mathrm{H}_{3} \mathrm{PO}_{4}$ e $\mathrm{NaOH}$ em Nanocompósitos de $\mathrm{Al}_{2} \mathrm{O}_{3}-\mathrm{ZrO}_{2}$. Simpósio e $2^{\text {a Semana de }}$ Vivência em Engenharia e Ciência de Materiais. Pirassununga-SP 2015.

SANTOS, K. S. Biomateriais na Regeneração Óssea. 2011. p.40 (Dissertação de Mestrado). Escola de Veterinária e Zootecnia da Universidade Federal de Goiás, UFG, Goiânia.

SARKAR, D.; MOHAPATRA, D.; RAY, S.; BHATTACHARYYA, S.; ADAK, S.; MITRA, N. Nanostructured $\mathrm{Al}_{2} \mathrm{O}_{3}-\mathrm{ZrO}_{2}$ composite synthesized by sol-gel technique: powder processing and microstructure. Journal of Materials Science, v. 42, n. 5, p. 1847-1855, 2007.

SARTORI, T. A. I. D. C. Biocerâmicas porosas de alumina e de alumina-zircônia recobertas com fosfato de cálcio para implantes ósseos. 2015. 89 (Dissertação de Mestrado). Faculdade de Zootecnia e Engenharia de Alimentos, Universidade de São Paulo - USP, Pirassununga - SP.

SCHWARTZWALDER, K.; SOMERS, A. V. Method of making porous ceramic articles: Google Patents 1963.

SEPULVEDA, P.; BINNER, J. Processing of cellular ceramics by foaming and $<\mathrm{i}>$ in situ $</ \mathrm{i}>$ polymerisation of organic monomers. Journal of the European Ceramic Society, v. 19, n. 12, p. 2059-2066, 1999.

SEPÚLVEDA, P.; PANDOLFELLI, V.; ROGERO, S.; HIGA, O.; BRESSIANI, J. Hidroxiapatita porosa produzida através do gelcasting de espumas visando aplicações biomédicas. Cerâmica, v. 45, n. 296, p. 198-202, 1999.

SHAO, R.; QUAN, R.; ZHANG, L.; WEI, X.; YANG, D.; XIE, S. Porous hydroxyapatite bioceramics in bone tissue engineering: current uses and perspectives. Journal of the Ceramic Society of Japan, v. 123, n. 1433, p. 17-20, 2015.

SILVA, K. L. Obtenção de nanocompósitos de alumina-zircônia para aplicação como biomaterial. 2011. (Dissertação de mestrado). Unicamp, Campina-SP.

SIQUEIRA, I. A.; CORAT, M. A. F.; CAVALCANTI, B. D. N.; NETO, W. A. R.; MARTIN, A. A.; BRETAS, R. E. S.; MARCIANO, F. R.; LOBO, A. O. In vitro and in vivo studies of novel poly (D, L-lactic acid), superhydrophilic carbon nanotubes, and nanohydroxyapatite scaffolds for bone regeneration. ACS applied materials \& interfaces, v. 7, n. 18, p. 9385-9398, 2015. 
SIQUEIRA, I. A.; OLIVEIRA, C. A.; ZANIN, H.; GRINET, M. A.; GRANATO, A. E.; PORCIONATTO, M. A.; MARCIANO, F. R.; LOBO, A. O. Bioactivity behaviour of nano-hydroxyapatite/freestanding aligned carbon nanotube oxide composite. Journal of Materials Science: Materials in Medicine, v. 26, n. 2, p. 1-10, 2015.

SOON, G.; PINGGUAN-MURPHY, B.; LAI, K. W.; AKBAR, S. A. Review of zirconia-based bioceramic: Surface modification and cellular response. Ceramics International, v. 42, n. 11, p. 12543-12555, 2016.

SOUSA, E. O., F.S.; PANDOLFELLI, V.C. Produção e caracterização de espumas de alumina pelo processo gelcasting sem controle atmosférico. Cerâmica. v. 55: p. 151-156 p. 2009.

SOUZA, F. B. M. D. CARACTERIZAÇÃO DE CERÂMICAS POROSAS DE ALUMINA REFORÇADA COM ZIRCÔNIA PRODUZIDAS PELO MÉTODO DA RÉPLICA. 2008. 66 (Dissertação de Mestrado). Universidade Federal do Rio Grande do Norte, Natal-RN.

STEVENS, M. M. Biomaterials for bone tissue engineering. Materials Today, v. 11, n. 5, p. 1825, 2008.

STUDART, A. R.; GONZENBACH, U. T.; TERVOORT, E.; GAUCKLER, L. J. Processing Routes to Macroporous Ceramics: A Review. Journal of the American Ceramic Society, v. 89, n. 6, p. 1771-1789, 2006.

SURESHBABU, S.; KOMATH, M.; VARMA, H. In Situ Formation of Hydroxyapatite-Alpha Tricalcium Phosphate Biphasic Ceramics with Higher Strength and Bioactivity. Journal of the American Ceramic Society, v. 95, n. 3, p. 915-924, 2012.

TAVARES, C. Produção e caracterização de revestimentos nanoestruturados em multicamadas de TiAIN/Mo. . 2002. 198p, Tese (Doutorado). Universidade do Minho, Portugal

THAMARAISELVI, T. V.; RAJESWARI, S. Biological Evaluation of Bioceramic Materials - A Review. Trends in Biomaterials \& Artificial Organs, v. 18, p. 9-17, July 2004.

TORTORA, G. J.; DERRICKSON, B. Corpo Humano-: Fundamentos de Anatomia e Fisiologia. Artmed Editora, 2016. ISBN 8582713649.

TROMBINI, V.; PALLONE, E.; MUNIR, Z.; TOMASI, R. Spark plasma sintering (SPS) of Al2O3-ZrO2 nanocomposites. Cerâmica, v. 53, n. 325, p. 62-67, 2007.

UCHIDA, M.; KIM, H.-M.; MIYAJI, F.; KOKUBO, T.; NAKAMURA, T. Apatite formation on zirconium metal treated with aqueous $\mathrm{NaOH}$. Biomaterials, v. 23, n. 1, p. 313-317, 2002.

UCHIDA, M.; KIM, H. M.; KOKUBO, T.; NAWA, M.; ASANO, T.; TANAKA, K.; NAKAMURA, T. Apatite-forming ability of a zirconia/alumina nano-composite induced by chemical treatment. Journal of biomedical materials research, v. 60, n. 2, p. 277-282, 2002. 
VIEIRA, J. D. O. Recobrimento biomimético de HA dopado com Ag sobre superfície de Ticp. 2013. (Mestrado em Ciências). Escola de Engenharia de São Carlos;

Faculdade de Medicina de Ribeirão; Instituto de Química de São Carlos, Universidade de São Paulo, São Carlos.

VOLKMER, T. M. Obtenção e caracterização de hidroxiapatita porosa pelo método gel casting de espumas para uso como implantes, 2006. 2006. Dissertação (Mestrado em Engenharia)Escola de Engenharia, Universidade Federal do Rio Grande do Sul, Porto Alegre

WILLIAMS, D. F. On the nature of biomaterials. Biomaterials, v. 30, n. 30, p. 5897-5909, 2009. . There is no such thing as a biocompatible material. Biomaterials, v. 35, n. $38, p$. 10009-10014, 2014.

WORKMAN JR, J.; WEYER, L. Practical guide and spectral atlas for interpretive near-infrared spectroscopy. CRC Press, 2012. ISBN 1439875251.

XIONG, Z.; YAN, Y.; WANG, S.; ZHANG, R.; ZHANG, C. Fabrication of porous scaffolds for bone tissue engineering via low-temperature deposition. Scripta Materialia, v. 46, n. 11, p. 771776, 2002.

YAN, Y.; WANG, X.; PAN, Y.; LIU, H.; CHENG, J.; XIONG, Z.; LIN, F.; WU, R.; ZHANG, R.; LU, Q. Fabrication of viable tissue-engineered constructs with 3D cell-assembly technique. Biomaterials, v. 26, n. 29, p. 5864-5871, 2005.

YANG, S.-P.; LEE, T.-M.; LUI, T.-S. Biological response of Sr-containing coating with various surface treatments on titanium substrate for medical applications. Applied Surface Science, v. 346, p. 554-561, 2015.

ZANIN, H.; ROSA, C.; ELIAZ, N.; MAY, P.; MARCIANO, F.; LOBO, A. Assisted deposition of nanohydroxyapatite onto exfoliated carbon nanotube oxide scaffolds. Nanoscale, v. 7, n. 22, p. 10218-10232, 2015.

ZANIN, H.; ROSA, C. M.; ELIAZ, N.; MAY, P. W.; MARCIANO, F. R.; LOBO, A. O. Assisted deposition of nano-hydroxyapatite onto exfoliated carbon nanotube oxide scaffolds. Nanoscale, v. 7, n. 22, p. 10218-10232, 2015.

ZHU, X.; JIANG, D.; TAN, S. The control of slurry rheology in the processing of reticulated porous ceramics. Materials Research Bulletin, v. 37, n. 3, p. 541-553, 2002.

ZHU, X.; JIANG, D.; TAN, S.; ZHANG, Z. Improvement in the Strut Thickness of Reticulated Porous Ceramics. Journal of the American Ceramic Society, v. 84, n. 7, p. 1654-1656, 2001. 